Magalhães, Amilcar Armando

Botelho de

Relatorio apresentado ao $\mathrm{Sr}$.

Coronel Candido Mariano da

Silva Rondon 
F2515

. $M 3$

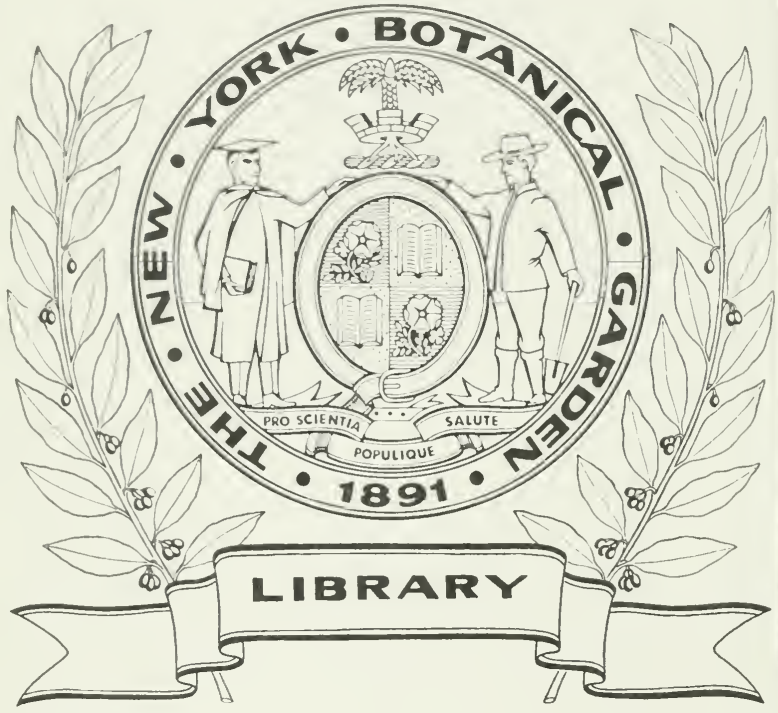




Expedição Scientifica RooseveIt-Rondon

\title{
ANNEXO N:5
}

\section{RELATORIO}

APRESENTADO AO

\section{Sin. Cononel Candido Mariano das silva Rondon}

Chefe da Commissão Brasileira

\author{
PELO \\ Capitão Amilcar Armando Botelho de Magalhães \\ Ajudante da Expedição
}

"बே.

RIO DE JANEIRO 

RELATORIO 



\section{Expedição Scientifica RooseveIt-Rondon}

\section{ANNEXO N:}

\section{RELATORIO}

APRESENTADO AO

\section{Sir. Cononel Candido Mariano da siliva Rondon Chefe da Commissão Brasileira}

PELO

Capitão Amilcap Armando Botelho de Magalhães

Ajudante da Expedição

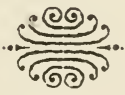

IRI() I) E . IANEIIRO 



\section{ERRATA}

PAGINA

LINHA

LEA-SE :

EM VEZ DE :

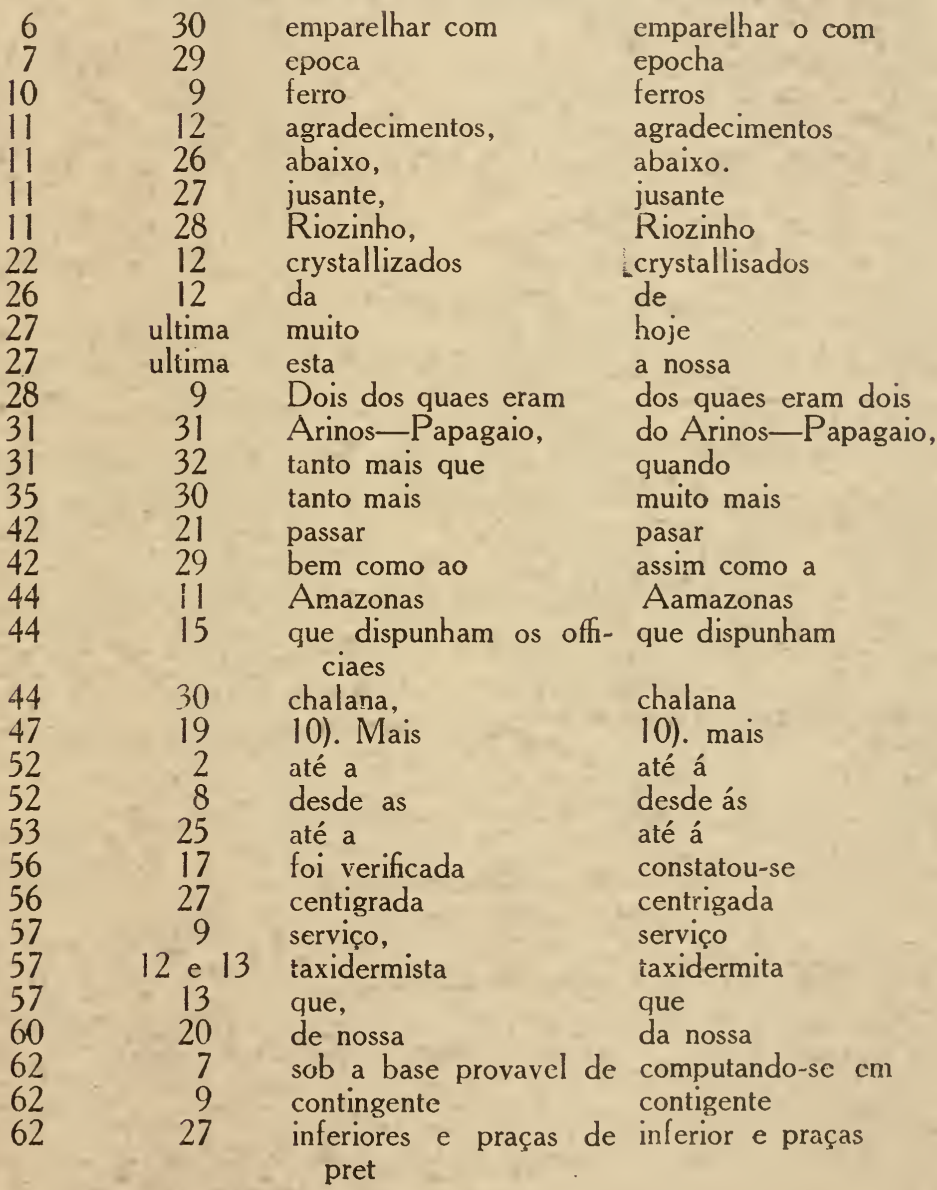




\begin{tabular}{|c|c|c|c|}
\hline GINA & LINIIA & LEA-SE • & EM VEZ DE: \\
\hline (1) & 22 & attribuo & atribuo \\
\hline 63 & 24 & contingente & contigente \\
\hline 64 & 15 & de vos relatar & de relatar-vos \\
\hline 65 & 25 & pessoal & pesc \\
\hline 66 & 17 & se espojarem & espojarem-se \\
\hline 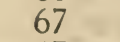 & 11 & sế & secco \\
\hline & 15 & r-se-iam & dever-se-ia \\
\hline 67 & 18 & ucção & condução \\
\hline & 18 & que não me & que me não \\
\hline 6 & 16 & sobre a & sobre á \\
\hline 69 & 19 & bé & $\mathrm{ca}$ \\
\hline 71 & $\begin{array}{r}21 \\
7\end{array}$ & amarrando & $\begin{array}{l}\text { bocca } \\
\text { por amarrar }\end{array}$ \\
\hline 72 & 26 & pelos animaes para & para \\
\hline 72 & 26 e 27 & estes de pé & os animaes de pé \\
\hline 7 & 23 & $\begin{array}{l}\text { a Gralhão, recebendo } \\
\text { outra }\end{array}$ & $\begin{array}{l}\text { em Gralhão receben } \\
\text { outro }\end{array}$ \\
\hline 75 & 29 & exemplo, & exemplo \\
\hline & $29 \mathrm{e}$ & atravessado sobre & atravessado, sobrc \\
\hline$\pi$ & 22 & $\begin{array}{l}\text { ou acima } d \\
\text { confundem }\end{array}$ & confudem \\
\hline & 21 & Ponte & Ponde \\
\hline & 17 & demonstrar & propoz-se a demor \\
\hline 70 & 32 & demonstrado & constatado \\
\hline & 25 & conjuncto, & conjuncto \\
\hline $\begin{array}{l}83 \\
84\end{array}$ & $\begin{array}{l}25 \\
15\end{array}$ & cerceadas & cercadas \\
\hline & 11 & $\mathrm{~s}$ & seca \\
\hline & 10 & só & еса \\
\hline & 12 & sêca & seca \\
\hline
\end{tabular}




\section{INTRODUCÇĀO}

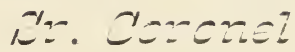

Por proposta vossa apresentada ao Sr. Ministro da Guerra, por intermedio do Sr. Ministro do Exte rior, aquella autoridade, em aviso de 14 de Outubro de I9I 3 ordenou a minha passagem á disposição do Ministerio da Viação como ajudante da Commissão de Linhas Telegraphicas Estrategicas de MattoGrosso ao Amazonas, para o fim especial de tomar parte na expedição que o Governo ö̆ganizaria, sob vossa chefia, com o objectivo de acompanhar o Sr. Theodore Roosevelt através do sertão do Brasil.

A 2 I desse mesmo mez apresentei-me por tal motivo ao escriptorio central daquella Commissão. afim de aguardar rossas ordens.

Dada a pressa com que era necessario conseguir os elementos indispensaveis á projectada travessia e de accordo com as ordens telegraphicas que transmittistes, quando em viagem de Manáos para o Rio de Janeiro, iniciei desde logo nesta Capital as providencias mais urgentes em relação á acquisição da munição de bocca, material de acampamento e instrumentos de engenharia, etc.. estabelecendo as 
condiçoes a que devia obedecer a respectiva embalagem, visto que o official indicado para o serviço de intendencia achava-se em Matto-Grosso, onde aguardava a passagem da expedição, sem tempo absolutamente de vir ao Rio de Janeiro. Assim é que em 25 de Novembro embarcavam nesta Capital alguns membros da Commissão Brasileira e com elles seguiam 22 I volumes de carga pertencente á Expedição que ficara designada officialmente com o titulo de Expedição Scientifica Roosevelt-Rondon.

O atrazo com que foi entregue parte do numerario destinado ás despesas da expedição, impedindo-vos de partir com os demais membros pelo ultimo paquete transatlantico que vos permittiria alcançar Corumbá antes da chegada ali do Sr. Roosevelt, determinou a viagem expressa por terra, do Rio de Janeiro ao rio Paraguay, utilisando-se para esse fim das vias ferreas Central do Brasil, Sorocabana e Noroeste, para cujo percurso era bem exiguo o tempo disponivel, muito mais quando nesta ultima havia cerca de 40 leguas de marcha a cavallo, além de um grande trecho apenas trafegado pelos trens de lastro.

A espectativa dessa viagem por terra deixavanos entrever claramente que nos submetteriamos a uma dura prova de resistencia sob as vossas vistas immediatas, mas não havia como fugir a uma tal situação e preparámos o espirito para subjugar as deficencias do vigor physico que em caso algum poderia emparelhar o com o vosso, por mais arrogante que fosse a nossa vaidade pessoal.

Assim desenhou-se a perspectiva do primeiro tributo que eu pagaria pela enorme distincção com 
que fôra abalada a minha modestia ao ser convidado para tomar parte nessa Expedição.

Cabe aqui o meu sincero reconhecimento pela vossa lembrança do meu nome para auxiliar tão delicados trabalhos e pedeis estar certo de que o meu desvanecimento na acceitação de tal convite só fôra possivel porque de envolta levava n'alma a certeza de que a influencia da vossa direcção nortearia a minha acção, não permittindo que eu succumbisse á pressão das minhas proprias falhas.

\section{CAPITULO I}

\section{Sob a vossa chefia immediata}

Em 2 de Dezembro desse mesmo anno, obedecendo a tão honrosa indicação parti em vossa companhia pelo nocturno de luxo; ás 2 I horas e 30 minutos do dia 3 chegámos a $\mathrm{S}$. Paulo com um atrazo de 2 horas e 20 minutos e ás 20 horas e I 3 minutos partimos pela Estrada de Ferro Sorocabana: ás Io horas e 30 minutos do dia 4 chegámos á estação Baurú onde nos aguardava um trem especial posto á vossa disposição; ás I I horas e 50 minutos partimos de Baurú e ás 2 I horas desembarcámos em Araçatuba, onde pernoitámos visto não estar em certo trecho consolidada a linha de modo a permittir que se viajasse á noute. Em caminho para Araçatuba fez-se uma pequena parada na estação provisoria "Heitor Legrue ", onde os indios Kai-gangs, esses mesmos considerados ferozes e cuja pacificação foi feita pessoalmente por vós em epocha bem recente. vieram documentar vivamente a injustiça de que 
(ram victimas, festejando a mossa passagem pelas slas terras.

A s 3 horas do dia 5 partimos para I tapura onde apenas demorámos 20 minutos: ás o horas desem larcámos na estação provisoria de Jupiá: A’s 12 horas desatracou o "fer-boot " conduzindo-nos para a margem direita do rio Paraná, o que vale dizer, transportando-nos do Estado de S. Paulo para o de Matto-(irosso.

Reorganizado o trem sobre os trilhos da outra margem, partimos ás 14 horas para 'Tres Lagôas onde almoçámos ás It horas e 30 minutos. A's i j horas e 30 minutos retomámos o trem e ás 20 horas c 30 minutos desembarcámos na estação de RioV'rde, ultima estação inaugurada nesse trecho e na qual fizemos a nossa segunda refeição. A's 5 horas de 6 partimos para a ponta dos trilhos: ás 8 horas saltámos do "wagon " e ás 9 horas e 30 minutos partimos montados da ponta dos trilhos com destino ao rio Pardo, onde apeámos ás 16 horas e 5 minutos. Em Rio Pardo onde ás Io horas fizemos a unica lefeição desse dia aguardámos a chegada da tropa, que só appareceu ás 22 horas, recebendo ordem vossa de proseguir viagem, substituindo-se alguns animaes cargueiros que davam mostras de cảnsaço. A's 2 horas do dia 7 iniciámos a nova marcha aproveitando a claridade das estrellas e ás io horas e I5 minutos apeámos junto ao corrego CampoAlegre onde tomámos a unica refeição desse dia; ás 16 horas e 10 minutos proseguimos viagem e no dia 8 ás 2 horas e 30 minutos apeámos em um sitio pertencente ao Coronel Sebastiãc de Lima, a uma legua de Campo-Grande, ahi pernoitando. 
As 8 horas e 35 minutos do mesmo dia dia 8 chegámos á villa de Campo-Grande, onde aguardámos a vinda dos cargueiros que conduziam nossa bagagem, o que só se deu ás i 3 horas. Nesse mesmo dia partimos ás i 8 horas e a I hora do dia 9 chegámos ao acampamento da construcção do outro trecho da Estrada de Ferro Noroeste. Ainda a 9, ás 6 horas e 15 minutos partiu o trem especial posto á nosse disposição para vos conduzir a PortoEsperança.

Adeante da villa de Aquidauana o trem parou alguns minutos, junto á estação provisoria "Visconde de Taunay ", onde um numeroso grupo de indios "Terenas", soltando foguetes e cantando na sua lingua, dava mostras do quanto os alegrava a rossa presença entre elles. Não me posso furtar ao dever de citar episodios como esse, visto envolver assumpto de tão grande interesse para a nossa Patria, ferindo o grande problema das relações do homem civilizado com o homem que habita as selvas. E é curioso assignalar, como nota probatoria do prestigio em que é tida a vossa pessôa entre elles. o facto de trazerem as mães os seus filhinhos recemnascidos para receberem o osculo affectuoso que lhes imprimieis, facto a que tambem se liga o sentimento affectivo do indio.

Desembarcámos ás 22 horas, em Porto Esperança, passando-nos com as nossas bagagens para bordo do paquete Nyoac, onde afinal a urgencia da marcha permittiu que fosse tomada uma refeiçâo nesse dia.

A's 23 horas e 30 minutos partia o Nyoac rio Paraguay abaixo com destino á foz do rio Ápa. No 


\section{0}

dia 10 ás + horas parámos defronte ao nosso legendario forte de Coimbra, glorioso baluarte da honra nacional, theatro de um choque armado da bravura paraguaya contra a bravura brasileira e onde se immortalizaram Portocarrero e o pequeno grupo de obscuros mas heroicos defensores da nossa Patria. A's 5 horas e 30 minutos proseguimos viagem à bordo do Nyoac e no dia I I ás 5 horas e 30 minutos arriámos ferros em frente a Porto Murtinho, pequeno povoado mattogrossense da margem esquerda do rio Paraguay.

De Porto Murtinho partimos ás $\delta$ horas e 5 minutos e ás 9 horas e 50 minutos encontrámos navegando contra nós o paquete "Brasil " de cujo bordo retirámos as nossas malas de fardamento fino, embarcadas no Rio de Janeiro conjunctamente com a carga destinada á Expedição, fazendo-nos ao larģo novamente ás io horas e 30 minutos.

Ancorámos ás I 3 horas e 30 minutos do dia I I, defronte á embocadura do rio Apa onde aguardámos a chegada do Sr. Roosevelt, olhando simultaneamente as terras brasileiras da sua margem direita e as terras paraguayas de sua margem esquerda. Nessa espectativa passámos a noite do dia i i, estabelecendo o serviço de vigilancia e conservando-nos de "promptidão " segundo a technologia militar. No dia I 2 ás Io horas e 40 minutos foi assignalada, a jusante, a fumaça de um navio no extremo do estirão em que nos encontravamos e ás I I horas e Io minutos ancorava a bombordo a canhoneira paraguaya "Adolpho Requielme ", em que viajava o Sr. Roosevelt. Após os cumprimentos do estylo, levados a bordo da "Riquielme ", partimos ás I 2 


\section{1}

horas e Io minutos comboiando com o Nyoac aquelle navio de guerra.

Durante o trajecto para Corumbá, a mais ampla cordialidade orientou a nossa acção relativamente ao ex-presidente e sua comitiva. No dia I 3 ás 9 horas e 15 minutos, ancorámos ao lado da canhoneira defronte ao forte Olympo, onde o governo do Paraguay mantem uma guarnição militar.

Em retribuição á visita que vos foi feita em nome do Sr. Coronel Crisostomo Machucas, commandante dessa guarnição, a este fui levar pessoalmente os agradecimentos apresentando-lhe os vossos cumprimentos cordialissimos, bem como os da Commissão Brasileira sob vossa chefia.

A's io horas e 45 minutos continuámos a subir o rio Paraguay, montando ás I 3 horas e 55 minutos a pyramide de base quadrada que, a poucos metros da margem direita, assignala os limites do Brasil com a Bolivia. A's I $_{5}$ horas parámos junto ao porto de Coimbra. No dia 15 ás 12 horas e 50 minutos passavamos pela povoação do Ladario e ás I 5 horas estavamos junto ás altas barrancas de Corumbá, onde ás 16 horas desembarcámos acompanhando a Commissão Americana á terra.

No dia I 7 ás 7 horas e 20 minutos partia 0 Nyoac rio Paraguay abaixo com destino ao rio Taquary, em cuja bocca de jusante denominada "Riozinho " penetrámos até o porto da fazenda das Palmeiras, atracando no mesmo dia ás ig horas e ahi pernoitando.

No dia 18 ás 7 horas e Io minutos partia a comitiva com destino á fazenda das Palmeiras, ahi apeando ás $\mathrm{I} 2$ horas e 40 minutos e tendo eu exe- 
cutado comvoseo o levantamento expedito da estrada percorrida, através do pantanal.

Desde o dia is até 23 de Dezembro esteve a Fixpedicão acantonada na referida fazenda, onde as commissões americana e brasileira adquiriram varias peças zoologicas para us museus respectivos de New-lork e. Rio de Janeiro. A 23, pelas i i horase I: minutos partiu a carreta conduzindo as bagagens "ás 14 horas e +5 minutos partiu a comitiva da Expedição através dos campos alagados, de regresso ao porto do Riozinho (braço do rio Taquary) onde reembarcou todo pessoal no paquete Nyoac, que ahi acuardava essa chegada. A 24, conforme ordem vossa fiz tripular uma canôa e iniciei ao clarear do dia o levantamento expedito do Riozinho desde o porto em que estavamos atracados, até slia fóz no rio Paraguay, tendo antes medido uma base de 600 metros á margem direita e percorrendo-a tres vezes a favor da corrente, procurando manter quanto possivel uma velocidade approximada da que empreQaria na descida, afim de avaliar convenientemente as relações de tempo e distancia vencida. A's 8 horas alcancei o rio Paraguay, concluindo ahi o levantamente e aguardando junto á margem esquerda a descida do paquete Nyoac, para cujo bordo passei ás 8 horas e 20 minutos, continuando a subir o rio Paraguay. Quatro horas depois passavamos pela segunda bocca do rio 'Taquary. A's i 4 horas estavamos montando o Paraguay-mirim, celebre pela passagem de tropas embarcadas, vindas de Cuyabá, sob o commando do General José Maria Coelho e que, graças á ligação desse braço de rio com o proprio curso do Paraguay acima de Corumbá, conse- 
guiram, com tal movimento retomar esta cidade das mãos do inimigo, ao tempo da guerra com o Paraguay. A’s 16 horas e 15 minutos passámos Ladario e ás I 7 horas atracavamos a Corumbá.

Cumprindo vossas determinações saltei em terra acompanhando a pessôa do Sr. Coronel Roosevelt, regressando ás I9 horas para bordo. A's 22 horas o Nyoac suspendeu ferro e seguimos em destino á fazenda de S. João, onde se encontrava S. Exa. o Sr. Presidente do Estado de Matto-Grosso com o fim de aguardar ahi a chegada do Sr. Coronel Roosevelt. No dia 26 ás 4 horas começámos a viajar em aguas do rio S. Lourenço e ás 2 I horas e I 5 minutos encetámos a subida do rio Cuyabá.

A's 20 horas e 30 minutos parámos defronte ao "Aterradinho ", pequena habitação á margem esquerda do rio Cuyabá, onde aguardámos o tempo sufficiente para que a chegada da Expedição á fazenda de $\mathrm{S}$. João não se verificasse durante a noite.

E' muito interessante assignalar que o terreno, justificando perfeitamente o nome dado a esse logar. é ahi constituido por camadas de aterro superpostas provavelmente pelos primitivos habitantes indigenas dessa zona. Justifica as hypotheses a excepção de qualidade e posição das terras nesse ponto, como em outras semelhantemente constituidas artificialmente, assim como a descoberta de fragmentos de objectos da ceramica elementar dos aborigenes, fragmentos esses encontrados nas excavações locaes.

A's 6 horas e 30 minutos de 28 partimos em direcção a S. João, onde chegámos ás 8 horas e 30 minutos. Ahi permaneceu a Expedição até o dia 30 , data em que partimos a bordo do Nyoac com destino 
ao ric S. Lourenço, cujo curso começámos a subir ás 1,3 horas e 30 minutos, afim de levar a effeito diversas caçadas em projecto.

Effectuadas estas, regressou o Nyoac a 2 de Janciro de I9I4, descendo o rio S. Lourenço e passando a subir o rio Paraguay ás Io horas e 15 minutos, em demanda de S. Luis de Caceres, onde chegámos ás 17 horas e 30 minutos do dia 5 do mesmo mez.

A's i 5 horas do dia 6 partiu o Nyoác, rio Paraguay acima, penetrando em seguida pelo curso do Sepotuba, e no dia seguinte ás I $_{5}$ horas e 45 minutos parava junto á fazenda do Porto do Campo, onde pela primeira vez foram armadas as barracas de (ampanha.

Da ordem do dia n. I, de $\bar{\gamma}$, publicada por vós cm Porto do Campo, dando organização definitiva aos diversos serviços da Expedição, consta a minha nomeação para exercer o cargo de secretario, na parte administrativa, assim como a incumbencia, na parte technica, dos serviços de meteorologia e topographia. Tendo que proseguir no mesmo dia com a maior parte do contingente, o seu respectivo commandante, assumi a $\boldsymbol{\gamma}$ de Janeiro as funcções de seu cargo em relação ao pessoal que ficou destacado nessa fazenda, como consta da ordem do dia n. I daquella data. Conforme as vossas ordens iniciei desde logo os trabalhos de preparação do acampamento em uma faixa do terreno de 100 por 200 metrus, dimensões do rectangulo capinado para esse fim na vargem da fazenda. Foram assim armadas I 4 barracas, duas de dupla cobertura, grandes, destinadas ao Sr. Coronel Roosevelt e a vós, occupando 
o centro do alinhamento cuja ala direita era constituida pela Commissão Americana, ficando a brasileira na ala esquerda, o que significa a collocação daquella no logar de honra, de accordo com as disposições dos nossos regulamentos em relação á precedencia militar, estabelecendo que se deve dar sempre a direita ao superior hierarchico.

Em frente ás duas barracas-chefe tremulavam respectivamente o pavilhão americano e o pavilhão brasileiro.

Nesse I. acampamento permanecemos até o dia I 3 , data em que ás I I horas partimos na lancha "Anjo da Ventura " e em uma chata a reboque, afim de proseguir o accesso do Sepotuba, em demanda de Tapirapoan, onde desembarcámos ás i I horas e 30 minutos de 16 e acampámos pela segunda vez. thi em Tapirapoan organizei, de accordo com as vossas instrucções as cargas que partiriam com as tres tropas que se destinavam á expedição do rio da Duvida e ao transporte de mercadorias e bagagens das duas turmas em que dividistes a expedição. Pelas i 8 horas de i 8 e pela madrugada de 19 sahiram os quatro lotes de tropa do rio da Duvida, com 54 bois cargueiros conduzindo i 36 volumes dos quaes 99 da Commissão Americana, 9 de barracas de campanha, um com as taboletas designativas dos rios Roosevelt e Kermit e 28 com generos destinados á alimentação do pessoal da tropa e com suas respectivas bagagens.

Convem dizer aqui, a proposito, duas palavras em relação a esses 99 volumes americanos :

Quasi todos elles eram constituidos de substancias alimenticias, acondicionadas de modo que a 
calda um dos dias da semana correspondia um certo menu, encerrado em pequenos caixotes dentro dos quaes estavam as conservas e petrechos divididos em duas caixas de zinco hermeticamente soldadas. Exteriormente viam-se inscriptos os $11 \mathrm{~s}$. 1 a 7 para assignalar os dias da semana de domingo a sabbado, respectivamente. Os caixotes continham assim almoço e jantar para dous dias, cada lata representando as duas refeições de um só dia para 8 homens, e eram calculadas de tal modo que a relação de peso e de volume determinaria a sua fluctuação se por acaso cahissem n'agua.

No dia 2 I pela manhã partiu a tropa de jt burros que conduziria as cargas de $1 .{ }^{a}$ turma sob a chefia de honra do Sr. Coronel Roosevelt. A's I 3 horas partia o pessoal technico da I . ${ }^{a}$ turma ao qual acompanhei até meia legua de distancia, retrocedendo então a Tapirapoan, depois de apresentar as minhas despedidas á Commissão Americana e demais membros componentes da primeira turma.

\section{CAPITULO II}

\section{Chefiando uma turma}

Regressando a Tapirapoan comecei desde logo a activar os preparativos de organização da minha turma, designada por "segunda " conforme fez publico a ordem do dia n. 2 , de 16 de Janeiro de rgi4.

Mandei immediatamente chamar á minha presença o encarregado geral das tropas de minha turma 
Antenor Rodrigues Gonçalves, e os arrieiros de cada uma das tropas, Pedro Augusto de Figueiredo, da de bois e João da Cruz Gomes da de burros, transmittindo-lhes ordens terminantes para que tudo estivesse prompto no dia seguinte.

Apesar, porém, dos meus esforços, só ás i6 horas de 22 partia o I. ${ }^{\circ}$ lote de ro bois cargueiros, sahindo o derradeiro lote de tropa ás r 8 horas e 30 minutos.

A tropa que servia ás necessidades da minha turma era constituida de 97 animaes quando sahi de Tapirapoan, sendo :

\section{Tropa dE BoIs}

Animaes cargueiros (mansos) . . 23

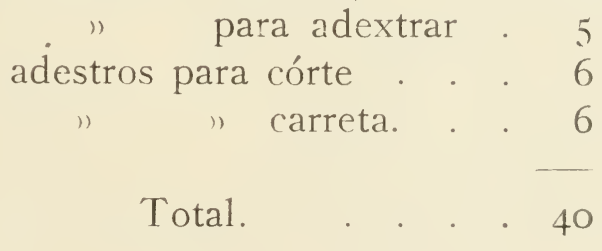

\section{Tropa de Muares}

Cavallo madrinha . Animaes cargueiros . . . . 40

" para montada de officiaes . I 2

" " campeio de gado. . 4

$$
\text { Total. . . . } 57
$$

Pouco antes da partida do I. ${ }^{\circ}$ lote de bois, partiram o tenente Reis (photographo e cinematographista) e o Sr. Hoehne (botanico) e pouco depois 
os taxidermistas Blake e Reinisch e o addido Joaquim Horta - todos com destino ao Salto. A's I 2 horas e 20 minutos sahiu o $\mathrm{I} .^{\circ}$ lote de burros com I I animaes e um tocador montado; ás 16 e 25 minutos o 2..$^{\circ}$ com outro tocador montado, ás I 7 horas e 25 minutos partiu o $3{ }^{\circ} \mathrm{com}$ I I animaes de cangalha e 2 tocadores montados e ás 17 horas e 45 minutos o ultimo lote de muares com uma mula adestra; ás I9 horas sahiu finalmente a derradeira fracção da tropa - o $2 .^{\circ}$ lote de bois cargueiros com I 3 animaes, tocando-se quasi ao mesmo tempo os I 7 bois adestros.

Do que foi o inicio da minha marcha no dia 22 a carta que vos dirigi em 25 do mesmo mez, fornece ideia aproximada (V. supplemento n. I ). Verificando pessoalmente a situação de todas as tropas e mandando descarregar um lote em meio do cerrado, para que os prejuizos fossem menores, retrocedi a Tapirapoan acompanhado do medico da turma Dr. Fernando Soledade e do Tenente Vieira de Mello, commandante do destacamento, combinando tudo de modo que ao clarear do dia seguinte pudessemos marchar com todas as tropas e concentral-as em Salto da Felicidade, ponto naturalmente eleito para primeiro pouso (24 kilometros de Tapirapoan). Assim aconteceu; ás 5 horas e 30 minutos do dia 23 estava sendo arriado o meu animal de montaria e em seguida partia eu acompanhado do Dr. Soledade deixando em Tapirapoan o Tenente Mello que fazia a retaguarda da columna para providenciar sobre o transporte, em carroça, de todas as cargas que fosse encontrando em caminho e que á beira da estrada seriam mandadas arrumar por mim. 
Taes cargas ahi collocadas indicariam não ter sido encontrado o animal cargueiro que as havia derrubado, na vespera, corcoveando.

A's 7 horas chegámos ao pouso do lote de burros que na vespera fizera acampar no cerrado e ahi esperei que terminassem os tropeiros os preparativos de marcha, assistindo ainda carregar os animaes, emquanto o Dr. Soledade proseguia viagem para o Salto da Felicidade.

A's 7 horas e 30 minutos puz-me em marcha escoltando o lote agora reduzido a 8 animaes, e ás 7 horas e 45 minutos encontrei a carga de um dos cargueiros desapparecidos, mandando desmontar um dos tocadores para utilizar a sua montada como cargueiro e fazendo distribuir por alguns dôbros as differentes peças de seu arreamento. A's I 3 horas alcancei o "Salto " com as tropas de bois e de burros que vim arrebanhando pela estrada, começando pessoalmente a dirigir a passagem te todas ellas e as cargas respectivas para a outra margem (direita) do Sepotuba, utilizando a balsa ahi existente. Durante esse tempo chegou de Tapirapoan o Tenente Mello e ás i 6 horas e 55 minutos tinhamos passado cargas e animaes para o outro lado, dirigindo-nos então ao rancho em que acantunavam os demais membros superiores da 2. ${ }^{2}$ turmâ.

Ao encontrar com esses companheiros é que fui ler com attenção a carta que vos dirigiram, solici. tando suas exonerações, documento esse que constitue o supplemento $n$. 2 e que agiu sobre o meu espirito como a mais formidavel das decepções que póde ter um homem no cumprimento de seus deveres. A pedido dos demissionarios fiz seguir um esta- 
feta montado levando um animal adestro, afim de conduzir a impatriotica e irritante missiva ao vosso acampamento que se encontrava a 57 kilometros além; o portador tinha ordem de regressar no dia immediato para o que viajaria dia e noite. A carta antipathica seguiu sem escolta de palavras minhas: nenhum commentario bordei ás idéas que continha aquelle verdadeiro auto-libello, para não influir absolutamente sobre o vosso julgamento, como tambem para não augmentar mais a aversão que despertaria em todos quantos viessem a ter conhecimento de seu conteudo.

Julgo porém aqui chegada a hora de respigar friamente esse documento, com a mais imparcial justiça. Antes que tudo, nenhum commentario se deve accrescentar ao facto de ter assignado a carta o Dr. Fernando Soledade, medico da turma, bastando para profligar semelhante acto, simplesmente relatal-o, expol-o assim nu aos olhos de todos. De accordo com a vossa ordem do dia n. 2 lida por mim no circulo de officiaes, quando a expedição se encontrava em Tapirapoan, foi o Dr. Soledade incluido na minha turma com as responsabilidades de medico, funcção essa de que se investiu, marchando em minha companhia de Tapirapoan ao Salto da Felicidade (24 kilometros). Compunha-se a minha turma nessa occasião de 56 figuras, sendo :

Pessoal technico e auxiliares (supplemento n. 3), 7 .

Contingente de praças do Exercito (supplemento n. 4), I6.

Encarregado, arrieiros e tropeiros (supplemento ns. 5 e 6$), 2$ I. 
Pessoal da tropa do rio da Duvida (supplemento n. 7), I 2 .

Teriamos que aggregar ao contingente mais um inferior e dez praças que se achavam em Aldeia Queimada; iriamos atravessar uma zona onde reinava o paludismo e estavamos tambem sujeitos evidentemente a todos os accidentes que se pódem produzir no sertão; não possuiamos nem pharmaceutico, nem um pratico que o substituisse; finalmente, apesar da expedição dispôr de um outro medico que acompanhava a I. ${ }^{a}$ turma, partiramos de Tapirapoan na convicção de que não tinhamos necessidade de pedir-lhe explicações sobre a utilização dos medicamentos mais essenciaes.

Foi nestas condições que a $2 .^{a}$ turma ficou privada de medico desde o segundo dia de marcha no sertão mato-grossense, chamado pelos proprios demissionarios " um dos mais aridos do Brasil ".

Quanto ao regresso dos demais membros e discutindo a atitude delles, em these, começaremos por analysar a primeira razão apresentada, pela qual se consideravam dispensados do encargo de acompanhar a turma, por haverdes constituido "uma 2. " expedição " com o fim de facilitar a locomoção por pequenos grupos. A insinuação só teria cabimento se fosse apresentada no momento mesmo em que tiveram conhecimento dessa divisão em turmas, o que não fizeram nem em seguida á leitura da respectiva ordem do dia, nem com a minima objecção depois da exposição verbal que lhes fizestes, desenvolvendo o assumpto, logo após essa leitura, quando ainda nos encontravamos em Tapirapoan. A allegação de que ao primeiro dia de marcha 
havia ficado em Tapirapoan parte dos mantimentos e hagagens indispensaveis á subsistencia da turma não deixando perder de vista o considerando feito mais abaixo e pelo qual se affirma que " ao mesmo tempo segue parallelamente uma commissão estrangeira melhor constituida de tropas e recursos» - deve ser traduzido do seguinte modo :

(a) Mantimentos indispensaveis significa ahi, não o feijão, a farinha de mandioca, o arroz, a carne fresca, as farinhas de aveia, o leite condensado, o café. o assucar, o sal, as cebolas, mas as conservas finas de peixe e fructas, os doces crystallisados da confeitaria Colombo, as latas de biscoutos da fabrica Jacob, o chocolate, as bolachas de agua e sal :

b) Bagagens indispensaveis deviam ser, na mesma proporção duplicatas de redes e mosquiteiros, sobresalentes de peças do vestuario, exagerada carga de munições de guerra e cartuchos para caça, superfluidades proprias de quem, desconhecendo o sertão, propunha-se a atravessal-o em condições de conforto relativamente opulentas.

Ao primeiro considerando referente ás necessidades de subsistencia e locomoção para o desempenho de suas differentes especialidades, direi que semelhante affirmativa seria irrisoria se não fôra insidiosa, porquanto, os primeiros animaes escalados para o serviço da turma o foram designadamente para attender ás exigencias da photographia, do taxidermista e do botanico, na conformidade das requisições apresentadas por cada um dos encarregados de taes serviços, a meu pedido, feito embora com a razoabilissima recommendação de que reduzissem ao minimo essa requisição. Quanto á sub- 
sistencia, linhas atrás ficou cabalmente demonstrado a que proporções se reduz, quando não faltou á turma genero algum de primeira necessidade, desde sua partida até o termo de sua viagem, apesar de eu haver cedido, parte dos generos que conduzia, á I. ${ }^{a}$ turma, por nos não fazerem falta.

O caminhamento parallelo de uma commissão estrangeira (da qual fazia parte o Chefe da Commissão Brasileira, o medico brasileiro, o nosso geologo nascido no Estado de Minas Geraes e mais dous officiaes do Exercito Brasileiro, em um total de 5 nacionaes para 8 norte-americanos) - " melhor constituida de tropas e recursos "), em primeiro logar deveria despertar da parte dos nossos compatriotas a lembrança das injuncções da hospitalidade, de comezinha obrigação moral para quem conhece os deveres de gentileza, sem falar nos deveres decorrentes da organização official da expedição; em segundo logar, desprezada a melhoria de "recursos ", em tudo eguaes aos que possuia a I. ${ }^{a}$ turma, sem contar com a munição de algumas iguarias mais finas em conserva, como já foi dito e justificado, teremos ainda a oppôr alguns algarismos para bem avaliar em que consiste a superioridade das tropas.

Sabido que a tropa do rio da Duvida foi constituida com o objectivo especial de conduzir de Tapirapoan ao rio da Duvida a carga de generos em conserva destinada á exploração projectada desse rio e confrontando o numero de animaes de que dispunha cada uma das turmas ao partir de Tapirapoan, teremos :
I. ${ }^{2}$ turma 89 .
2. turma 79 . 
Donde resulta para aquella turma um excesso de 10 animaes, compensado pelo facto de ser de 14 pessoas o seu estado-maior (mais 7 por conseguinte do que as da $2 .^{a}$ turma) e pela necessidade de fornecer uma segunda montada ao Sr. Coronel Roosevelt e dous animaes ainda, um para o ordenança do Sr. Roosevelt, outro para o do Sr. Coronel Rondon. E note-se que a $I{ }^{a}{ }^{a}$ turma tinha de conduzir recursos de bocca para um pessoal assim accrescido do seu estado-maior e dispunha além disso de 25 praças e 20 tropeiros num total de 45 homens, contra um total de 37 de que na mesma occasião dispunha a 2. ${ }^{a}$ turma.

Da presumida superioridade das tropas só resta provar que nem em qualidade a tropa da $2 .^{2}$ turma era inferior á da $\mathrm{I}^{\mathrm{a}}$, como o não era em quantidade. Ora, de todos os animaes empregados ahi para o transporte o mais resistente para essa zona é o bovino, em segundo logar o muar e em ultimo o cavallar; a $2 .^{a}$ turma possuia 23 bois cargueiros e a $1 .{ }^{a}$ nenhum; a $2 .^{a}$ turma dispunha de 56 muares cargueiros e de sella e a $I^{\circ}$ dispunha parallelamente de 66 animaes para o mesmo fim, sendo 5 cavallos.

Ainda quanto aos muares cargueiros e de sella, apesar de ser muito difficil determinar, em condições tão dissemelhantes, para que lado pendia essa superioridade, os supplementos 8 e 9 comparados com espirito amplamente neutral deixam claro que uma tropa valia bem a outra.

Finalmente, para completar esta dissecação, abordemos o ultimo considerando ageitado a martello e a facão nessa peça heterogenea.

Como em resistencia dos materiaes se calcula 
a que esforços de tracção ou de flexão póde ser submettida uma certa viga, o ultimo considerando tem a previsão mathematica da ruptura, como se o ser humano se devesse conformar unicamente com a força physica e relegasse a um plano secundario a influencia dos agentes de ordem moral. "Desairosa para a Commissão Brasileira e o que não ficou bem para o Brasil. " parece-me que foi justamente essa retirada precipitada do campo de batalha, só porque se teve noticias do inimigo. Mais desairosa ainda foi vêr quatro brasileiros regressando desalentados, ao mesmo tempo que o taxidermista Henrique Reinisch, austriaco, interrogado se desejava proseguir ou se acompanhava os desertores, declarava em seu mau português que "seguiria sempre para a frente, desde que houvesse feijão! " Nenhum argumento porém, a mais, se deve accrescentar, além da declaração de que a 2. ${ }^{a}$ turma da Expedição concluio a travessia Matto-Grosso-Amazonas, sem ter de lamentar os inconvenientes apontados nessa inconveniente missiva.

- Foi melhor talvez assim porque semelhantes tendencias dispersivas não se podiam afinar pelo nosso modo de encarar os serviços como esse. Segundo as velhas licções da experiencia, multiplicadas em tantos e tantos casos semelhantes aos vossos olhos, requer-se ahi uma grande harmonia de vistas, uma irmanação de sentimentos no convivio desses pequenos grupos, para que alguma cousa de util se faça e para que dessa união surja a força que annulla todas as difficuldades a vencer. Ainda nesse dia 23 mandei carnear o primeiro boi para o pessoal da turma. 
Ao cahir da tarde chegou com o campeador um dos quatro cargueiros extraviados n'essa primeira marcha; vinha em pello esse animal e nem fôra possivel encontrar-se a cangalha e tão pouco a carga de generos que transportava.

Communiquei á turma e dei ordem ao pessoal da tropa para a partida no dia immediato, o mais cedo possivel, mandando que permanecessem no Salto: um inferior, que aguardaria a volta do portador com a vossa resposta e levar-me-ia a ultima resolução dos demissionarios após sua leitura ; e um tocador de tropa de muares, incumbido de campear os tres animaes sumidos e marchar ao meu encontro.

Nessa marcha inicial perdeu-se um boi cargueiro que, tendo-se extraviado, foi depois encontrado morto no cerrado, presumindo-se que tenha sido victimado por mordedura de cobra, emquanto pastava.

No dia 24 de Janeiro ás 6 horas e 30 minutos partia a tropa de bois que foi cinematographada pelo Tenente Reis: ás 9 horas e 40 minutos sahiram os nossos bois adestros e os de córte; ás 9 horas e 55 minutos partiu a tropa de muares, dos quaes apenas foi destacado um para conduzir os petrechos de cozinha de ultima hora. A's io horas e 30 minutos após o almoço, que fôra distribuido uma hora antes, formou o pessoal e recebeu ordem de marcha com designação do pouso em "Kilometro Cincoenta ", partindo em seguida. Despedimo-nos dos ex-companheiros, agora considerados "desertores " e continuámos a cumprir o nosso dever.

Fazendo a retarguarda geral cheguei ás is 


\section{7}

horas e 30 minutos ao "Kilometro Cincoenta em cujos ranchos fizemos o nosso $2 .^{\circ}$ acantonamento.

Ahi encontrei o proprio que regressava do acampamento da I. ${ }^{a}$ turma.

Lendo a vossa correspondencia verifiquei que concedieis demissão a todos os signatarios da " celebre carta ", exceptuando o botanico Hoehne, na hypothese de acceitar este o estudo dos rios Papagaio e Sacre, sob o ponto de vista de sua especialidade (supplemento n. Io).

Reflectindo que esse convite não poderia ser acceito pelo Sr. Hoehne, tanto porque não se haviam mudado as condições de insuccesso que allegara para justificar o seu retrocesso, como tambem porque confessara a impossibilidade em que se encontrava de montar, resolvi não mandar voltar animaes para o ir buscar, dando-lhe sciencia por escripto dessa minha decisão.

Tal solução inspirada pelas circumstancias occasionaes, deixou-me entretanto preoccupado porquanto, vagamente, desenhava-se no meu pensamento a hypothese inverosimil do Sr. Hoehne acceitar aquelle offerecimento.

Tendo conhecimento do grande areal que separa o pouso de Kilometro Cincoenta do de Aldeia Queimada, dei as providencias necessarias, por intermedio do Tenente Vieira de Mello, commandante do contingente, para que as praças recebessem pela madrugada o almoço preparado e se puzessem em marcha immediatamente em direcção a este ponto.

Choveu hoje durante a nossa travessia. 


\section{8}

A's 5 horas e 30 minutos de 25 partiu o nosso contingente depois da distribuição do café e do almoço preparado. A' beira do fogo ficou o almoço dos officiaes para ser servido meia hora antes da partida da tropa de muares. Ainda para evitar o " areião ", partirá á tarde a tropa de bois.

A's 8 horas e 50 minutos almoçámos e em seguida tivemos a decepção de saber que faltavam 4 burros, dos quaes eram dous de sella.

A's 9 horas e 30 minutos foram encontrados os tres animaes e mandei deixar encostado ahi um delles que, por doente, estava evidentemente frouxo, em condições de não poder seguir viagem.

Parti á retaguarda do ultimo lote de burros ao meio dia, depois de ter-me assegurado pessoalmente de que não faltava nenhum dos nossos bois; a meio do caminho fiz seguir o Tenente Mello para a frente e aguardei a passagem da tropa de bois.

Entre as i6 e i 7 e meia horas trovejou e choveu copiosamente.

A's 2 I e meia horas, com uma das mais escuras noites que tenho visto no sertão, alcancei Aldeia Queimada com a cauda da columna e a corneta quebrou em seguida o silencio com os toques de rancho para officiaes e rancho para as praças. Acantonámos em uma esplendida casa que a Commissão de Linhas Telegraphicas tem ahi construida, acantonando tambem todo pessoal da turma nas outras casas existentes.

Ao amanhecer de 26 mandei ler as ordens do dia da Expedição a todo o conting̨ente que acom- 
panhava a turma até ahi e ao qual aggregou-se o destacamento de ro praças e um inferior que ahi aguardavam nossa passagem.

Sabendo, por informações, que Aldeia Queimada tem máo encosto para as tropas, adoptei medidas de previdencia e, da vigilancia exercida resultou, felizmente, que ao clarear do dia no pouso, pouco trabalho tiveram os campeadores para reunir todos os animaes, dos quaes deixei ahi um burro frouxo, tendo afrouxado tambem em caminho (em Apparição) um outro muar. Sendo curta a distancia de Aldeia Queimada ao rio Verde, onde iriamos pousar, mandei "rodear " o gado todo no pasto, recolhendo-o para arrear ao cahir da tarde.

A's I 3 e meia horas parti e ás I8 horas e 30 minutos cheguei com o ultimo cargueiro ao rio Verde, onde pela vez primeira a turma armou suas barracas-toldo.

Amanheceu aziago o dia 27 , verificando-se á chegada dos campeiros, a falta de 9 bois e 3 muares. Por ter na marcha de vespera alcançado o pouso com o seu lote desfalcado de um animal, sem que disso se apercebesse e como é esta falta a segunda do mesmo genero, que commette, tocando animaes com dia claro e em terreno de cerrado limpo, despedi hoje e fiz retroceder o tocador Manoel Pedro.

Por necessidades do serviço e procurando dar a cada um as funcções em que têm manifestado maior habilidade, determinei a transferencia de alguns tocadores da tropa de muares para a de bois e viceversa. Um delles - o tocador Varandas - não queria conformar-se com a sua passagem para a 
tropa de bois e pretendeu abandonar o serviço; resolvido embora a fazel-o proseguir á força, como consequencia perfeitamente justificavel das nossas condições de trabalho, consegui entretanto sob ameaça de suspensão do pagamento que the deviamos, conformal-o com a sua nova situação.

Certos detalhes como esse pareceriam de pouca importancia a um espirito superfluo, mas de facto realçam as contingencias em que se encontra quem assume a responsabilidade de qualquer trabalho no sertão e que se vê depender da vontade de homens inferiores, que comprehendem a dignidade pessoal sob aspecto tão deficiente e nos quaes é quasi nullo o sentimento de dedicação e solidariedade humana. Entre a desorganização do serviço por que é responsavel e o exercicio bem calculado da arbitrariedade, supponho que ninguem medianamente equilibrado vá escolher para seu uso a primeira das pontas desse dilemma.

Quando nesse mesmo dia 27 foram encontrados todos os animaes que faltavam e começou-se a carregar as tropas, cahiu um gelado e violento aguaceiro, de cuja existencia fizemos completa abstracção, passeando eu e o Tenente Mello, fóra da barraca, sem ponche, e fiscalizando o carregamento para não consentir que se molhassem as cargas: punhamos assim em pratica as vossas licções, dando em pessoa o exemplo da abnegação pelo serviço.

Viajando desde I I horas e 30 minutos, fui acampar no Ilio-Sê ás I 8 horas, atravessando mais essa area dos chapadões que aqui se succedem e se espalham em torno do nosso horizonte, semelhando 
o oceano, oceano de vegetação pequena, onde a vida animal é apenas representada por insectos.

No dia 28 ás 5 horas e 20 minutos consegui pôr os campeadores em actividade, mas verifiquei que havia rasto de animaes atravessando o Ilio-Sê, fugindo para trás, apesar de ter recommendado muito, na vespera, para impedil-o.

A's $\delta$ horas e 50 minutos seguiu o contingente a pé, conduzindo cada praça, como sempre, o seu " sacco de mala ", repositorio de todos os utensilios e roupas de que precisam ; ficaram apenas duas praças : o cozinheiro e o copeiro, as quaes seguirão após o almoço dos officiaes. Ao meio dia parti e ás I 3 horas attingi o rio Sacre, onde parei para examinar a tropa do rio da Duvida que ahi estava acampada com o inspector João de Deus. Essa tropa sahira nos dias i $\delta$ e ig de Tapirapoan, isto é, quatro dias antes da minha partida e eu a deixava agora á retaguarda. A's ig horas e 20 minutos cheguei á LagôaSecca, onde estava preparado o nosso acampamento para essa noite.

O exame do supplemento $n$. II deixa bem claro o itinerario e a marcha da minha turma.

Durante a ultima marcha acima referida apresentou-se-me o inferior que eu deixara em Tapirapoan e só então, lendo a carta que me dirigiu o Sr. Hoehne, verifiquei com satisfação que realmente estava elle de pleno accordo com a resolução que eu tomara de lhe não mandar animaes ao Salto, mostrando-se mesmo admirado da proposta que lhe fizestes para a exploração do Arinos-Papagaio, quando um dos motivos porque pedira exoneração residia na deficiencia do transporte. 
Lomo sabeis de 29 de Janeiro a 5 de Fevereiro, marchei diariamente, acampando sete vezes para dormir, a ultima das quaes á margem direita do ribeirão das Aldeias.

Para alcançar este ultimo pouso foi preciso que eu permanecesse em pessôa no acampamento anterior (Gralhão) até I 9 horas e 45 minutos, hora em que iniciei a marcha para frente, deixando apesar disso tres animaes perdidos e em seu encalço dous tocadores, pois que, ao toque de desarmar barracas, q!lando já se preparava o contigente para marchar, faltavam ainda 17 animaes da tropa.

Desta maneira alcancei o novo acampament: pela madrugada do dia 6 de Fevereiro ( 1 hora e 20 minutos), debaixo de forte aguaceiro, sendo obrigado a deixar varias cargas para trás durante o meu irajecto.

De tal modo ficou desorganizado o serviço de transporte que tive de ceder á imposição das circumstancias, permanecendo um dia no mesmo acampamento, e realizando dessa forma o ideal dos tropeiros que é de quando em vez "falhar " um dia para descançar.

Fiz entretanto seguir a tropa de bois e os bois adestros para Juruena, com ordem de regressar amanhã e conduzir o excesso de cargas produzida pelo afroixamento de io muares na marcha de Gralhão a ribeirão das Aldeias e neste ultimo logar, além do desapparecimento de 2 muares em Gralhão e dous bois no citado ribeirão -- perfazendo um total de 14 animaes cargueiros.

- No dia I 7 ás I 3 horas e 30 minutos parti 


\section{3}

do ribeirão das Aldeias, tambem chamado Taquarinha, fazendo a retaguarda do comboio, ao qual reuni os elementos que haviam ficado para trás na ultima marcha, mas deixando ahi, sob a vigilancia de dous homens as cargas que não havia possibilidade de transportar e que sel-o-iam, no dia immediato, por parte da tropa de bois que voltaria do Juruena para tal fim.

A's 20 horas attingi a estação telegraphica de Juruena e, aproveitando o luar, fiz transportar para a margem esquerda todas as cargas e cangalhas, com auxilio da balsa ahi mantida em serviço pela Commissão de Linhas Telegraphicas.

- Antes de chegar a Juruena, quando em marcha ainda para esta estação, destaquei um proprio para transmittir telegrammas, pedindo informações a respeito do estado em que se encontrava a estrada a percorrer dahi em deante, acompanhando a linha telegraphica construida. Tendo esse proprio attingido no dia 6 a estação, quando cheguei foramme apresentadas as respostas constantes dos supplementos ns. I2, I3, It e 15 , pelas quaes bem se podia ¿valiar o trabalho que teriamos a fazer para garantir o escoamento das duas columnas da Expedição por aquella estrada, desde Juruena até o rio da Duvida, sem interrupção de suas marchas.

Entretanto, como nobre incentivo, acabáramos de conseguir, á custa de perseverante esforço, a execução da I. ${ }^{a}$ parte do serviço que nos fôra designado, attingindo Juruena 24 horas antes da vossa turma. Com a vossa pratica de sertão, não tenho necessidade de detalhar quantas vezes estivemos em cheque dessa dolorosa perspectiva de alcançar tarde 
de mais aquelle ponto (ommum das nossas trajecto rias. Sob o dominio de taes pensamentos é que vos tracei a laconica communicação constante do supplemento 12.10 .

- A partir de Juruena teriamos, pois, conforme as vossas ordens além da responsabilidade de dirigir uma turma, mais a de concerter as pontes, pontilhões e estivados sem prejuizo da nossa marcha.

A' dedicada collaboracão do Tenente Vieira de Mello Filho eu devo o ter conseguido alcançar esse duplo objectivo.

Para a execução do serviço que agora nos incumbia, estabeleci uma divisão do contigente em duas turmas, cada qual dispondo de um inferior, revezando-se diariamente o pessoal no trabalho que competia a cada turma, sem prejudicar a escala mantida, desde a marcha inicial, de uma escolta á retaguarda do mesmo contingente.

A escolta compunha-se de um inferior e duas praças, cujo objectivo era compellir os retardatarios a completar a marcha sob sua vigilancia. Uma das turmas (a maior) era a do preparo da estrada, sob a direcção immediata do Tenente Mello e a outra, a do preparo do acampamento.

- Deixei em Juruena a tropa de bois que seguiria ao meu encontro quando viessem as cargas do ribeirão das Aldeias.

A's Io horas do dia 8 poz-se em marcha o contingente, depois de escaladas as turmas, tendo a de preparo de estrada estreado a poucos kilometros adeante, refazendo um estivado que se achava em 


\section{5}

más. condições. Demorando-me para assentar bem as ultimas providencias sobre o preparo de uma carreta que requisitei do commando do destacamento do Juruena, para meu serviço, só ás 13 horas e 50 minutos parti em demanda do rio Formiga, onde acampei com a minha turma ás 20 horas.

Por terem afrouxado successivamente dous muares que conduziam petrechos de cozinha, tardou nesse dia a distribuição do jantar, para o qual mandei carnear um dos nossos bois de corte, deixando assim de lado a carne em conservas de que nos temos servido ha alguns dias; ás I 3 horas terminámos essa refeição.

- Pousou commigo a tropa do rio da Duvida e combinámos o melhor meio de utilizarmos a balsa do rio Formiga, sem que haja atropelo e nem percamos tempo. Assim ao amanhecer do dia 29 fiz transportar toda a carga para a margem esquerda do rio e ás Io horas e 30 minutos começava a carregar a tropa de muares. A's I 2 e 30 minutos chegava ao Formiga a nossa tropa de bois reduzida agora a 2 I animaes; dando ordem para que descançassem ali e partissem a tarde para pousar no Juhina, onde o pasto está melhor, conforme informações que obtive, montei a essa hora e fui apear ás I 3 horas e 50 minutos á margem direita desse rio, providenciando em pessôa para que a balsa terminasse logo o seu moroso trabalho ; mandei passar a nado apenas os bois adestros, pois que muito esgotam os animaes cargueiros essas travessias, muito mais quando a tropa, resentida já de longas marchas através de uma zona mal dotada de pastagens está, em consequencia - mal alimentada. 
Tendo "varado " a tropa e as cargas por esse processo forçadamente vagaroso pois que essa balsa apenas supportava com segurança o peso de dous animaes de cada vez, com as respectivas cangalhas e consumia em média i m minutos para effectuar uma viagem "redonda "; ás 17 horas parti para o nosso $14 .^{\circ}$ acampamento no corrego do Urutáo onde cheguei ás 18 horas e 30 minutos.

- Como um forte temporal arrastára os estivados de ambas as margens do Juhina depois da nossa passagem e pela necessidade de desmontagem de nossa carreta, afim de tornar possivel seu transporte em balsa nos passos do Formiga e desse rio, mandei encostar toda a tropa em Urutáo, inclusive animaes de montaria, e dividi o contingente em tres partes proporcionaes aos trabalhos em mira.

I. $\left.{ }^{a}\right)$ turma sob a direcção de um inferior para reconstruir a ponte do Urutáo e respectivos estivados.

2. $\left.{ }^{a}\right)$ turma sob a direcção do Tenente Mello para reconstrucção dos estivados do rio Juhina.

$\left.3 .{ }^{a}\right)$ turma sob minha direcção com o objectivo de reconstruir os estivados mais proximos do rio Formiga e incumbir-se da trasladação da carreta e suas cargas.

- Essas turmas ao amanhecer do dia io deviam seguir a seus destinos, levando uma farofa de carne preparada para servir-lhes de almoço, do qual participariam os proprios officiaes.

Assim aconteceu, mas regressei do Formiga deixando entregue á I. ${ }^{a}$ turma a nossa carreta, conforme as vossas ultimas determinações, pois que, os 


\section{7}

generos que ella conduzia passariam á disposição dessa turma, visto não fazerem falta á nossa.

Ao passar pelo Juhina estava terminada a tarefa que fôra distribuida ao Tenente Mello e recolhemo-nos juntos ao acampamento do Urutáo, onde ainda occupámo-nos com a conclusão dos serviços ahi em andamento.

- Pela primeira vez consegui ver toda a nossa tropa reunida ás 7 horas e 30 minutos, sem faltar animal algum, de modo que no dia I i iniciámos muito mais cedo todos os serviços, conseguindo eu entrar no acampamento do Primavera, com a cauda da columna, ás I 4 horas e 30 minutos - facto este muito fóra do commum.

- No dia 2 ás 3 horas e 30 minutos fez uma das suas madrugadas, por ordem minha, a tropa de bois e ás 4 horas e 30 minutos partiu para a retaguarda um tocador de confiança levando dous bois cargueiros que iriam receber da carreta o nosso caixote de quinino, a banha e o café necessarios para attender ás necessidades da turma, por termos verificado a deficiencia desses generos.

- A ponte do rio Camararézinho deteve a nossa marcha, pois foi mister substituir-lhe uma das longarinas e recompol-a em muitos pontos; na impossibilidade de fazel-a nova, procurámos garantil-a para que resistisse á passagem das duas columnas de tropa, mas deixámol-a preocupados, como bem traduz a exposição feita no supplemento n. $I 7$.

A's 20 horas e 30 minutos acampei no "Chimarrão ", onde ás 23 horas sentámo-nos para jantar. 


\section{8}

Cintinuando sempre a deixar em cada marcha animaes frouxos e fazendo voltar tropa e tropeiros para ir buscar á retaguarda as carcas que iam deixando por força das circumstancias, cheguei a Campos-Novos ás 23 horas, quando então se recolheu no dia 13 a turma encarregada de concertos da estrada percorrida em nossa marcha desse dia.

Maiores detalhes da nossa marcha encontrareis no supplemento n. is, com informações do trajerto Juruena-Nhambiquaras.

- Ao passar pela estação telegraphica de Nhambiquaras recebi o vosso aviso cuja copia se encontra no supplemento n. I9, em termos lisongeiros para mim e com os quaes senti perfeitamente compensadas todas as tribulações com que era opprimido pelo meu temperamento, no desejo de bem servir, porque, além de minha consciencia, acabava de verificar através de vossas palavras, quanto em verdade comprehendieis o meu esforço e com que justiça encaraveis os meus actos.

Pouco depois de meio dia sahi no dia I 3 de Chimarrão, parando ligeiramente em MutumCavallo, onde estavam acampadas as tropas do rio da Duvida e a minha tropa de bois. afim de providenciar sobre o proseguimento de suas marchas, determinando-lhes o pouso em Campos Novos.

- Segundo as vossas ordens e apesar das ponderações que vos apresentei com a resposta constante do supplemento n. 20 deveria aguardar vossa chegada em Campos Novos. 


\section{9}

Como porém a ponte do rio I 2 de Outubro e varias outras, proximas delle, se achassem em pessimas condições, resolvi desde logo fazer seguir no dia seguinte o Tenente Mello com o contingente, afim de ir effectuando os reparos de que carecessem.

- Registemos de passagem que, em Campos Novos, junto á casa construida de telhas e tijolos fabricados ahi - com esquadrias de excellente madeiramento retirado da floresta proxima-existe um marco de madeira de lei, assignalando a data em que pela primeira vez a Commissão de Linhas Telegraphicas palmilhou esse terreno, sem que a houvesse precedido nenhum civilizado (20-VII909); além dessa data acha-se gravado mais o seguinte em uma das faces lavradas do marco:

\section{L. T. E. M.-G. A.}

Retiro da Invernada da Commissão.

Veado Branco.

Lat. S. $12^{\circ} 46^{\prime} 29^{\prime \prime}$.

Log. W. do Rio $6^{\circ} 50^{\prime}$.

- Os dias i4 e i5 passamol-os em Campos Novos onde nos viestes encontrar na tarde deste ultimo, tendo sido nesses dous dias concluido o preparo da estrada até o I 2 de Outubro, inclusive.

Havendo recebido vossas ordens pessoalmente, determinei para o dia seguinte o proseguimento de nossa marcha, de accordo com a norma sempre adoptada. 
A permanencia em Campos Noros onde ha pasto natural de primeira ordem revigorou a nossa tropa: além disso, porém. recebi ahi o reforço de 7 muares cargueiros que, se não estavam cm optimas condições, serviriam para revezar com os que já vinham mais enfraquecidos.

- A's 9 horas e 50 minutos de I 6 parti de Campos Novos fazendo a ponta da retaguarda da minha columna e de 16 a 20 marchei diariamente, executando sempre a reparação da estrada, passando a I 7 pela estação telegraphica de Vilhena e acampando no dia 20 na fazenda dos Tres Buritys.

Durante a marcha, apesar de se terem tornado imprestaveis para conduzir carga, mandei pacientemente tocar varios animaes afim de deixal-os nessa fazenda, onde o pasto de capim-gordura deveria restaurar-lhes as forças. E assim entreguei aos cuidados do encarregado da fazenda 26 cargueiros, dos quaes I 3 muares.

Para attender ás necessidades do meu transporte só precisei receber, em troca desses 26 animaes, 3 muares de montaria e Io bois cargueiros.

- De accordo com as vossas ordens fiz seguir na minha vanguarda a tropa do rio da Duvida, que deveria marchar, como a minha turma, até a cabeceira Sete de Setembro, onde acampariamos afim de aguardar a vossa passagem por ahi.

- Demorei-me em Tres Buritys no dia 2 I o tempo sufficiente para a reconstituição da tropa do rio da Duvida e das minhas tropas de muares e de bois, dando todas as providencias para a garantia da marcha dahi ao rio da Duvida, de fórmas que só pude montar ás $I_{5}$ horas e 45 minutos, para apear 
ás 2 I horas e 45 minutos na estação telegraphica de "José Bonifacio ".

Não tendo sido possivel á turma de preparo da estrada, pelo adeantado da hora, completar a limpeza da linha em trecho em que o mato difficilmente permittia a passagem, destaquei um inferior e quatro foiceiros para no dia seguinte retrocederem afim de executar esse serviço, terminado o qual deveriam apresentar-se no acampamento da cabeceira Sete de Setembro.

- No dia 22 assim se fez; ás 8 horas e 30 minutos partiu a turma de limpeza. A's 22 horas e 30 minutos sahi de José Bonifacio e ás I 5 horas e I 5 minutos cheguei ao nosso acampamento n. 22, junto á cabeceira Sete de Setembro, onde permaneci até o dia $2 \bar{\gamma}$, data em que prosegui minha marcha para a estação telegraphica Barão de Melgaço, emquanto que a I. ${ }^{a}$ turma, reduzida, iniciava a descida do rio da Duvida.

- No dia 23 marchou de Sete de Setembro para o Duvida o Tenente Mello, levando comsigo um inferior e I I praças, afim de completar ali o preparo das canôas que serviriam á exploração desse rio, em cuja margem esquerda acampou.

- Nos supplementos ns. 21 e 22 encontrareis, as informações que vos prestei por escripto nos dias 22 e 23 em relação a detalhes da minha marcha como ao modo pelo qual dei cumprimento a vossas ordens.

- A's I 4 horas do dia 24 recebi em meu acampamento o Sr. Coronel Roosevelt, seu filho Kermit Roosevelt, os naturalistas Miller e Cherrie, assim como os membros da Commissão Brasileira desta- 
rados na 1. turma. Mandei armar as suas barracas cm uma aréa já preparada por mim defronte ao meu acampamento, onde permaneceram até o almoço do dia immediato.

- No dia 2.5 aporós () almoço seguio o Sr. Coronel Roosevelt com sua comitiva para o rio da Duvida, em cuja margem direita acampou. A's i6 horas e 5.5 minutos o corneteiro do meu acampamento deu o signal de commando do 5. ${ }^{\circ}$ batalhão de engenharia, annunciando a vossa chegada ao meu acampamento, de onde parti comvosco para o acampamento do Duvida, ahi pernoitando por necessidade do serviço e regressando á cabeceira Sete de Setembro no dia 26 á tarde.

No dia 27 ás 7 horas e 30 minutos levantei acampamento da cabereira Sete de Setembro e fiz um grande alto no rio da Duvida, onde assistimos a vossa partida com a turma de exploração desse rio sob a chefia de honra do Sr. Coronel Roosevelt, partida realizada ás i 2 horas.

Ao pasar pelo vosso acampamento do Duvida recebi as bagagens e correspondencias que me confiastes para que as levasse a Manáos, entreguei relacionada a carga que deveria voltar para a estação José Bonifacio e, finalmente, aggreguei definitivamente ao meu estado-maior o naturalista americano Leo Miller e o geologo brasileiro Dr. Euzebio Paulo de Oliveira que commigo desceriam o rio $\mathrm{Gy}$ Paraná, assim como a meu contigente as praças e tropeiros constantes dos supplementos us. 23 e 24 , ficando assim a turma composta de 6 officiaes e 2 addidos, 76 praças e tropeiros, ao todo, pois, 84 homens. 


\section{3}

Em seguida á vossa partida levantou acampamento o Tenente Mello com o seu pessoal já novamente incorporado á minha turma e marchámos todos para a cabeceira Dr. Stiglmayr, onde acampei ás 20 horas.

- Desde que penetrámos na mata do rio da Duvida, a qual se liga á vasta floresta amazonense, tornou-se necessario introduzir um novo serviço para garantir a alimentação das tropas de muares e bovinos - a faxina para cortar palha de coqueiro. Só dessa maneira se consegue manter a tropa em condições de marcha e comprehende-se como é penosa semelhante maneira de viajar, na qual os nossos bois representam um papel semelhante ao dos camellos que atravessam os desertos africanos.

- Com duas marchas nos dias 28 e I de Março attingi finalmente a estação telegraphica Barão de Melgaço - termo da nossa jornada. - Conforme vossa recommendação organizei ahi as notas relativas a todo pessoal que havia tomado parte na Expedição, com designação do numero de dias de trabalho, turmas a que pertenceram etc., informando por telegramma ao Sr. Dr. Lauro Müller, Ministro do Exterior, sobre a partida da exploração do rio da Duvida e pessoal que me acompanharia (supplcmento n. 25).

- De conformidade com as vossas instrucções, teriamos que descer pelos rios Commemoração de Floriano, que passa junto á estação de Melgaço, Gy-Paraná ou Machado e Madeira, dirigindo-nos em seguida a Manáos, quanto ao itinerario. Quanto ao serviço de levantamentos, competia-me fazer o do Commemoração desde o passo "Parabens ", - - 
oilai a achoeira a montante de Melgaço; o do GyParaná desde o igarapé Bòa-Vista; os dos affluentes do) Gy-Paraná: Anary, Machadinho e Preto, até unde fosse relativamente facil subir com as canôas.

No emtanto ao abeirar-me do Commemoração ahi não encontrei os recursos que esperavamos para essa navegação fluvial, o que motivou a carta (supplemento n. 26) dirigida ao Tenente Aureliano Lima de Moraes Coutinho, chefe do acampamento da Commissão de Linhas Telegraphicas Estrategicas de Matto-Grosso ao Aamazonas, na parte da construcção a cargo da Secção do Sul.

- Attendendo á minha requisição, subiram do acampamento da construcção as duas embarcações de que dispunham: uma chalana e um batelão. Como, porém, deveria eu demorar-me cerca de uma semana acima de Melgaço, resolvi deixar a turma ahi e subir com o geologo Dr. Euzebio de Oliveira até o passo Parabens, de onde partiria de regresso, com o meu levantamento.

Nesse intervallo haveria tempo de apparecer o outro batelão, esperado em Melgaço a todo momento, pelo que, fiz descer, no que ahi estava, o inspector João de Deus e pessoal que devia recolher-se aos trabalhos da Commissão Telegraphica.

Mandei retirar do fundo do rio Francisco Bueno uma ubá pequena que, com a ajuda de feixes de taquarussú secco conseguimos que fosse tripulada por dous homens: com esta, destinada á conducção da mira e com a chalana preparei-me para subir o rio Commemoração de Floriano.

- No dia 4 de Março ás 8 horas e 50 minutos 
partimos de Barão de Melgaç̧o com as duas canôas de levantamento, fazendo-me conduzir bem como ao Dr. Euzebio na maior das embarcações. Com difficuldade conseguimos vencer a grande correnteza do rio Commemoração, cujo accesso só fôra possivel com a convergencia de esforços dos remos, de duas "zingas " e de um croque.

Infelizmente concorria muito tambem para essa difficuldade o pouco adextramento do pessoal, coincidindo que em uma turma de 45 praças e voluntarios regionaes, apenas conhecessem o serviço de remo e canôa, dous homens, um só dos quaes sabia nadar.

Antes que houvessem adquirido a pratica conveniente á custa da lentidão e dos perigos a que nos expunhamos, quiz a fatalidades que se "alagasse " a nossa chalana, quasi victimando o geologo e o pessoal que a tripulava, no numero dos quaes apenas um (!) sabia nadar. Dadas as providencias para salvamento do pessoal, resolvi seguir só, tripulando com menor numero de homens a chalana e reduzindo a um terço os nossos generos. Uma circumstancia impediu ainda este segundo projecto: o mergulho da canôa deixara-nos sem o croque e reduzira-nos a tres remos dos nove que traziamos.

Não fôra a espera a que sujeitariamos o nosso hospede norte-americano, que sempre foi por nós considerado como um representante do Coronel Roosevelt, mandaria fazer os remos de que necessitavamos; urgia porém resolver com rapidez maior e, regressando por terra á estação de Melgaço, expedi um proprio levando a carta urgente que agora figura no supplemento n. 27. 
A requisição desse batelão, não só attenderia á impaciencia demonstrada pelo naturalista americano de descer immediatamente, como tambem trar-me-ia o numero de remos de que necessitava para mais uma vez tentar o cumprimento de vossa ordem em relação ao levantamento do Commemoração a partir do passo Parabens. A resposta ao portador não se fez esperar e desfazia por completo a esperança que alimentaramos. Immediatamente aprestei-me para descer o rio, já que o não podia subir, e iniciar dahi o seu levantamento. embora houvesse que deixar retidos, em Barão de Melgaço, os naturalistas e o pessoal que não fosse necessario ao meu serviço. Julgava tambem que tal resolução estaria de accordo com o desejo varias vezes manifestado pelo naturalista Miller de demorar-se alguns dias em ponto conveniente que lhe facilitasse 0 enriquecimento das suas já importantes collecções de animaes. Infelizmente a pesar da riqueza da fauna no valle do rio Commemoração, a caça não foi abundante e o projectado beneficio transformou-se em contrariedades para o nosso hospede, como se evidencia do seguinte telegramma que expediu para Manáos :

"Theodore Roosevelt. Delayed at Baron Melgaço waiting for canoes, nothing here but rain, sickness and mosquitoes. Leo E. Miller. "

Cuja traducção é ao pé da letra:

"Theodoro Roosevelt. Detido em Barão de Melgaço esperando canôas, aqui nada a não ser chuva, doenças e mosquitos. ")

- Nesse dia cheguei ás i 6 horas com o levantamento ao porto da "Jararaca ", que dá accesso ao 
actual acampamento da construcção da linha telegraphica, permanecendo ahi até o dia 5, em que, pelas $\boldsymbol{i}$ horas prosegui com o levantamento do rio.

Com I 27 estações acampei á margem esquerda do Commemoração, bemdizendo o sol que nos aquecera durante o dia.

- Prosegui com o mesmo serviço diariamente, alcançando Pimenta Bueno ás 10 horas de 8 e completando o levantamento do rio "Commemoração de Floriano " desde o passo da linha telegraphica até a sua fóz no rio Pimenta Bueno, de cuja confluencia resulta o rio Gy-Paraná ou Machado.

- No dia 6 pelas 9 horas encontrei navegando aguas acima o batelão que iria até Barão de Melgaço afim de receber o resto do pessoal da minha turma; ao piloto transmitti ordens severas para accelerar a sua marcha, fixando-lhe o prazo em que deveria attingir o termo de sua viagem para montante (dia Io) ; mais tarde soube que realmente foram cumpridas taes ordens, pois a I I de Março sahiu esse batelão de Melgaço, que na vespera attingira.

- No dia 8 encontrei o batelão que descera de Juruena no dia 4 , recommendando tambem ao respectivo piloto apressar a subida, tanto quanto possivel.

- Em Pimenta Bueno demorei-me até completar as providencias necessarias para organizar a minha nova turma de levantamento de rio e para ahi deixar os elementos de que careceriam os demais membros da turma com o fim de se conduzirem ao rio Madeira.

De conformidade com as instrucções que deta- 
lhastes em vossa ordem do dia n. I I de 26 de Fevereiro, publicada nas margens do rio da Duvida, competia-me realizar ainda o levantamento do rio (ị-Paraná desde o igarapé Bôa Vista até sua fóz no Madeira, como tambem o de seus affluentes Anary, Machadinho e Preto, devendo subir estes tres ultimos até o ponto em que permittissem a navegação de canôas grandes.

- Deixando pois ao Tenente Vieira de Mello as instrucções e communicações constantes do supplemento n. 28, parti no dia Io de Março, ás io horas, com destino ao igarapé Bôa Vista, onde desembarquei ás 9 horas do dia I2, ahi almoçando e preparando em seguinda as minhas tres canôas de levantamento: uma da cozinha, outra da mira e outra minha, com os instrumentos necessarios ao serviço.

Ao meio dia parti com o levantamento e apesar de ser muito encachoeirado nesse trecho o rio, consegui fazer ás i 8 horas e 30 minutos a minha centesima e ultima estação.

- Continuando o levantamento do rio GyParaná a favor de suas aguas, tive a infelicidade de naufragar pela 2. ${ }^{a}$ vez, no dia 15 ás 14 horas. Resolvi então descer para Monte Christo, barracão a jusante do naufragio, afim de refazer-me de recursos e ir novamente ao barracão de Bôa Vista onde constava a existencia de instrumentos que serviriam para proseguir nesse levantamento. O supplemento $n .29$ resume os trabalhos executados desde Melgaço até a minha chegada ao barracão Monte Christo, e tambem refere detalhes de viagem; assim como o supplemento n. 30 vos communica a 
improficuidade dos meus esforços para obter noros instrumentos de trabalho.

- No dia 17 quando retrocedi de Monte Christo, passei pelo batelão em que vinha o resto da turma e transmitti as ultimas recommendações ao Tenente Vieira de Mello, despedindo-me de nosso hospede - o naturalista Miller - e dos demais companheiros da turma, cuja direcção entreguei ao Tenente Vieira de Mello.

- Examinando a parte do levantamento que foi aproveitada porque estava desenhada já, verifiquei o ponto do rio em que ficara esse levantamento e no dia 22 apontava-o ao pessoal encarregado da canoa da mira, o qual desceria dahi novamente á barraca Monte Carlo, onde mandara ficar a canoa da cozinha com os respectivos empregados. Todos aguardariam alli a minha volta de Bôa Vista. Calculando a viagem, determinei ao pessoal da mira dia e hora em que deveriam esperar no ponto de amarração.

A's I 2 horas e 35 minutos do dia 2 I cheguei ao igarapé Bôa Vista, verificando a inutilidade do meu esforço por me não servirem os instrumentos que ahi estavam. A's I 5 horas parti de Bôa Vista e ás I 7 horas encontrava a canoa da mira com a qual recolhi-me a Monte Carlo, onde afinal ficou novamente reunida a minha turma de levantamento, agora reduzida a uma simples turma de " baixada ".

Continuando a descer no dia seguinte, cheguei a Monte Christo ás I 3 horas e 45 minutos desse dia 22, gastando 6 horas e 28 minutos para o mesmo trajecto que, de subida, exigio-nos 30 horas de via- 
yem continuada, descontando o tempo consumido nas diversas paradas para comer e dormir.

Informaram-me então de que o resto de minha turma partira de Monte Christo no dia 19 após o almoço e que poderia pois attingir Manáos de 28 a 3 de Março.

De Monte ('hristo a Calama do rio Madeira utilizámos os meios de transporte de que dispõe ahi a firma Asensi \& C. concessionaria de seringaes nessa zona.

Parti ás 6 horas e 15 minutos de Monte Christo no dia 24 a bordo da lancha "Jackal " a cujo costado ia atracado um grande batelão com alta cobertura de zinco, como um barracão fluctuante; ás 7 horas cheguei á bocca do Jarú (cachoeira Idalina) onde a casa Monteiro dispõe de um barracão á margem esquerda do Gy; ás 9 horas e Io minutos passámos S. Sebastião, porto tambem da casa Monteiro; ás 14 horas e 50 minutos desembarquei em S. José, onde pernoitei.

No dia 25 ás 7 horas e 20 minutos partimos de $\mathrm{S}$. José em um batelão para passar á margem opposta (esquerda) visto estar intransitavel o varadouro por terra, desembarcando ás 7 horas e 30 minutos em uma ilha existente a montante da cachoeira S. José ; atravessando a pé a pequena ilha tomámos uma chalana com que fomos conduzidos, através da corredeira que envolve a ilha, para jusante da cachoeira, atracando proximo ao barracão S. Felix (casa Monteiro) a montante da cachoeira do mesmo nome. Neste ultimo ponto aguardámos a chegada da outra lancha que faz o serviço no trecho S. Felix 
- Tabajara e no dia 26 ás 8 horas e Io minutos, partimos como passageiro da "Boadicéa ".

A’s I I horas e 50 minutos passámos por Assumpção, ponto do I. ${ }^{\circ}$ barracão da casa Monteiro para quem sobe o rio; pelas i 5 horas passámos a bocca do rio Machadinho, affluente do Gy pela margem esquerda; ás 16 horas e 30 minutos atracámos ao barracão Maruim (synonymo de mosquitopolvora) e ahi pernoitámos.

- No dia 27 ás 6 horas partimos de Maruim na mesma lancha Boadicéa e ás 8 horas chegámos a Tabajara.

- A 28 descemos em uma chalana até a barraca "Remanso ", onde desembarcámos ás 7 horas e 30 minutos depois de uma hora de viagem, partindo dahi a cavallo ás - horas e 45 minutos para apear ás 9 horas e 30 minutos, a legua e meia de Remanso, em Cachoeirinha, através do varadouro aberto ao trafego entre esses dous pontos.

Em Cachoeirinha tomámos a lancha " 24 de Junho " e ás Io horas e 5 minutos desembarcavamos em S. Vicente, outra cachoeira, de onde, montado, transportei-me para a ultima cachoeira "Dous de Novembro ", alcançada ás Io horas e 45 minutos.

- No dia 30, ás 15 horas e 50 minutos, sahi de "Dous de Novembro " a bordo da lancha "Diana ". Só nesse dia deixámos de viajar em territorio matto-grossense para penetrar em terras amazonenses, pois que a jusante dessa ultima cachoeira é que está o marco divisorio que assignala os limites de Matto-Grosso e Amazonas pelo parallelo de $8^{\circ} 4^{8^{\prime}}$ de latitude Sul. 
No dia 3 I de Março ás I I horas e 20 minutos atracámos a Calama, onde permaneci até á passagem do I. "vaporzinho (gaiola) que dahi desceu em busca de Manáos.

No dia 2 ás I I horas e 30 minutos, sahi de (alama, descendo o rio Madeira a bordo do "Rio Curuçá " e subindo depois o rio Amazonas, desde ás 2 I horas e 50 minutos do dia 5, chegámos a Manáos pelas I I horas do dia 6 de Abril.

Sabendo que já havia chegado a Manáos a turma de exploração do rio Papagaio, visitei " in-continenti ", o americano Fiala, ao qual apresentei parabens pela travessia que realizou.

No dia io pela manhã fui receber a bordo os demais companheiros de minha turma, conduzindo o Sr. Miller para o mesmo hotel em que se encontrava hospedado o seu compatriota Fiala.

- Logo á minha chegada a Manáos transmitti ao Sr. Ministro do Exterior o telegramma constante do supplemento $n$. $3 I$, e a vós as informações constantes do supplemento $n .32$.

- Emquanto pernoitei em Manáos procurei representar a Expedição junto a S. Ex. o Sr. Dr. Jonathas Pedrosa, Governador do Estado, assim como perante as demais auctoridades estadoaes e federaes, dispondo as cousas de modo a que em nada destoasse a hospitalidade amazonense de toda a que foi offerecida á Commissão Americana nos demais Estados do Brasil.

- E cumprindo vossas ordens parti no dia I 2 de Abril para o Rio de Janeiro acompanhado do 
geologo Dr. Euzebio de Oliveira, do 2. 'Tenente Vieira de Mello, commandante do contigente e do taxidermista Reinisch, no mesmo dia em que partia para New-York o Sr. Antony Fiala, da Commissão Americana; deixando em Manáos o 2. Tenente Alcides Lauriodó de Sant'Anna, representante da Commissão Brasileira e o Sr. Len Miller, representante da Commissão Americana.

Os supplementos us. 33, 37 e 35, registam finalmente as minhas despedidas apresentadas, por cartas que deixei em Manáos, ao Sr. Coronel Theodore Roosevelt; a vós; e aos membros da Commissão Americana, por intermedio do Sr. Kermit Roosevelt.

\section{CAPITULO III}

\section{Serviços de levantamento}

Por ordem vossa logo que cheguei ao Rio de Janeiro fiz entrega ao Escriptorio Central da Commissão de Linhas Telegraphicas Estrategicas de Matto-Grosso ao Amazonas das cadernetas em original e das differentes folhas dos "croquis" desenhados por mim, comprehendendo os seguintes levantamentos:

a) Levantamento expedito do caminhamento percorrido desde o porto do Riozinho até á Fazenda das Palmeiras, executado por vós com o meu concurso (supplemento n. 36 ).

b) Levantamento expedito do Riozinho (braço do rio Taquary) desde o porto da Fazenda das 
Palmeiras até sua foz no rio Paraguay, executado por mim, (supplemento n. 37).

c) Levantamento topographico do rio Commoração de Floriano desde o passo da linha telegraphica até sua confluencia com o rio Pimenta Bueno, executado por mim, (supplemento n. 38 ).

d) Levantamento topographico do rio GyParaná desde o igarapé Bôa Vista (até onde tinha sido já levantado por engenheiro da Commissão de Linhas Telegraphicas Estrategicas de MattoGrosso ao Amazonas) a proximidades do igarapé Riachuelo, no ponto até onde fôra desenhado o serviço quando naufraguei no estirão do Mereçal executado por mim (supplemento n. 39).

\section{CAPITULO IV}

\section{Observações meteorologicas}

Infelizmente a caderneta de observações meteorologicas e os respectivos instrumentos foram inutilizados com o naufragio que interrompeu o levantamento do rio Gy-Paraná.

Conforme publicastes em ordem do dia da Expedição delimitando as funcções de cada um dos membros da Commissão Brasileira, cumpria-me registar as observações meteorologicas, iniciando esse serviço em Tapirapoan. Aproveitando a demora de uma semana nesse logar, fiz uma série de observações, com leituras do barometro compensado, comparadas com as do barometro Fortin que ahi 
possuiamos, o que me permittiu determinar com certa precisão as differenças de leitura do aneroide para o padrão, além de estabelecer a curva daquelle, em funcção da variação normal da pressão barometrica nas differentes horas do dia.

- As observações thermometricas eram feitas simultaneamente ás leituras do barometro, além das duas leituras do thermometro de maxima e minima, uma ao clarear do dia e outra ao cahir da tarde, apurando-se assim a maxima á sombra durante o dia e a minima da madrugada. Como a Expedição se deslocava diariamente, o que evidentemente reduzia o alcance util de taes observações, visto que annullava a possibilidade de tomar uma série dellas sobre o mesmo ponto, tornava-se tambem por outro lado difficil determinar a temperatura maxima durante o dia. Para resolver esta difficuldade submetti os dous thermometros de maxima e minima a uma série de comparações, conservando um delles dentro de casa em logar convenientemente escolhido e envolvendo o outro em uma pasta de algodão para ser conduzido sempre na vertical, por um soldado a pé, de guarda-sol aberto. Fazendo variar a espessura da pasta de algodão consegui finalmente egualar as indicações dos dous thermometros em um mesmo dia e desta fórma obter em marcha, embora aproximadamente, a temperatura maxima e minima á sombra.

- A direcção dos ventos era tomada por processos rudimentares e a sua velocidade calculada por aproximação, á falta dos instrumentos apropriados. Os phenomenos relativos á vestimenta do céo apenas foram assignalados com referencia aos 
ly pos rapitales de muvens: cumulos, cirros, estratos c nimbos. listas quatro fórmas simples ou primarias foram seguidamente representadas, predominando, porém, a ultima, como era natural, visto que a expedição atravessou () sertão em pleno regimen das (huvas.

As indicações do pluviometro foram tomadas incompleta e unicamente quando a comitiva estacionava, pela impossibilidade de se agir de outra maneira.

Tivemos chuva em 57 dias dos 78 em que foi feita a nossa travessia; em io daquelles houve verdadeiros temporaes acompanhados de trovões, relampagos e descargas electricas para o solo.

Em relação aos hydro-meteoros devo assignalar que nunca foram observados nem a neve, nem a geada, mas constatou-se a existencia abundante do sereno ou cacimbo, como a dos nevoeiros - a cerração e a neblina — os ultimos, principalmente, depois que descambámos para os valles dos rios Commemoração de Floriano e Gy-Paraná.

- Dos meteoros electricos nunca foram observados os fogos de Sant'Elmo.

- Dentre os luminosos apresentaram-se varias vezes os arco-iris, não sendo observados vez alguma os halos, os circulos parhelicos nem as coroas.

- A temperatura maxima centrigada á sombra foi de 34 gráos e essa mesma uma unica vez; a minima foi de 16 gráos pela madrugada. 


\section{CAPITULO V}

\section{Serviços de geologia e zoologia}

Os serviços de geologia estiveram sempre sob a immediata responsabilidade do respectivo especialista, Dr. Euzebio Paulo de Oliveira de cujos trabalhos vos será apresentado o relatorio correspondente. Competindo-me facilitar os meios para que elles se executassem de conformidade com as necessidades expostas pelo geologo no correr do serviço tenho a certeza de que agi sempre nessa conformidade.

Os de zoologia limitaram-se aos do taxidermita Henrique Reinisch, que ao encerrar os seus trabalhos fez entrega de 59 tubos, com varios insectos e outros animaes; de 293 exemplares de mammiferos. aves e peixes, abaixo especificados conforme um rapido exame feito em todo material pelo zoologo Alipio de Miranda Ribeiro:

I6 mammiferos, dentre os quaes destacam-se, como documento biologico, um craneo de feto de Tapirus terrestris e um craneo de Mazama rufa, de chifre duplo. Dentre uma bôa collecção de pelles sobresahe a de um individuo adulto de cuxio de nariz branco (Chiropotes Albinosa).

I 87 aves, dentre as quaes bellissima cotinga (Ampellis purpurea) diversos periquitos raros (Conurideos); uma maitaca tambem rara (Pionus); dous exemplares de arara azul (arahyacinthina); diversas especies de Buconideos e Galbulideos raros; e uma bôa série de Formicariadeos. 
100 cixemplares de peixes pertencentes aos wrupes dos Scleracanthas e Chichlideos.

- Nus tubos havia 8 cobras, varios insectos dentre os quaes multiplos coleopteros, alguns bellissimos e raros.

Finalmente, perdeu-se na descida do GyP’araná um caixote contendo 400 borboletas. algumas raras e de côres brilhantes, e que tinham sido apanhadas em todas as zonas percorridas pela expedição.

Todo esse material foi por mim entregue nesta Capital ao zoologo Miranda Ribeiro, para ser classificado, conforme vossas ordens, afim de ser doado ao Museu Nacional.

\section{CAPI'TULO Y'I}

\section{Do contingente}

A maneira completa pela qual se desobrigou o contingente dos deveres que lhe foram impostos, assim como a fórma correcta e disciplinada com que se apresentou sempre aos olhos dos estrangeiros nossos hospedes. tudo reputo uma consequencia immediata da magnifica tempera do nosso caboclo e das boas qualidades moraes, intellectuaes e de commando, que caracterizavam a individualidade do commandante - o Tenente Joaquim Manoel Vieira de Mello Filho, além de tudo, um conhecedor desse mesmo sertão em que agiamos e onde trabalhara muito tempo na construcção da linha telegraphica, em epoca das maiores difficuldades. 
Entretanto cumpre assignalar que illudem-se constantemente os observadores superficiaes quanto ás qualidades praticas do nosso pessoal de trabalho. Podemos affirmar orgulhosamente que o nosso caboclo brasileiro é inexcedivel quanto devotado em trabalhos dessa natureza; afrontando todos os perigos do sertão com uma coragem stoica; mantendo espirito jovial, quando mesmo reduzidos á mais parca alimentação, como privados das commodidades mais essenciaes da vestimenta; resistindo com resignação a todas as intemperies; conformando-se facilmente com as mais penosas situações desde que se ponha em jogo, com certa habilidade, o seu exagerado amor-proprio; finalmente, conservando sempre o espirito docil, tão proprio do seu temperamento affectivo.

Tenho muitas vezes testemunhado que esse stoicismo não provem da inconsciencia do perigo ; em certa cachoeira de jusante dous homens descem em canôa, julgando que a travessia ahi é mais arriscada do que na outra de montante, onde acabava de morrer um companheiro, escapando difficilmente a nado o que agora de novo se promptifica a reproduzir esse verdadeiro desafio á morte!

- Naufragos do meu primeiro levantamento do rio Commemoração, salvos por accaso aguentando-se aos ramos da vegetação marginal, embora sem saber nadar, prevenidos de que ha um trecho mais perigoso a levantar, pedem-me que os conserve na turma porque " não teem medo de morrer ") !

- Ao fim dos trabalhos diarios, depois da marcha fatigante de quem carrega o que é seu, á chuva ou ao sol ardente, quasi todos os soldados e 
Givis trabalhadores, varias vezes pedem licença para dansar, executando saltos e voltas extenuantes, durante horas, até que o toque de silencio vem pôr termo a essa expontanea sobrecarga á resistencia muscular, durante cuja execução succedem-se as risadas e os ditos chistosos, só adaptaveis a quem se sente conscientemente feliz e despreoccupado...

Alguns que perdem os chapéos lamentam mais o prejuizo material do que a privação em que ficou de furtar a cabeça aos raios solares ou defendel-a das chuvas continuadas.

- Em varias occasiões em que, por circumstancias alheias á vontade dos chefes, torna-se a alimentação reduzida ao palmito e á caça problematica caso de que conheceis innumeros exemplos - continuam os homens a obedecer e trabalhar nas mesmas condições em que o faziam quando se dispunha de todos os recursos.

- Emfim multiplicam-se os exemplos que nos convencem da legitimidade da nossa apreciação pessoal em relação ao typo genuinamente nacional do caboclo - e seria longo citar maior numero delles, como esmiuçar detalhes que tornariam mais longa e mais fastidiosa esta exposição.

As marchas foram todas feitas a pé e á vontade, carregando cada homem o seu "sacco de mala" (sacco de aniagem ou de algodão forte, dentro do qual conduzem todos os seus trens, que mesmo assim, algumas praças conduziam com peso superior a 40 kilogrammas). - Dessa maneira commoda á vontade - de effectuar as marchas, sem a delimitação do tempo e outras exigencias regulamentares, desde que não iamos á guerra, resultava, porém 
a necessidade de estabelecer uma " escolta da retaguarda "s, já referida accidentalmente em outra parte deste relatorio e cujas vantagens não é preciso encarecer.

- Em começo da marcha por terra, as obrigações eram menores, pois que, reduziam-se a marchar c acampar diariamente, constituindo o maior sacrificio o transporte das cargas que os nossos muares iam deixando quando afroixavam. Posteriormente, a partir de Juruena, como já foi dito, acresceu a estas a reconstrucção das pontes e estivados do caminho, produzindo-se tambem, em consequencia da propia natureza do nosso serviço, a impontualidade das refeições, visto que a turma de concertos da estrada recolhia-se ao acampamento a horas variaveis, em funcção das difficuldades encontradas nestes trabalhos. Isto sobrecarregava ainda o pessoal empregado na cozinha dos acampamentos.

- O rancho " era distribuido militarmente, ào toque correspondente, fazendo-se sempre em primeiro logar a distribuição ás praças, finda a qual o corneteiro recebia então ordem de tocar " rancho para officiaes ", servido sempre sob a barraca do chefe da turma. Em relação á qualidade e quantidade de alimento, julguei interessante estabelecer no supplemento $n$. to o confronto das tabellas constantes dos supplemontos $n s$. $t I$, t2 e t3, muito elucidativos para apreciar convenientemente o regimen habitual de alimentação adoptado nesse sertão.

A cozinha de cada uma das tropas de bois e a da tropa de muares fazia-se isoladamente, em obediencia á praxe altamente conveniente de tornal-a 
independente da dos officiaes e praças, necessidade yue a pratica tem sempre demonstrado. A entrega de generos ao pessoal tropeiro, exceptuada a carne fresca, foi feita de uma só vez no inicio da marcha, computando-se pelo maximo o tempo da travessia projectada, calculando-se a quantidade pela tabella b' do annexo n. 39 e computando-se em 40 dias a duração da viagem.

A distribuição de generos ao contigente era, porém, diaria, havendo para esse fim um sargentointendente, incumbido tambem de fiscalizar a utilização desses generos e a maneira de preparal-os na cozinha. Produzia-se, em consequencia, uma economia que augmentava na razão directa do numero de arranchados, como é corrente. Tanto assim que, dispondo a minha turma em Campos Novos, no dia I3 de Fevereiro das seguintes quantidades de generos:

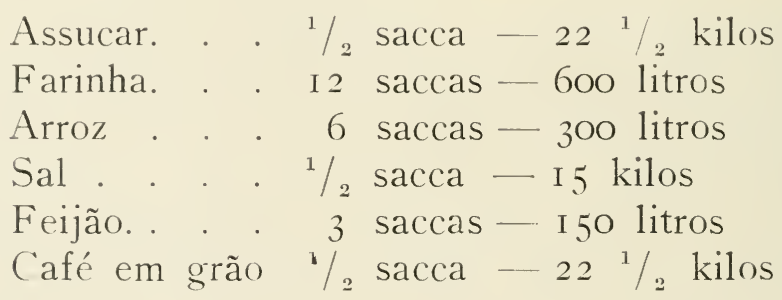

com estes alimentei todo o meu pessoal até 4 de Março, com algumas sobras; isto é, foram alimentadas 750 pessoas nesses i 9 dias, sendo noventa do estado-maior e 660 inferior e praças. Essas sobras, parte perdida no meu I. naufragio e parte cedida ás tropas que regressaram de Barão de Melgaço, constaram do seguinte: 


\section{3}

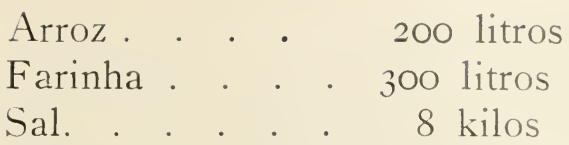

Fazendo o calculo das rações chegariamos aos seguintes quantitativos:

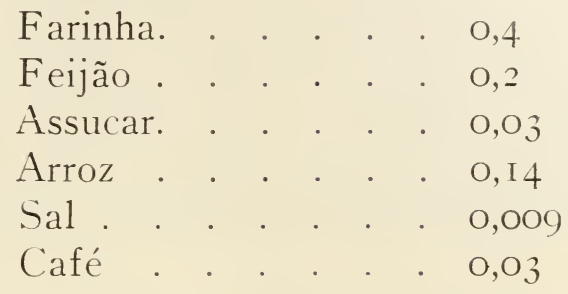

evidentemente inferiores á tabella $C$ que adoptaramos para a Expedição como se vê do supplemento 12. 70 .

- Ao almoço formava em duas fileiras todo pessoal e á proporção que cada homem sahia de forma para receber na barraca da cozinha a sua ração, recebia tambem das mãos de um dos empregados no rancho um caneco de agua fria e a capsula de 50 centigrammas de quinino inglês, que era ingerida ali mesmo. Ao rigor com que fiscalizavamos esta pratica prophylactica, atribuo a ausencia dos casos de paludismo durante toda a travessia até Manáos, quanto ao contigente. Em contraposição, o pessoal tropeiro, que recebia o quinino para tomar fora das nossas vistas, apresentou varios casos dessa molestia, que sempre consegui combater com doses elevadas de uma a duas grammas de quinino diariamente. Depois que cheguei a Manáos e apesar de multıplas recommendações para que proseguissem no uso do quinino durante mais 30 dias, distribuindo para isso 
1 mumero de ("ap)-ulas necessario, a falta dessa liscallisacãu directa fe\%-se logo sentir, pois que, todu o pesscoal. já então distribuido pelos corpos da guarnição, foi acommettido de paludismo, baixand: alouns ac) hospital.

Para attender ás necessidades da lavaegem de roupa que cada praça fazia para si, aproveitava-se (pualquer intervallo de tempo em dia de sol, sem prejuizo do trabalho, o que sempre foi possivel fazer, permittindo-se para isso a troca de serviço entre o pessoal escalado para cada turma.

\section{CAPITILO VIT}

\section{Das tropas e dos tropeiros}

Haveis de consentir que, aproveitando o ensejo de relatar-vos os successos e providencias que se prendem no meu serviço a este assumpto, divague $11 \mathrm{~m}$ pouco para tratar do problema capital para qualquer emprehendimento através do nosso sertão.

-E' uma das cousas que surprehende o homem da cidade, a maneira pela qual se resolve este complicado problema do transporte no sertão de MattoGrosso, causando maior admiração ainda a utilização do boi como cargueiro. O insucesso de varias expedições provém da má organização desse serviço, comparavel ao das grandes travessias dos desertos africanos, onde o camello representa tão importante papel. Trataremos em primeiro logar de muares.

Em regra o pessoal que se dedica a essa ordem de actividade é composto de goyanos e mattogrossenses e ha um chefe - o arrieiro - que supe- 
rintende todo o serviço, tomando a responsabilidade no maximo de 6 lotes (cada lote com io cargueiros). Quando é possivel os lotes dispõem de dous tocadores montados, sendo porém indispensavel um homem para cada lote. A conveniencia de haver dous, provém da necessidade muitas vezes de concertar a carga aos animaes, quando as circumstancias obrigam o descarregamento durante a viagem, o que exige que cada um dos tocadores se incumba de retirar a carga de um dos costados para recarregar depois, levando simultaneamente as duas cargas aos flancos do cargueiro. A alma da tropa é o arrieiro, que deve conhecer o " métier " e possuir bôas qualidades de mando e energia; tanto mais dedicação terá pelo seu trabalho quanto mais tempo lidar com a mesma tropa composta dos mesmos animaes, aos quaes dispensando mais carinhoso trato augmentalhes a capacidade de trabalho, conservando-lhes a resistencia physica. Os tocadores farão systema com um arrieiro nessas condições, exigindo-se-lhes porém no mais alto gráo a qualidade de bons campeadores. Os mais perfeitos dentre estes são capazes de acompanhar o rasto de um animal através da floresta, quasi como um cão que fareja a caça.

Ainda quanto á organização do pesoal, toda tropa dispõe de um cozinheiro, que acompanha sempre o I. ${ }^{\circ}$ lote.

- Quanto ao modo de executar o serviço, ha detalhes que passam despercebidos á primeira vista e que constituem ensinamentos da pratica, abrangendo os cuidados dispensados aos animaes e ao arreamento, palavras convencionaes com que os tropeiros se fazem comprehender pelos animaes, 


\section{6}

mancira de (arregar, uso das alças de couro ou das broacas. cte. Procurarei resumidamente passar em revista cada um destes pontos.

- Entre os cuidados que requer o tratamento dos animaes estão a precaução de leval-os á "aguada " (rio ou lagôa a que o animal póde attinwir para beber): a escolha do "encostos, onde (xista o melhor pasto e a configuração topographica difficulte a dispersão da tropa; a distribuição do milho em bornaes; uso diario de escova e raspadeira; precauções com o casco e ferraduras; conservaça do lombo dos animaes sempre em estado de receber a cangalha; tratamento de molestias; maneira de executar as marchas.

Chegada a tropa ao pouso á tarde, descarregados os volumes e retiradas as cangalhas, soltam-se os animaes para espojarem-se, sendo em seguida levados para a aguada, onde o arrieiro exerce grande fiscalização para evitar que fique sem beber qualquer dos animaes. Vão em seguida ao campo para pastar e ahi passam a noite. O "encosto " ideal é o que, possuindo bom pasto, difficulta a sahida dos animaes e o seu regresso pelo mesmo caminho por onde vieram; geralmente essas duas vantagens estão reunidas nas queimadas onde cresce a brotação nova do capim e em uma "resaca ", isto é, especie de hahia cercada de mata alta e impossivel de ser atravessada pelos animaes. com uma garganta de entrada. A tendencia dos animaes é voltar pelo mesmo caminho; de modo que, quando se tem atravessado um curso d'agua que não dá vau, consegue-se evitar a fuga dos animaes trancando a ponte com galhos de arvores entrelaçados. 


\section{7}

O milho é um alimento indispensavel para conservar a resistencia da tropa ; além disto a distribuição pela manhã, em bornaes, conforme os usos locaes, tem a vantagem de habituar os muares a procurar o acampamento, reduzindo assim o trabalho do campeio.

- Infelizmente houve necessidade de rejeitar o unico milho que existia em Tapirapoan quando dahi partiram as tropas da Expedição, o que motivou a perda de muitos muares. Convem dizer de passagem que o milho foi recusado por não estar secco e ter sido colhido ainda um pouco tenro, por conseguinte, em estado de não poder absolutamente servir para alimentação dos muares, como é sabido.

- Em rigor dever-se-ia distribuir duas rações de milho uma pela manhã outra á tarde, de 2 a 2,5 litros cada uma; mas, adoptamos de costume nessa zona de verdadeiro deserto, a condução de quantitativo necessario para uma ração que regula de I a I,, 5 litros, o que em uma travessia de 40 dias como a que fizemos, obrigaria a utilizar de 4 a 6 cargueiros em cada lote de io animaes só para conducção dessa forragem, se a Commissão de Linhas Telegraphicas não houvesse tido a previdencia de mandar fazer grandes plantações deste e outros cereaes, estabelecendo dous grandes pontos de apoio que são assim como verdadeiros oasis para as tropas que atravessam esse arido sertão - a invernada de Campos Novos e a Fazenda dos Tres Buritys, sitios onde além disso as pastagens são excellentes, em contraposição com o pessimo capim dos chapadões.

- Para conservar a resistencia da tropa e mantel-a em condições de marchar diariamente é indis- 


\section{8}

pensavel cuidar meticulosamente do lombo dos animaes, já evitando a troca das cangalhas de uns para outros cargueiros, já corrigindo os enchimentos, já distribuindo equilibradamente o peso dos costados ou collocando a cangalha em bôa posição relativamente á espinha dorsal, já finalmente accudindo aos estragos que o attricto das cangalhas produz sobre o couro do animal, provocando o apparecimento de ferimentos.

Concorre para essa conservação tambem a limpeza dos animaes com escova e raspadeira, evitando que se interponham corpos extranhos entre os suadores e o lombo, ou que o pello fique engrovinhado; embora essa limpeza tenha tambem o objectivo, aliás o principal, de satisfazer ao lado hygienico.

- Para referir-me logo aos outros pontos principaes relativos aos cuidados hygienicos, assignalo aqui um costume que me não parece logico mas contra cuja praxe não quiz antepor-me, receioso de que produzisse mau resultado a sua suspensão: quero falar na obrigatoriedade do banho aos cavallos, ao mesmo tempo que se veda o seu uso aos muares! Por que? - Dizem os praticos que o banho enfraquece (sic) os muares e robustece os cavallos; seria curioso fazer uma verificação systematica, pesquizando a causa dessa diversidade de consequencias.

O tratamento das molestias quasi que se reduz ao das feridas que se abrem ou que se arruinam, ás colicas communs e ás que provêm da ingestão de hervas, muitas vezes existentes de mistura com o capim de pasto e que envenenam. As primeiras encontram excellentes remedios na banha derretida e na creolina, esta como desinfectante; as segundas curam-se 


\section{9}

obrigando o animal a correr, no caso commum até transpirar fortemente ou fazendo-o ingerir, no outro caso, dóses convenientes de oleo de ricino ( 3 ou 4 garrafinhas de uma só vez). E' digna de menção a maneira pela qual se obriga o animal a ingerir o oleo, por meio do " cachimbo ", isto é, torcendo a pelle do beiço superior do animal dentro de uma pequena laçada de couro que se aperta girando um pequeno bastão. Chegando esta torção a certo ponto o animal " entrega-se " como dizem os tropeiros em sua giria, obedecendo com docilidade e denotando muitas vezes, por gemidos, a dôr que se lhes imprime por tal processo, tambem usado para marcar os anımaes com ferro em brasa. Nestes limites passa-se uma das extremidades de uma vara resistente por entre as orelhas do animal, apoiando-a fortemente sobre á crabeça ao passo que a outra extremidade prende-se acima do focinho a uma laçada collocada por dentro da bocca; a vara funcciona assim como uma alavanca do primeiro genero, forçando o animal a abrir a bocca, por onde se despeja então o liquido, quasi sempre deglutido com auxilio de massagens exteriores ao longo do canal respectivo.

- O exame dos cascos e das ferraduras são cousas tão corriqueiras que basta a citação para lhes comprehender o alcance, não valendo a pena esmiuçar tão conhecidos detalhes.

Quanto ao modo de executar as marchas, delle depende em grande parte a consecução do mais simples projecto de atravessar o sertão. Em primeiro logar vem a obrigação de ordenar pequenas marchas de 3,5 a 5 leguas ou 2 I a 30 kilometros por dia, evitando-se repetir este avançamento maximo em dias 
(nnsceutivos. Ém seguida vem a limitação do peso que cada muar pode transportar, cingindo-se aos limites de 2 a 3 arrobas ou 30 a 45 kilogrammas o peso para cada animal, sendo calculado em kilogrammas o peso do dôbro, cuja existencia resolve a conducção de pequenos volumes obrigatoriamente levados isoladamente, além de melhorar a amarra(ç̃o do " ligal " por meio da " sobre-carga ". Em terceiro logar, nesse sertão, para travessias mais ou menos longas, impõe-se desde começo a marcha a passo, não permittindo senão excepcionalmente o trote e considerando um crime o galope. Por mais extranheza que possa causar estas indicações, ellas são filhas da pratica, embora pareçam exageradas a quem quizer comparal-as com as médias observadas em identico serviço no interior dos Estados do Rio de Janeiro, Minas Geraes, São Paulo e Goyaz. Como os rio-grandenses do sul espantam-se e chegam a duvidar das marchas de 20 leguas tão naturalmente executadas pelo nosso cavallo creoulo do Norte, tambem os matto-grossenses do noroeste brasileiro mostram-se incredulos quando o goyano, o fluminense, o paulista ou o mineiro the referem suas viagens normaes de 6 a 7 leguas, a maior parte feita a trote, conduzindo cada cargueiro io a I 2 arrobas. - Os cuidados com o arreamento comprehendem : a raspagem diaria dos suadores da cangalha; o afofamento dos respectivos enchimentos; secagem ao sol da parte molhada pelo suor — quando isto for possivel ; sendo estas tres operações feitas pela manhã, antes de carregar a tropa.

- Para lidar com os animaes servem-se os tropeiros de uma giria toda especial por meio da qual 
conseguem fazer-se entender pelos muares, convencionando certas palavras que empregam tambeme com entonação especial para cada caso.

- A distribuição das cargas aos pares, o alceamento ou a utilização das broacas de couro, são feitos pelo arrieiro ou sob suas vistas immediatas. Para carregar começa-se por amarrar os animaes por meio de cabrestos a varas de grossura média, cortadas do mato, com altura de mais ou menos 2 metros, enterradas no solo. Em seguida collocam-se as cangalhas sobre os animaes e finalmente os tocadores dous a dous conduzem simultaneamente as cargas de cada par equilibrado pelo arrieiro, para as assentar ao mesmo tempo nos respectivos costados. O dôbro é escolhido e acommodado pelo arrieiro que é quem dá a ultima demão para fixar definitivamente a carga com os ligaes. Soltam-se os lotes isoladamente, isto é. cada qual com todos os animaes de que se compõe e cada lote só deve ser desamarrado da estaca depois de ter seguido o anterior alguns minutos para frente - geralmente o intervallo de tempo sufficiente para carregar um lote. A' frente do I. . lote que larga a " estaca ", sahe o cavallo madrinha da tropa, badalando o cincerro. Ha sempre um animal designado para guix da tropa e que leva um peitoral com guizos e campainhas (se a tropa tem apenas I ou 2 lotes) ou peitoral e cabeçada tambem com guizos e campainhas (se a tropa dispõe de 3 lotes para cima).

Monta por ultimo o arrieiro especie de inspector geral das tropas e dos tropeiros á cuja disposição fica um ajudante, quando a tropa tem mais de cinco lotes. As mercadorias que pódem soffrer algum pre- 
ju1/1, com o roçar dos galhos de arvores durante a marcha, o que é inevitavel mesmo nas melhores estradas do interior, são de preferencia mettidas nessas broacas de couro crú, onde tambem melhor ficam protegidas contra a chuva; as alças, tambem de couro crú, retorcido, são mais empregadas para o transporte de malas e caixões.

Em caminho procura-se manter unido o lote e conta-se de vez em quando o numero de animaes quando a attenção, por qualquer motivo, foi distrahida algum tempo e observa-se a posição das cargas e das cangalhas, acudindo aos desarranjos accidentaes e inevitaveis das cargas.

A's tropas de muares convem melhor viajar pela manhã e durante o dia pousando á tarde; em face porém das surpresas do campo, difficultando a sahida á hora matinal e por outro lado em vista da conveniencia de combinar as horas de partida, viagem e chegada, com as horas de refeição, alguns sertanistas nessa zona imaginaram resolver o problema com duas marchas uma pela manhã e outra á tarde - o que traz inconvenientes, entre os quaes o augmento de trabalho para o pessoal, além de se dever salientar que as horas de maior canicula, embora dedicadas assim ao repouso, não são utilizadas para pastar, conservando-se geralmente os animaes de pé, á sombra das arvores.

Um costume generalizado por toda parte em que se lida com tropa de muares é a designação de um animal para servir de madrinha da tropa ; habitualmente essas funcções são desempenhadas por $\imath$ m "cavallo-madrinha ", mas muitas vezes por um muar. A madrinha vae sempre em pello e sua func- 
ção mais notavel é a de congregar: em torrio os cutros animaes quando no campo.

Estes, assim habituados, concentram-se mais durante o tempo em que pastam, em redor $\mathrm{d}$ a madrinha, que por isso mesmo é constantemente perturbada pelo movimento que a tem por centro, ficando prejudicada dest'arte a sua alimentação.

- Logo á chegada a tropa recebe a indicação do local escolhido para seu pouso; na wirina turma esse local era tanto quanto possivel defronte á minha barraca. Fincam-se estacas para cada lote separadamente, mais ou menos sobre os pontos de uma ellipse, limitando interiormente uma area onde são arrumadas as cargas, apoiadas em dous paus roliços que se collocam paralellamente.

Exteriormente são amarrados os cargueiros que em seguida se descarregam para depois soltar, levando á aguada e ao campo de encosto. Por cima das cargas vão as cangalhas e para resguardar tudo da chuva, lançam-se por sobre as cangalhas os ligaes.

- O supplemento g evidencia que, partindo de Tapirapoan com 56 muares attingi o rio da Duvida apenas com I9, morrendo ou afrouxando pelo caminho 45 e desapparecendo 7 , tendo sido reforçada a tropa com i 5 muares recebidos durante a viagem; o que significa que só alcançaram o Duvida 4 animaes dos 56 sahidos de Tapirapoan.

A não ser logo em começo da travessia, em que tive necessidade de despedir um tocador, de uma feita, e ameaçar um outro de suspensão de vencimentos, como já vos communiquei em outra parte deste relatorio, o serviço foi feito da melhor fórma 


\section{4}

pelo pessoal de que dispunha a tropa, portando-se este muito bem e executando a pé a maior extensão do nosso percurso.

Todo esse pessoal sahira montado de Tapiraporan, mas foi apeando, á proporção das necessidades. afim de ceder os respectivos animaes para conducção da carça; antes de attingir metade do (aminho já estavam todos a pé.

- O Tenente Mello que aliás descançava muito seu animal para prolongar a resistencia delle, teve que marchar á infantaria quasi todo o trecho de Nicolau Bueno a Tres Buritys.

- Por força das mesmas circumstancias o taxidermista Reinisch houve que executar alguns kilometros a pé para chegar ao acampamento da cabeceira do Joaquim, e fazer do mesmo geito as duas marchas desse acampamento ao ribeirão Nicolau Bueno e dahi á fazenda dos Tres Buritys, onde requisitei outro animal para sua montada, conforme vossa autorização.

O addido Joaquim Horta, fez grande parte da travessia a pé, por ter afrouxado sua montada ao chegarmos em Gralhão, recebendo outro em Campos Novos e uma terceira em Tres Buritys e que o levou afinal ao termo da jornada.

\section{Tropa de bois}

Os methodos empregados para as tropas que utilizam bois como cargueiros, são semelhantes aos das tropas de muares. Ha entretanto differenças de detalhe que menciono como dados praticos, uteis para quem de todo desconhecer o assumpto. 
Quanto ás vantagens na escolha do animal, tem a primazia o bovino nessa zona do sertão, porque resiste melhor á falta de pasto, alimentando-se na mata com as folhas de palmeiras mal acceitas pelos muares e com folhas de arbustos que o muar repelle. Emquanto que raro é o muar que se adapta á necessidade de procurar alimento varando a floresta, o bovino pacientemente descobre o que comer na mata. O boi como cargueiro tem ainda a seu favor a possibilidade de dormir preso e a facilidade de viajar pela madrugada, o que além de tudo. prolonga a resistencia das tropas á fadiga. Neste particular é muito interessante o estudo comparativo dos supplementos ns. 8 e 9, com o intuito de estabelecer a percentagem de animaes que afrouxaram na marcha de Tapirapoan ao rio da Duvida, separando-os em dous grupos: muares e bovinos.

Felizmente se conclue dahi que essa percentagem foi de $65 \%$ para os primeiros e de $38 \%$ para os segundos, aproximadamente, mesmo considerando como frouxos os bois de minha tropa - deixados em Tres Buritys por se mostrarem bastante emmagrecidos - mas que poderiam, apesar disso, alcançar o rio da Duvida, se unicamente com elles devesse eu contar.

Além da resistencia o boi é ainda superior ao muar quando se transita por caminhos difficeis ou passando por dentro das florestas e onde é commum encontrar-se, por exemplo um grosso madeiro atravessado, sobre o solo ou acima delle mas a uma altura inferior á de um animal com cargas. O boi vence intelligentemente taes obstaculos, sendo admiravel a solução que dá para o segundo caso 
figurado. passando abaixado sob os paus, ao passo yue o muar em condições identicas, ou se detem, ou "refuga ", ou se tenta passar e sente pegar a carga, força violentamente para a frente, não raras vezes sahindo do outro lado em pello.

As cangalhas têm fórma differente, para melhor adaptar-se ao lombo, são menores, mais simples e mais leves, exigindo que, para sua conveniente accommodação, tenham tambem as cargas menor volume, embora conservando-se as médias de peso adoptadas para os muares.

- Em conformidade com os movimentos mais lentos, tão caracteristicos do gado bovino, varia tambem o modo pelo qual se dirigem aos bois os tropeiros, prolongando o syllabar das palavras convencionaes com que fazem-se comprehender, cantarolando muitas vezes em tom plangente.

Emquanto o tropeiro fala com energia, gritando rapidamente a sua giria para os muares, só se faz obedecer pelos bovinos falando lentamente, com entonação de quem quer amimar.

Taes observações como que se confudem com uma especie de psychologia applicada aos irracionaes, mas são colhidas nas lições da pratica e facilmente verificaveis pelos neophytos.

- O papel do cabresto no muar é representado aqui pelos lategos retorcidos passados pela base dos chifres do animal; todavia para os que não se encontram ainda perfeitamente mansos, usa-se atravessar uma argola ao focinho, onde se prende então uma das pontas da corda, cuja tensão obriga o animal a obedecer, dominando completamente qualquer indisciplina. 
Para estes casos usam muito os tropeiros atar á argola do focinho uma corda longa, geralmente um pedaço de couro trançado para laço gaucho, deixando-a de rastos afim de prevenir qualquer eventualidade durante as marchas.

- Taes são, a largos traços, as mais notaveis differenças de detalhe que eu desejava assignalar.

\section{CAPITULO VII}

\section{Ligeira noticia sobre os indios da zona percorrida}

Apesar de atravessar terrenos onde habitam indios Parecis, só vimos representantes dessa tribu dentre os que, já em contacto comnosco, serviram de tropeiros durante a expedição. Aliás uma grande parte desta tribu indigena está fazendo vida commum com os empregados da Commissão de Linhas Telegraphicas, onde os ha como tropeiros, guardas de linha e alguns mesmo praticando em telegraphia depois de se haverem instruido nas escolas primarias que funccionam sob a direcção dos telegraphistas encarregados das estações de Ponde de Pedra e Utiarity.

- Nhambiquaras e Pauatês, assim são chamadas as tribus de indios que encontrámos na nossa travessia: a primeira estende os seus dominios desde o valle do rio Papagaio até a estação telegraphica "José Bonifacio ", a ultima vive nas margens do rio Gy-Paraná ou Machado. Ambas subdividem-se em varios grupos com denominações differentes, 
ocupando vastas areas do nosso sertão. Nenhum indicio dão de serem antropophagos, apesar de muito suerreiros.

- Vivem inteiramente nús e alimentam-se de todas as fructas e de animaes, sem exceptuar mesmo dentre estes os gafanhotos e quasi todas as larvas.

- Quando já nos visitam com confiança como acontece aos Nhambiquaras das cercanias do Juruena, aprendem a dizer algumas palavras em português para pedir os objectos de que mais gostam como contas (missangas) machados, facões, fazendonos comprehender por mimica que apreciam esses artigos e os querem para seu uso.

- Especialmente os Nhambiquaras teem veneração pelos homens de barba longa; e este ornato causa-lhes tão bôa impressão que, á minima intimidade que se estabeleça, procuram elles roçar os seus rostos lisos de legitimo caboclo nas nossas barbäs, convencidos de que esta pratica lhes faculte a multiplicação e o desenvolvimento capillar.

- Ouvindo um nome proprio que lhes agrade, adoptam-no immediatamente e com elle baptiza-se logo um indio; mas se em seguida percebem um outro nome que lhes pareça mais emphatico, abandonam quasi sempre o primeiro, não sendo raro que o segundo seja tambem condemnado ao ostracismo como o anterior...

- Vivem alegres, riem facilmente e muito; algumas vezes percebi que criticavam costumes nossos com ar zombeteiro.

- E' um espectaculo inesquecivel a chegada desses indios aos nossos acampamentos, marchando um após outro numa interminavel fila, comple- 
tamente nús, carregando as mulheres os filhos pequenos e toda carga, emquanto que o homem só transporta o seu arco e flechas. Em visita de amizade, deixam estes petrechos bellicos escondidos no mato quando nos veem procurar.

- Possuem uma intelligencia clara e uma vivacidade notavel, applicando-as principalmente em estratagemas para suas caçadas ou contra seus inimigos nas guerras que manteem com outras nações indigenas.

- Para dar ideia da sua perspicacia refiro aqui a seguinte conversa entre um official da Commissão de Linhas Telegraphicas e um indio já em convivio comnosco: Pretendia o official demonstrar-lhe quanto era superior a carabina e a bala em confronto com o arco e as flechas que o indio usava. $\mathrm{O}$ indio ouviu todos os argumentos e propoz-se a demonstrar que as armas rudimentares de que se serviam eram superiores ás dos civilizados e pedio ao official que se sujeitasse apenas a uma condição: deixar sua arma 8 dias ao lado do arco e da flecha, dentro de um curso d'agua e ao 9. ${ }^{\circ}$ dia ambos irem ao local. retirar cada um sua arma e fazer immediatamente uso dellas.

A meu ver são muito mais intelligentes do que os caboclos do interior semi-civilizado do nosso Paiz, dos caboclos que cultivam roças de pequena lavoura, nas circumvisinhanças das aldeias e villas - especies de transição entre a civilização das cidades e a selvajaria do sertão bruto.

Como prova disto limito-me a citar o facto sempre constatado de comprehenderem os indios intuitivamente a significação dos mappas e o obje- 
(tivo de sua representação, mostrando que têm uma idéia nitida do conjuncto ao passo que sobre identico thema o outro (aboclo, no mesmo gráo de ignorancia do assumpto, apenas se mostra conhecedor do detalhe, restringindo este ainda ao estreito circulo dos acridentes que o cercam muito de perto.

Lembro-me, a proposito, de um facto que me referistes quando certa vez um indio, vendo um mappa em vossa barraca, indagou se não eram os "ios açuelles traços realmente representativos desse accidente topographico; como tambem vem a pello recordar o mappa rudimentar com que um outro indio vos explicava as posições relativas de diversos rios da mesma bacia hydrographica, figurando-os com traços sobre a areia.

- Segundo uma condemnavel mas expontanea tendencia, o nosso sertanejo semi-civilizado, logo que enceta relações de amizade com os indios, procura incutir-lhes os seus vicios, especialmente o vicio do fumo; este, para certas tribus é todavia o refinamento de habitos semelhantes já constituidos.

Entre os Nhambiquaras o fumo é recebido com muitas demonstrações de sympathia, mas é curioso que entregando-lhes o fumo picado e a palha prompta, sejam elles incapazes de enrolar um cigarro.

- De muito interesse como prova da confiança que lhes inspirámos já : um grupo de indios Nhambiquaras conservou a dezenas de metros do eixo da nossa linha telegraphica no ponto em que ella corta o rio "Festa da Bandeira ", o seu aldeiamento, na mesma posição em que existia antes de passar por 
ali a construcção. Desse grupo, no meu trajecto, encontrei ao longo da linha innumeros indios, a todos os quaes dirigia sempre a palavra a que respondiam com signaes de sympathia, repetindo com um sorriso tudo quanto eu lhes dizia : Bom dia. Como vai?" - Bom dia. Como vai? Aliás é isso muito commum entre todos os indios: imitar as nossas palavras e os nossos gestos, quando nos querem demonstrar o seu agrado e satisfação.

- De conformidade com os vossos processos humanitarios, tão bem recebidos pelo meu espirito quanto praticamente de resultados maravilhosos na catechese desses nossos irmãos e mais legitimos brasileiros, procurei sempre tratal-os com bondade $\mathrm{e}$ paciencia, offertando-lhes tudo quanto lhes podia ceder, mesmo objectos de meu uso particular, alguns dos quaes fazendo-me embora muita falta. E tenho a mais arraigada convicção de que sem quebrar essa norma, que se me afigura tão simples e natural, nenhuma violencia soffreriam os civilizados da parte dos indios, mesmo no caracter de invasores de suas propriedades, porque o homem-indio é tão affectuoso como o mais affectuoso dos civilizados. Destes até conheço innumeraveis casos em que pregam theorias e applicam praticas no sertão como se fossem elles os selvagens!...

Como bem sabeis houve mesmo quem pregasse a doutrina do exterminio dos nossos aborigenes e quem praticasse essa liquidação em grandes massas, nas celebres "batidas ", sob pretexto de que os indios atacavam os civilizados. De passagem convem fazer sentir que na grande maioria de $99 \%$ dos casos, o indio ataca em represalia: conta-se porém 


\section{2}

o ataque do indio mas não se conta o que se fez primciro com clle. Muitas vezes, como em muitissimos casos que vos são familiares, o civilizado isolado c armado de optima carabina encontra de supetão o indio armado de arco e flecha e, de medo, atira sobre clle; commettida a proeza, quande retorna aos companheiros em grupo, tem naturelmente vergonha de referir o facto como se passou e, invertendo a verdade, conta logo que defendeu-se de uma insolita aggressão, devendo o salvamento de sua vida á coragem com que enfrentou o perigo.

Ninguem externará por quê processos adquiriu um indio pequeno para seu serviço domestico, quando o extorquiu sob as mais tremendas ameaças nem sempre coroadas de exito, como no caso do individuo que insistia rudemente para levar o " corumim " (indio pequeno, creança, creio que segundo a "lingua geral " dos indigenas a que muito se referem os habitantes da Amazonia) e recebeu do indio uma contraproposta que ao mesmo tempo caracterizava a repulsa do pae aborigene e fazia sentir ao desalmado homem da cidade o que significava dar um filho.

- Desculpareis a digressão proposital para não perder um ensejo de vulgarizar injustiças e infamias de que são victimas os nossos caros indios, cujos sentimentos generosos bem merecem a apologia que lhes dedicou José de Alencar, o notavel escriptor patrio, em sua obra immoredoura e tão genuinamente nacional.

- Emquanto a minha turma viajava pelo rio Gy-Paraná aproveitámos nossa passagem para colleccionar objectos indigenas que só parte muito 


\section{3}

pequena conseguimos recolher ao Museu Nacional, quando regressámos ao Rio de Janeiro. Perderamos o restante desse material colhido ou foi elle furtado de bordo do pequeno paquete que nos transportou de Calama a Manáos.

O encontro fortuito com um grupo de Pauatês que, pelos esforços do Tenente Vieira de Mello e do Dr. Euzebio de Oliveira, conseguimos que confraternizasse comnosco, permittira-nos a acquisição de varios objectos de uso commum da tribu. Infelizmente, porém devido ao desapparecimento de um caixão ficou a nossa contribuição ao Museu reduzida a nove objectos que estão catalogados na secção competente daquelle estabelecimento e comprehende um enfeite de cabeça, um exemplar de ceramica, arco e flechas.

\section{CAPITULO IX}

\section{Ligeiras notas sobre a vida dos seringaes por onde passou a 2.a turma}

- Euclides da Cunha em phrases vibrantes e eruditas assignalou, através d'aquelle invejavel estylo tão original, a verdadeira situação dos seringueiros da Amazonia. Por toda parte vi confirmadas as suas palavras principalmente em relação ao modo pelo qual são cercadas ali as liberdades dessa pobre gente que trabalha na extracção da borracha, esğotando a largos haustos o seu copo de amarguras. Como um protesto pois e pelos beneficios que decorrem da citação desses abusos, peço-vos licença 
pira uma succinta exposição de factos, colhidos imparcialmente emquanto varava a zona dos seringaes em exploração.

A vida economica do seringueiro comporta interressantes observações relativamente aos desequilibrios de sua producção e do seu consumo.

Em epocas excepcionaes pode acontecer que a alta dos preços da borracha embolse-o de saldos (1ue se contem por algumas unidades de conto de

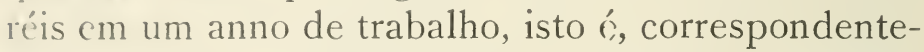
mente a seis mezes de effectiva actividade extractiva.

A normalidade porém é bem differente dessa illusão creadora de eldorados perpetuos. Basta recordar que um seringueiro póde produzir em uma safra 600 kilogrammas de borracha fina $o$ " sernamby ", utilizando-se para isso de cerca de 300 "madeiras" (seringueiras) existentes em duas " estradas" (picadas estreitas abertas na floresta para passar um homem a pé) ; o tirador de " cáucho » produz menos ainda.

Na occasião em que passei sendo a cotação da borracha na praça de Manáos inferior a 4 \$ooo por kilogramma da mais funa (denominada mesmo fina, ao passo que na escala descendente vêm depois a cutrefina e o sernamby de borracha) os productores recebiàm nos barracões o pagamento subordinado á seguinte tabella:

Por um kilog. de borracha fina defumada . $3 \$$ ooo

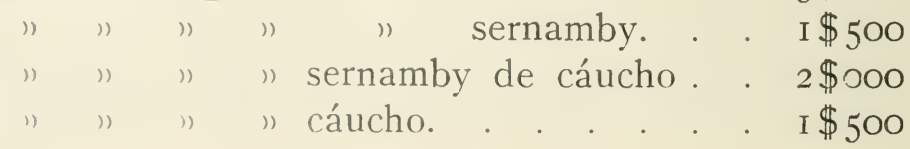




\section{5}

Concomitantemente adoptavam os mesmos barracões a seguinte lista de preços pelos quaes descontavam as despesas do seringueiro:

Por um kilog. de arroz, feijão ou assucar. 4 \$oco

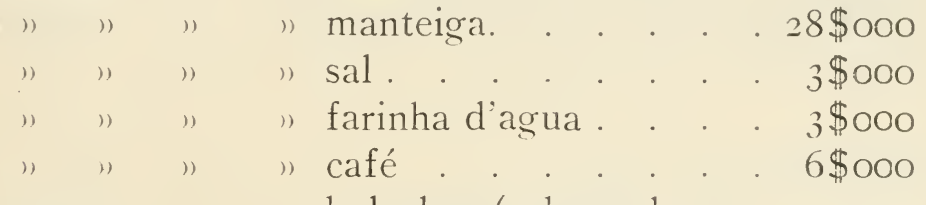

(aco) .

") bolachas (cabeça de ma-

Por uma lata de banha de 2 kilogrammas. $24 \$ 000$ " " " " leite condensado . . $8 \$ 000$ " um litro de kerozene . . . . . . $5 \$ 000$ ") " pacote de phosphoros. . . . 4 \$COO ") uma lata de sardinhas . . . . . . $6 \$ 000$

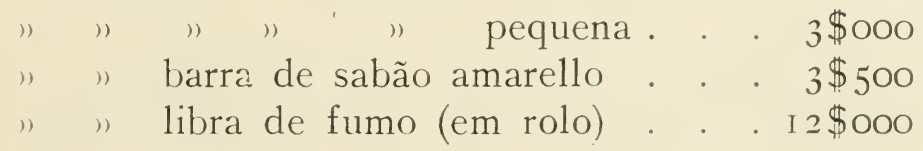

Carabina Winchester (rifle). . . . . 300\$oco Cento de balas para rifle . . . . . I00 $\$ 000$ Terçado com bainha. . . . . . . 35\$000 ") mais inferior sem cabo. . . $26 \$ 000$ Machado grande sem cabo . . . . 26\$000 " " para cortar seringa. . IO\$OCO Um prato de agatha com colher de chumbo $\quad 4 \$ 000$ Uma tijela de agatha com o, I 8 de diametro 4 \$oco Um lampeão de vidro protegido (pharol). $35 \$ 000$ Uma vela estearina. . . . . . . I $\$$ \$O00 Um cachimbo ordinario . . . . $7 \$ 000$ Um vidro de pillulas esanophelicas (carapanãs) . IO $\$ 000$ 
I'm vidro de pilulas de Bristol. . . $8 \$ 000$ " " " balsamo phil. . . . . I $2 \$ 000$ "1" " divino. . . . . . $20 \$ 000$ " " " clixir de Nogueira. . . $24 \$ 000$ I ma capsula de quinino ordinario . . I $\$$ ooo

Um terno de ganga azul . . . 30 \$0oo " " " riscado inferior. . . 40 4000 " par de chinellos. . . . . . . I $8 \$ 000$

" " " meias para homem . . . I0 $\$ 000$ " " " " " mulher . I $\$$. . $\$ 000$

" bonet ordinario . . . . . $15 \$ 000$

Facilmente se verifica a impossibilidade de conseguir que a renda sobrepuje a despesa emquanto a situação fôr essa, mesmo que o trabalhador attingindo ao maximo de producção, reduza ao minimo o consumo no barracão, auxiliando a sua manutenção com a caça e a pesca ou com os productos da pequena lavoura que plantar. Póde-se dizer em these que em taes condições de dispendio só é possivel o equilibrio quando o preço da borracha fina attinge a $6 \$ 000$ por kilogramma. Accrescente-se a tudo isto a possibilidade das molestias em zona onde excepcionalmente se encontra um homem sadio e tenha-se em mira que, recolhido por doente ao barracão, assume o seringueiro o compromisso de indemnizar o patrão de $4 \$ 000$ diarios pela comida que recebe, e ter-se-á mais um motivo de piedade para com esses brasileiros sacrificados por cruel 


\section{7}

sorte, a maior parte arrastada até ahi ou pela ambição propria ou sob a influencia de fallazes promessas.

- Nada porém valeria tão angustiosos compromissos se não fôra o regimen de feudalismo modernizado, tangenciando os dominios da escravidão do branco. Onde a liberdade tão amplamente garantida pela Constituição Brasileira?

A situação ahi é de tal natureza que dir-se-ia termos viajado por um paiz á parte, onde se fala a mesma lingua! Apartados do mundo, segregados da sociedade, explorados por todas as fórmas, entre as quaes abundam as mais requintadas modalidades da fraude, se,agindo de bôa fé ou sob os guantes da molestia que ameaça devorar-lhe a vida, quizer o seringueiro " baixar " (retirar-se aguas abaixo, por essas estradas liquidas que constituem as unicas vias de communicação) esse direito é-lhe vedado com a arrogancia e a insolencia de quem pune um criminoso.

A compressão é exercida de tal maneira que, ao desfilar com permissão de "baixar " a meia duzia de doentes, cujo estado de saude indica a proxima libertação das agruras mundanas, outros menos doentes ou sãos mesmo, exprimem desejos de attingir áquelle gráo de imprestabilidade, comtanto que se lhes permitta a faculdade de abandonar aquelles sitios!

- Revoltado com tão profunda anomalia, julgo necessario referil-a, por mais estreito que seja o circulo que me lê e por menos valioso que seja o meu testemunho pessoal, mais como um appello á vossa alma bem formada para que pugneis por uma 
aolucão que: vise libertar os nossos patricios de tão revoltante especulação, apontando o novo rumo que devat substituir a orientação actual, remodelando os processos, por outros que permittam o desenvolvimento da industria extractiva com a applicação de meins legaes e sobretudo humanitarios.

\section{CAPITULO $\mathrm{X}$}

\section{Conclusão}

Eis Sr. Coronel o que vos tinha a dizer relativamente aos trabalhos de que fui incumbido junto á expedição, assim como ás observações suggeridas durante a execução dos mesmos.

Tenho a consciencia de haver procurado cumprir com o meu dever, dedicando-me sinceramente e na altura das minhas forças para, com minima parcella embora, prestar o meu concurso ao extraordinario exito que obteve a expedição sob vossa chefia de facto.

Apresentando-vos pois o meu relatorio espero que de sua leitura guardeis a impressão do quanto procurei fielmente interpretar as vossas ordens e corresponder á confiança com que fui indicado para os cargos que exerci como ajudante e secretario.

Rin de Janeiro, 5 de Junho de I9!4. 


\section{SUPPLEMENTO N.I}

Kilometro Cincoenta, em 25 de Janeiro de 1914. Caro Chefe e amigo Sr. Coronel Rondon.

Ignoro se esta vos será por mim remettida de Aldeia Queimada, onde sei que até hoje está o Tenente Lauriodó, ou se a deixarei em Juruena. Sendo mais provavel esta segunda hypothese, desde já desobrigo-me do dever de elucidar-vos sobre a retirada dos companheiros que do salto da Felicidade não quizeram mais proseguir commigo-principalmente para salvaguardar a minha responsabilidade no pesado encargo que me confiastes.

Bati-me dogmaticamente contra semelhante resolução, julgando que seria sempre possivel com algum sacrificio, que na nossa situação não devia ser medido e pesado, levar a termo a incumbencia que nos foi distribuida ao organizar-se a 2.. turma da Expedição em Tapirapoan.

Os proprios companheiros podem attestar que desde o inicio da minha marcha declarei muitas vezes que tudo se deveria sacrificar menos o transporte do que fosse necessario á execução dos serviços que competiam a cada um de nós, caracterizando bem, especialmente em relação ao nosso 


\section{0}

companheiro Reis, que absolutamente não deveria pensar siquer em substituir "films" por conservas alimenticias e reveladores por doces e aveias, e que os animaes necessarios ao serviço de cada um eram sagrados. Neste sentido a primeira reducção feita attingiu logo os caixões de especialidades da confeitaria Colombo, com alguns protestos, embora muito humildemente tenha eu me conduzido como chefe, tcntando justificar a resolução tomada e procurando amenizar o primeiro golpe. Reduzida pois a nossa carga, a insistencias do Reis deixei-o organizar uns caixões especiaes onde elle reunia algumas parcellas retiradas dos caixões Colombo que sem protesto deixavam arrancar do seu seio alguns de seus mais dilectos filhos...

A' proporção, porém, que iam sendo fechados os "especiaes do Reis ", marcava-os eu com uma cruz fatidica que significava bem a minha intenção de relegal-os á cauda das nossas necessidades, recommendando ao Tenente Mello que não deixasse passar o " contrabando " senão depois de ter seguido a carga mais essencial.

Apesar de não ter animaes sufficientes mesmo para estas cargas que seriam a garantia da nossa marcha, não deixei carga aløuma em Tapirapoan, inclusive os caixotes "crucificados ", fazendo conduzir pela carroça o que havia restado depois de carregada a tropa onde inclui tres "voluntarios L. T. " que perambulavam pela cabeceira do Guanandy e pelo Barreirinho, um dos quaes era um burro preto que havia sido entregue pelo Lauriodó ou Mascarenhas ao João Hospicio afim de leval-o para a invernada, o que convem communicardes a 


\section{1}

esses dous companheiros afim de salvar a responsabilidade daquelle empregado. Relacionei tudo que ficou em Tapirapoan e deixei com o brigada copia da relação que fica em meu poder ; tudo deverá ser mandado para o Salto com auxilio das carroças, conforme ordenastes.

Com insistencia grande e arremedando tanto quanto possivel o vosso systema personalissimo, consegui partir no dia em que ordenastes, de Tapirapoan, mas a ultima tropa despachei pouco depois das 6 horas e 30 minutos pm. (! ?). Não preciso descrever-vos o que aconteceu nessa "memoravel " noite, bastando alguns detalhes para que a vossa experiencia permitta á imaginação reproduzir com exactidão todo o quadro. Um lote de burros attingiu o termo da marcha chegando tarde ao Salto e permanecendo na margem esquerda, outro espalhou-se completamente na sahida da mata; o I..$^{\circ}$ lote de bois attingiu mancamente Barreirinho onde chegou o $2 .^{\circ}$ á noite e parou ; finalmente, um lote de burros parou e acampou por minha ordem em pleno cerrado, com falta de dous burros e com outro burro sem cargas, nem cangalha, nem nada, de tudo o que despiu-se á custa de corcovos. Foi uma "debacle " comparavel á retirada de Mukdem, faltando apenas o bom general aqui.

$\mathrm{Na}$ madrugada do dia seguinte eu e o Tenente Mello, reunindo os destroços da batalha, marchámos sobre o Salto da Felicidade, onde acantonámos ás 5 horas pm. com tudo que havia ficado para trás, excepto 4 cargueiros com mantimentos que desappareceram e em cujo encalço deixei um campeador, sem esperança alguma de encontral-o porque o 
arriciru e mais dous tocadores já " bateram campo " atrís delles, em vão. Morreu tambem um boi suppõem que de mordedura de cobra e outro escapou-se atravessando o Sepotuba sendo aquelle cargueiro e. este adéstro.

Ao entrarmos, satisfeitos de ter cumprido o nosso dever, no rancho em que estavam os demais companheiros, ás 5 horas da tarde, nós sem almoçar nem jantar, encetei a discussão do problema da retirada dos companheiros e tive a franqueza de dizerlhes que era fóra de tempo a razão allegada quanto á separação das turmas porque esse protestu só seria opportuno em Tapirapoan; que seria de pessimo effeito moral semelhante regresso; que da pécha de fraqueza nenhum se livraria; que os serviços de botanica e zoologia não sendo dispensaveis e sendo muito justamente desejados por vós, poderiam entretanto, como os de cinematographia, deixar de existir sem comprometter o exito da travessia, mas que me competia protestar contra o procedimento do Dr. Soledade que assumira e acceitara a responsabilidade de prestar serviços clinicos á turma que agora abandonava na primeira marcha do sertão; que elle Soledade podia retirar-se " porque eu não tinha meios de impedil-o " mas que o fazia com o meu solemne protesto em face da responsabilidade que me atirava aos hombros, não em relação a mim e aos companheiros, que dispensavamos essa assis: tencia, porque podiamos fazel-o quanto ás nossas pessôas, mas nunca permittil-o quando se tratasse dos soldados! Declarando-nos a mim e ao Mello, o Dr. Soledade, que sentia muito deixar a turma assim, mais por nós, porque muito nos apreciava, 


\section{3}

respondi-lhe que se isso fosse a verdade elle seguiria comnosco. Apesar de tudo o Dr. Soledade terminou por dizer, emquanto os demais aguardavam vossa resposta, que de qualquer maneira voltaria, dali, quer fosse ou não dada a sua demissão.

Chamei tambem a attenção delles para o facto de que o desastre da retirada iria, além de magoarvos, reflectir-se na vossa pessoa que era afinal quem tinha organizado tudo, o que lhes dizia por ver que se faziam elogiosas referencias no abaixo assignado que vos enviaram, deixando transparecer até certa veneração.

Lembrei ainda que o desastre da primeira marcha não se reproduziria e que ao contrario da espectativa má que imaginavam, tudo melhoraria dali por diante, principalmente quanto aos animaes que não se conduziriam com a mesma indisciplina. Finalmente assegurei por todos os meios a possibilidade de chegarmos ao fim da jornada, accentuando que cada um sabia bem o que devia fazer e era responsavel por seus actos, mas que me competia a franqueza de dizer-lhes que não achava razão alguma nessa retirada. E imaginae agora se elles soubessem que para proseguir eu havia combinado com o Mello a reducção da tabella de generos (!) e que iria devolver minha bagagem toda, excepção apenas de um sacco de roupa; que o Mello iria fazer o mesmo, etc., etc.

Julgo assim que deante do que exponho aqui, far-me-eis a justiça de acreditar que procurei corresponder á vossa confiança e procurei agir de accordo com as vossas ordens, tendo a consciencia tranquilla se assim fôr, embora certo de que muita gente ha de 


\section{4}

suppôr que me deve caber a responsabilidade deste fracasso. - Peço apresentardes nossas saudações á I. "turma, especialmente ao Lyra.

Com grande consideração e estima, vosso amigo, camarada, subordinado e admirador. tmiliar llagalhães. 


\section{SUPPLEMENTO N. 2}

Salto da Felicidade, 23 de Janeiro de I9I4.

Coronel Candido Mariano da Silva Rondon.

Os membros da Commissão abaixo assignada por vós indicados para acompanhar a Expedição Scientifica Roosevelt-Rondon atravez do sertão do Estado de Matto-Grosso vem, com pesar vos communicar por meio desta exposição que não desejam proseguir nessa viagem por mais que ella lhes pareça honrosa e possa dar satisfação ao distincto chefe que a dirige pelos motivos que passam a expôr.

Sendo convidados na Capital Federal para acompanhar a mesma Expedição foram de accordo com a vossa ordem do dia n. 2 dispensados daquelle encargo constituindo uma $2 .^{a}$ expedição cujo fim seria, de accordo com a mesma ordem do dia a facilidade da locomoção por pequenos grupos. Apesar de terem deixado em Tapirapoan parte dos mantimentos e bagagens indispensaveis á subsistencia da mesma Commissão Brasileira em zona absolutamente sem recursos, nem assim lograram obter tropa capaz de transportar estas já reduzidas cargas ao primeiro pouso, deixando portanto transparecer logo no primeiro dia da marcha a impossibilidade de 
chesarem sem a espectativa de difficuldades insuperaveis, an ponto por vós indicado. Por isto, os membros da Commissão Brasileira, abaixo assiunada, considerando que para desempenharem as suas differentes especialidades precisam ser amparados de todos os indispensaveis recursos, quer de subsistencia, quer de locomoção; considerando que atravessam um dos sertões mais aridos do Brasil, ao mesmo tempo em que segue parallelamente uma commissão estrangeira melhor constituida de tropas e recursos; considerando por fim que, não ficaria bem ao Brasil qualquer desastre á Commissão, o qual traria interpretações desairosas á mesma, vem em conjuncto pedir as suas exonerações dos cargos que occupam, julgando assim que concorrerão para o desempenho dos serviços affectos aos companheiros que continuam na mesma Commissão Brasileira, esperando vossas providencias para que possam regressar e serem apresentados ás suas respectivas repartições no Rio de Janeiro. (assignados): Fernando Soledade, 2. Tenente; Luiz Thomaz Reis, Amaldo Blake de Sant'Anna e F. C. Hoehne. 


\section{SUPPLEMENTO N, 3}

\section{Relação do pessoal superior e alterações durante a marcha}

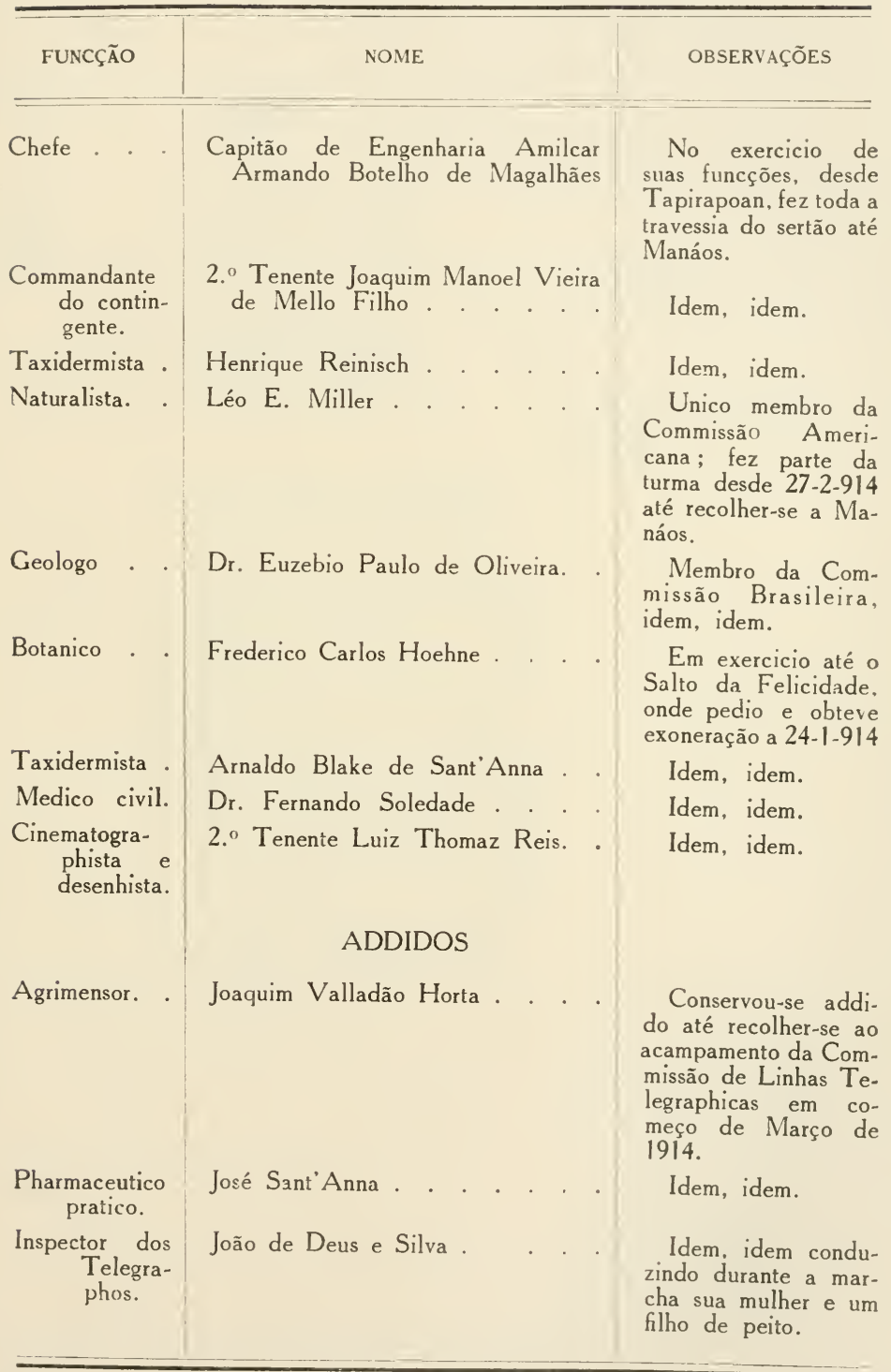





\section{Relação do pessoal de que se compunha o contingente da $2{ }^{a}$ turma}

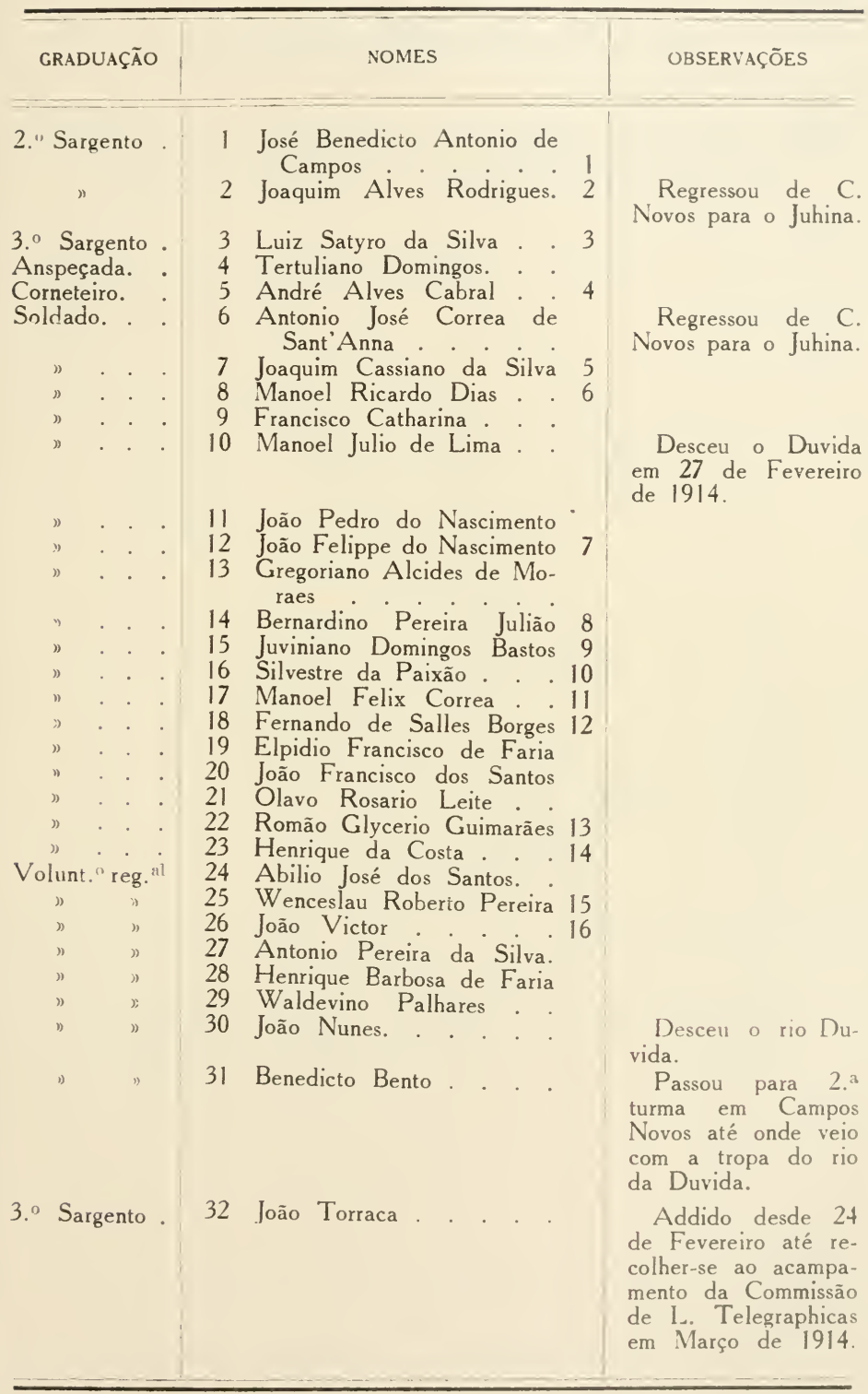

NotA. - A numeração á direita indica o effectivo ao partir de Tapirapoan. 



\section{SUPPLEMENTO N. 5}

\section{Relação do pessoal da tropa de bois que} acompanhou a 2." turma da Expedição

\begin{tabular}{|c|c|c|c|c|}
\hline $\begin{array}{l}\mathrm{N} . \\
\text { DE ORDEM }\end{array}$ & CRADUAÇC & $\tilde{O} E S$ & NOMES & OBSERVAÇÕES \\
\hline $\mathrm{I}$ & Arrieiro. & . & Pedro Augusto de Figueiredo. & (a) \\
\hline 2 & Ajudante & . & Joaquim Ernesto de Figueiredo. & (d) \\
\hline 3 & Tocador & . & Antonio Alves . . . . . . . . & (b) \\
\hline 4 &. & . & Pedro Cavalcante . . . . . & (a) \\
\hline 5 & ” & . & João da Cruz . . . . . . & (a) \\
\hline 6 & $n$ & . & Antonio Simplicio da Silva . & (d) \\
\hline 7 & $”$ & . & Jacintho Roque . . . . . & (a) \\
\hline 8 & ” & . & Fidelis José de Campos.. & (b) \\
\hline 9 & $n$ & . & Antonio Francisco de Oliveira. & (a) \\
\hline 10 & ” & . & José da Rocha Campista. & (a) \\
\hline 11 & $n$ & . & Sebastião Monge da Silva. . . & (a) \\
\hline
\end{tabular}
a) Regressaram de Barão de Melgaço para ficar em Campos Novos.
b) Regressaram de Barão de Melgaço para ficar em Tres Buritys.
d) Desceram o rio da Duvida. 



\section{SUPPLEMENTO N, 6}

\section{Relação do pessoal da tropa de muares que acompanhou a $2 .^{\text {a }}$ turma}

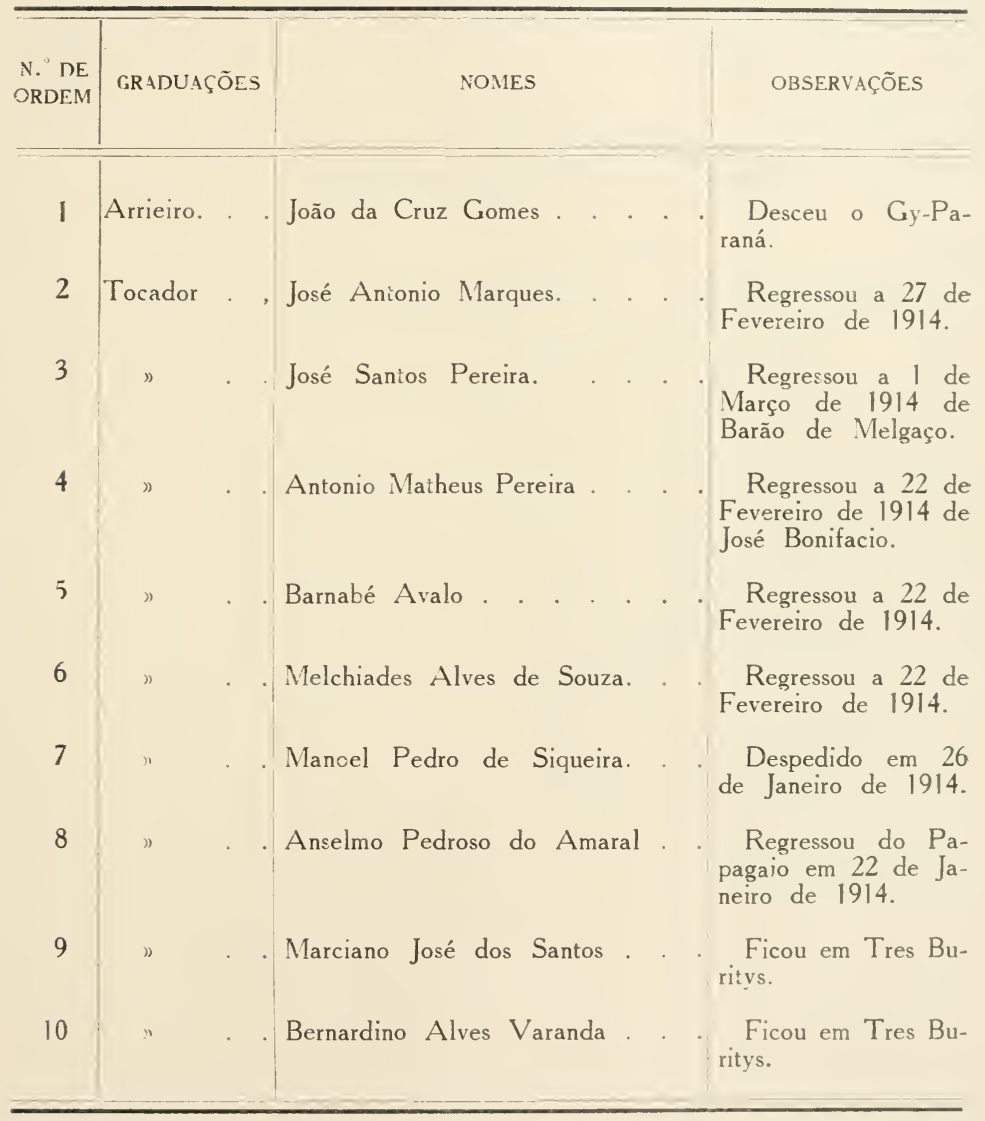





\section{SUPPLEMENTO N. 7}

\section{Relação do pessoal que acompanhou a tropa de bois do rio da Duvida}

\begin{tabular}{|c|c|c|c|c|c|}
\hline $\begin{array}{l}N .{ }^{\circ} \mathrm{DE} \\
\text { ORDEM! }\end{array}$ & CARGOS & & \multicolumn{2}{|c|}{ pnsto } & NOMES \\
\hline 1 & Arrieiro & . & Volun & reg. ${ }^{\text {al }}$ & José Izidoro da Silva. \\
\hline 2 & Ajudante & . & ” & ” & Luiz Correa. \\
\hline 3 & Vaqueiro & . & $"$ & $n$ & Francelino Honorato Avendana. \\
\hline 4 & $n$ & - & $"$ & 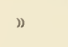 & Manoel Placido da Silva. \\
\hline 5 & ” & . & 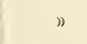 & " & Francisco Chena. \\
\hline 6 & $n$ & • & " & " & Albino Cavanha. \\
\hline 7 & $"$ & . & " & ” & Manoel Ribeiro do Nascimento. \\
\hline 8 & $"$ & . & $n$ & " & Antonio Vogado. \\
\hline 9 & $n$ & - & $n$ & $"$ & João Bernardo de Carvalho. \\
\hline 10 & $"$ & . & $n$ & $"$ & Carlos Palha. \\
\hline 11 & " & . & ” & n & Manoel Pedro do Nascimento. \\
\hline 12 & ) & . & » & $"$ & Benedicto Bento da Silva. \\
\hline
\end{tabular}





\title{
SUPPLEMENTO N. 8
}

\section{Expedição Scientifica Roosevelt=Rondon}

\author{
CARGA DE ANIMAES DA I. TURMA
}

Recebidos em Tapirapan:

28 muares de montaria.

7 cavallos de montaria.

$5+$ muares de cangalha.

Recebidos no Salto da Felicidade:

2 muares de cangalha.

Recebidos no Kilometro Cincoenta :

2 muares de cangalha.

Recebidos em Utiarity :

2 muares de cangalha.

Recebidos em Campos Novos:

2 muares de sella.

2 cavallos de sella.

Recebidos em Tres Buritys:

8 muares de cangalha.

I I 5 Somma.

DESCARG $\$$

I Sumido em Salto.

I Frouxo em rio Burity.

I Deixado em Utuarity.

I " " " Sacre. 


\section{8}

I Fromxo (m ribeirão Primavera.

Nhambiquaras.

Nedia 20 de Setembro.

2 Fromisos em (inariroloa.

2 " "Tendal.

2 " Macacos.

2 " "Formiga.

2 Perdidos em Primavera.

2 Frouxos em Morrinho do Lyra.

3 " "Utiarity.

3 " "Ikê.

3 " "Tres Buritys.

+ " "Grillos.

+ " " Buracão.

+ " " Mutum-Cavallo.

5 " Cachorro.

5 " " Sapezal.

5 " "Amarante.

5 " "Nicolau Bueno.

7 " "Campos Novos.

() " "Vilhena.

2 Deixados em 'Tres Buritys.

28 Regressaram do rio da Duvida. Cavallos :

2 Frouxos em Utiarity.

I Frouxo em Nhambiquaras.

I " " Vilhena.

3 Frouxos em Tres Buritys.

2 Regressaram do rio da Duvida.

I I 5 Somma. 


\title{
SUPPLEMENTO N,9
}

\section{Expedição Scientifica Roosevelt=Rondon}

\author{
CARGA DE ANIMAES DA 2. TURMA
}

54 bois cargueiros recebidos em Tapirapoan para conduzir carga do rio da Duvida.

23 bois cargueiros, idem, idem, para acompanhar a 2. ${ }^{\mathrm{a}}$ turma.

I 7 bois adestro, sendo 6 de corte, 6 de carro e 5 para cangalha, mas ainda chucros.

I cavallo madrinha.

56 muares cargueiros e de sella recebidos em Tapirapoan.

- muares da tropa do Tenente Coutinho recebidos em Campos Novos.

3 muares para montaria recebidos em Tres Buritys.

I muar encontrado na Barrinha.

I muar encontrado no Gralhão.

I 2 bois recebidos em Campos Novos, sendo $\delta$ da invernada e 4 da tropa do Coronel Rondon (I. ${ }^{a}$ turma).

Io bois cargueiros recebidos na fazenda de Tres Buritys.

3 muares comprados em viagem.

I 88 Somma. 
45 muares yue afrouxaram em viagem.

I cavallo madrinha idem.

- muares perdidos durante a viagem.

I 3 bois cargueiros deixados em Tres Buritys por imprestaveis.

I 2 bois de corte abatidos em viagem.

I boi cargueiro morto por mordedura de cobra.

3 bois cargueiros que afrouxaram em viagem.

2 bois cargueiros perdidos em Ribeirão das Aldeias.

I boi cargueiro morto por mim em Barão de Melgaço por estar pesteado.

I boi cargueiro deixado doente em Barão de Melgaço.

4 I bois cargueiros que voltaram de Barão de Melgaço com o Sr. Pedro Augusto de Figueiredo.

I9 muares que regressaram de Sete de Setembro e Barão de Melgaço.

22 bois, uns que repressaram com o José Izidoro de Sete de Setembro e outros que o inspector João de Deus abateu para alimentação do pessoal por estarem em más condições de fazer viagem.

20 bois deixados em Tres Buritys pelo Tosé Izidoro.

I88 Somma. 


\section{SUPPLEMENTO N. 10}

Aldeia Queimada, 24 de Janeiro de I9I 4. Hen caro Amilcar.

Salto da Felicidade.

Acabo de receber, com profundo pezar, um abaixo assignado, dos nossos companheiros da Expedição Dr. Soledade, Tenente Reis e botanico Hoehne com seus auxiliares.

Satisfazendo o pedido desses companheiros eu te peço de transmittir-lhes o meu assentimento, a que sou forçado pela má vontade com que elles se manifestam em nos auxiliar, fazendo excepção do botanico Hoehne, que mais de uma vez deu prova de coragem e de boa vontade de trabalhar.

A este fiz uma proposta no sentido de aproveitar os seus serviços no Papagaio e no rio do Sangue. Si elle não acceitar deverá seguir com os demais demissionarios para Caceres, correndo todas as despezas de volta por conta dos respectivos Ministerios a que pertencem, porque nada mais terão com o Ministerio do Exterior desde esta data 24.

Peço-te proseguires com o Tenente Mello trazendo a organização da tropa como estava.

A bagagem desses companheiros seguirá para Tapirapoan numa carroça e elles irão em outras por- 
que nà unos animases para elles irem montados alci lí.

Mande "sarento I zaac providenciar para que usas varroças venham, isto é, esse sargento desi- nará uma praça para levar o teu bilhete ao Brigada, mdenando a este enviar duas carroças para aquelles fins. Elles poderão, se quizerem, mandar vir de Tapirapoan, animaes para a sua montaria, caso lá encontrem.

Recommende-me ao nosso amigo e camarada Nello e receba um meu abraço e outro do Lyra, de agradecimento pela solidariedade que nos votou em tão triste emergencia. Com carinho e muita amizade amigo devotado - (assignado) Rondon.

P. S. - Peço accelerares a marcha deixando aqui tudo que não precisares. O automovel conduzirá essa carga para Uty.

(Assignado) Rd. 


\section{SUPPLEMENTO N. 11}

\section{Marcha do contingente que acompanhou a 2. ${ }^{\text {a }}$ turma}

\begin{tabular}{|c|c|c|c|c|c|c|c|c|}
\hline MEZES & DIAS & POUSOS & & & $\frac{c}{c}$ & 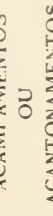 & 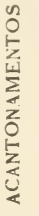 & 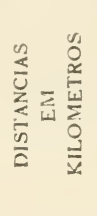 \\
\hline 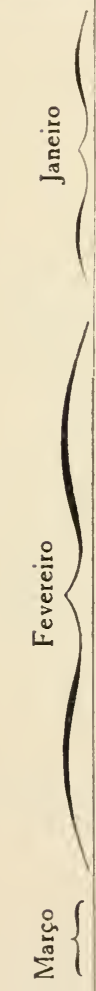 & $\begin{array}{r}22 \\
23 \\
24 \\
25 \\
26 \\
27 \\
28 \\
29 \\
30 \\
31 \\
\\
1 \\
2 \\
3 \\
4 \\
5 \\
7 \\
8 \\
9 \\
11 \\
12 \\
13 \\
16 \\
17 \\
18 \\
19 \\
20 \\
22 \\
22 \\
27 \\
28\end{array}$ & 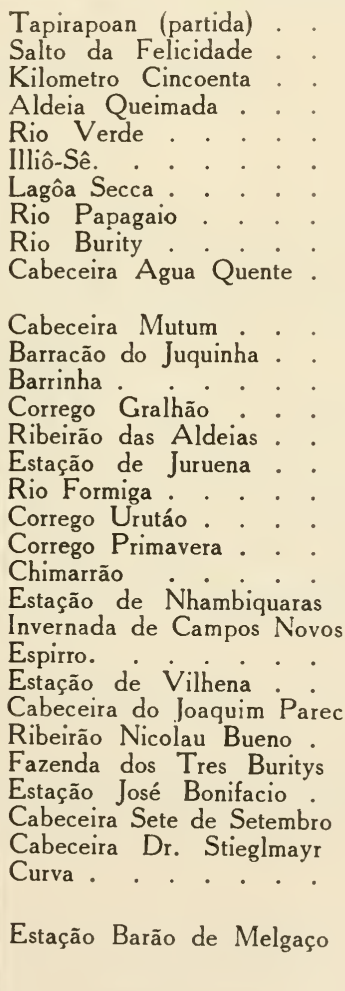 & $\begin{array}{l}\cdot \\
\cdot \\
\cdot \\
\cdot \\
\cdot \\
\cdot \\
\cdot \\
\cdot \\
\cdot \\
\cdot \\
\cdot \\
\cdot \\
\cdot \\
\cdot \\
. \\
\end{array}$ & . & 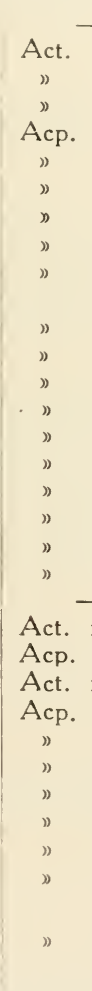 & 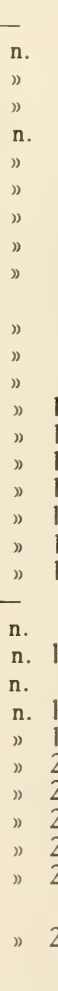 & $\begin{array}{r}4 \\
17 \\
5 \\
18 \\
19 \\
20 \\
21 \\
22 \\
23 \\
24\end{array}$ & 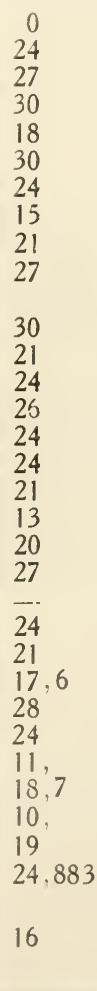 \\
\hline
\end{tabular}

Distancia total percorrida, entre os pontos extremos em trinta dias de marcha a pé $661^{\mathrm{km}}, 483^{\mathrm{m}}$. 



\title{
SUPPLEMENTO N. 12
}

\author{
Ariso urgente de Cuyabí 524 \\ 8 de Fevereiro de igr 4.
}

Capitão Amilcar.

Juruena.

Sciente i i 8 e i 20. De Juruena para José Bonifacio o peior trecho e que exige mais trabalho é de Amarante a José Bonifacio especialmente estivado Festa da Bandeira.

Estivados de Juruena a Nhambiquaras tambem devem precisar concerto como melhor te informará tenente Marino. De José Bonifacio a Barão de Melgaço tambem estivados máos, faço os mais ardentes votos pela tua saude e felicidade.

Abraços affectuosos.

(Assignado) Julio, chefe do districto da conservação. 


\section{Juruena, 6-Fevereiro de Igl4.}

\section{Tenente Julio Cartuno.}

\section{Lagôa Secca, 28 de Janeiro de igi4.}

Em marcha para Juruena de onde enviar-te-ei este, peço-te informares com urgencia quaes os pontos mais necessarios concertos estrada linha Juruena-José Bonifacio.

Estou incumbido destacamento Tenente Mello preparar estrada passará Coronel Roosevelt, mas levo tropa pessimas condições obrigado deixar generos atrás, preciso apressar minha marcha, por isso informarás o que indispensavel concertar.

(Assignado) - Amilcar. 


\section{SUPPLEMENTO N. 13}

Ariso de Barão de Melgaço 4

$$
7 \text { de Fevereiro de igi4. }
$$

Sr. Capitão Amilcar.

Juruena.

Ha dias vim de Nhambiquaras, dessa viagem observei o seguinte: Picada acha-se maior parte roçada havendo trechos sujos como seja de Guanandy ao Espirro, do Ribeirão Amarante ao Lyra, dos 3 Buritys a José Bonifacio, igualmente daqui ao Acampamento do Formigueiro tudo isso ainda muito sujo. Quanto ás pontes e estivados encontrei quasi todos em pessimo estado; acham-se diversas turminhas, apurando esses serviços entretanto creio se já não concluiram é devido á insufficiencia pessoal nas secções. São estas as minhas informações apezar não estar nas minhas attribuições esses serviços.

Rp. I 2 I /6 Saudações.

(Assignado) Adclino, encarregado da estação. 


\section{8}

$$
\text { Juruena, } 6 \text { de Fevereiro de } 1914 .
$$

Iv. n. $121-B$

Urgente.

Ençarregado da Estação de Barão de Melgaço.

Afim de cumprir ordens Sr. Coronel Rondon, preciso me informeis o estado em que se acha estrada da linha cujo trecho conservação compete estação vosso cargo visto que por ahi deverá transitar Sr. Coronel Rondon e sua comitiva acompanhado tropa mais ou menos cento e vinte cargueiros.

Saudações cordiaes.

(Assignado) Capitão Amilcar Magalhães. Ajudante Commissão. 


\section{SUPPLEMENTO N. 14}

Aviso de Nhambiquaras 23.

7 de Fevereiro de igi4.

Capitão Amilcar.

juruena.

Sciente vosso I 2 I. O trecho pertencente a esta estação está intransitavel devido o estivado do Camararé grande que está desfeito e diversos lugares que tem atoledos a picada muito estreita e com muitos tocos.

(Asignado) Encarregado Abreu. 


\section{Juruena, 6 de Fevereiro de igi4.}

Av. n. 121

Lrente.

Encarregado da Estação de Nhambiquaras.

Afim cumprir ordens Sr. Coronel Rondon, preciso que me informeis o estado em que se acha estrada da linha cujo trecho conservação compete estação vosso cargo, visto que por ahi deverá transitar Sr. Coronel Rondon e sua comitiva acompanhados tropas mais ou menos cento e vinte cargueiros.

Saudações.

(Assignado) Capitão Amilcar Magalhães. Ajudante Commissão. 


\title{
SUPPLEMENTO N. 15
}

\author{
Aviso de Tilhesa 25. \\ 7 de Fevereiro de igi4. \\ Capitão Amilcar. \\ Juruena.
}

Rp. I 2 I de hontem. Conservação estrada $4 .{ }^{2}$ Seccção está a cargo do encarregado da mesma Sr. Pedroso. Porém apresso-me a informar que no caminho para José Bonifacio, os estivados estão podres difficultando passagem de animaes, caminho para Campos Novos tambem existem algumas pontes cahidas, porém serão concertadas antes passagem comitiva.

(Assignado) Lima.

Telegraphista encarregado da estação. 


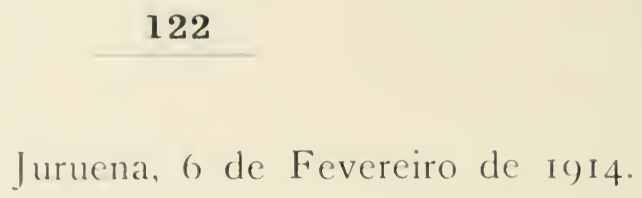

A1. 11. 121 A.

Uirgente.

Encarregado da Estação de Vilhena.

Afim cumprir ordens Sr. Coronel Rondon, preciso que me informeis o estado em que se acha estrada da linha cujo trecho conservação compete estação vosso (argo, visto que por ahi deverá transitar Sr. Coronel Rondon e sua comitiva acompanhados tropas mais ou menos cento e vinte (argueiros.

Saudações.

(Assignado) Capitão Amilcar Magalhães. Ajudante Commissão. 


\title{
SUPPLEMENTO N. 16
}

\author{
Juruena, 8 de Fevereiro de igi4.
}

Sr. Coronel Rondon.

Meus mais respeitosos cumprimentos assim como dos demais membros da 2. ${ }^{a}$ turma, todos os quaes pedimos apresentar nossos saudares illustres companheiros I. ${ }^{a}$ turma. Felizmente nosso grande susto chegar atrazados dissipou-se aqui. Seguimos hoje para o Formiga onde pretendo acampar. Conforme verificareis por minhas cartas anteriores minha situação melindrosa, tropa em máu estado, obrigou-me levar daqui uma carreta e utilizar meu serviço transposte 6 bois de carro do Lulica que seguem com os meus bois de corte por vossa ordem. Sei que recommendastes todo cuidado com esses bois e que elles não se destinavam ao serviço da Expedição mas além da situação que já conheceis até minha partida do Ribeirão das Aldeias, ainda fui obrigado a deixar lá mais cinco burros frouxos e dous bois perdidos com gente na "arribada ". Durante minha marcha afrouxaram, de Ribeirão para Juruena, mais dous burros cujas cargas aqui chegaram em costas. Para meu serviço requisitei e espero levar daqui tres machados e quatro facões pedidos ao Tenente Marino. 
l'erovos permissão lembrar-vos necessidade telecraphardes Rio sobre dispensa pessoal salto, afim serem dadas demissão Ministerio Exterior e feitas alteraçoes Malheiros, ao qual tambem me parece necessario remetter relação todo pessoal que passe a vencer pela folha Expedição, segundo li em aviso que Tenente Lauriodó mandou-me de Utiarity.

Apresento finalmente votos feliz exito vossa tarefa difficil.

Com muito respeito e admiração vosso subordinado amigo

Lmilcar 1. B. Magalhães. 


\section{SUPPLEMENTO N. 17}

Nhambiquaras, I 3 de Fevereiro de i9i4.

Carissimo Lyra.

De passagem por esta estação onde não acampo devido á falta de pasto para animaes, deixo-te aqui este bilhete com a preoccupação enorme da forma pela qual fui obrigado a " alinhavar " esse precipicio que se chama a ponte do rio Camararézinho. Para tranquillizar a minha consciencia peço-te telegraphar-me Vilhena dizendo-me se tudo passou bem ali pois que limitei-me a concertar o essencial mas receio que a parte que julgamos solida tenha feito alguma "franceza ". Em um osso de boi, por precaução, deixei escripto um aviso - em máo português e pessimo francês - para que passassem os animaes puxados, tal a pouca confiança que me inspira a parte que pareceu solida e a que, reconhecidamente compromettida, não era tarefa para o serviço da vanguarda que vou fazendo, obrigado a marchar conservando a frente, com os homens carregados de generos e malas com seus "trens"...

Junto ao Commandante a quem expliquei isto tambem na carta que aqui deixo, peço-te fazeres a defeza que nos cabe de justiça, porque bem avalias como teriamos encontrado tudo pelo caminho.

Desejando a tua saude e todas as felicidades que mereces envio-te os abraços do Mello, no mesmo monte em que te mando os meus.

Teu collega e admirador

Amilcar. 



\section{SUPPLEMENTO N. 18}

Nhambiquaras, I 3 de Fevereiro de igi4.

Av. n. I4 I

Coronel Rondon.

Nhambiquaras.

Participo-vos que requisitei e recebi no meu I 6. ${ }^{\circ}$ acampamento no corrego Chimarrão um boi de corte dos que conduzia a tropa do José Izidoro sob as vistas do inspector João de Deus. Proseguindo nas informações que vos hei prestado no correr de minha marcha, communico-vos ter ficado frouxa na estação de Juruena uma besta de montaria com a marca da Commissão L. T. tendo ficado no trajecto de Juruena ao Formiga o cavallo-madrinha da tropa, um burro pello de rato escuro, uma mula grande vermelha e uma pampa, todos os quaes nem em pello conseguiram vencer a distancia estre esses dous pontos.

Dos tres burros em cuja arribada deixei dous tocadores no corrego Gralhão apenas, foi encontrado um que veio juntar-se a nossa tropa ; os dous cargueiros que tinham fugido no ribeirão das Aldeias tambem não foram encontrados pelos campeadores que ali deixei para procural-os. 
Afromion un bon carcueiro que mandei soltar no corrego Rocedro, quando marchavamos de Riberiòo a Juruena.

Na minha marcha do Urutío ao Primavera afrouxou a besta do (hiquinho Mascarenhas que vinha já com cangalha dando serviço á Expedição desde Papagaio. Do Pimenta ao Chimarrão ficaram dous burros, um baio e outro branco, que mesmo em pello poucos metros andaram depois do I. corrego ; em seguida foram afrouxando mais quatro animaes (arqueiros, dos quaes um só poude chegar até o ( 'himarrão

Dos ig burros especiaes que o Sr. Juca nos vendeu, resta na minha tropa apenas $u m$, tendo afrouxado i 7 e perdendo-se um.

Todos os bois de carro que comprei para córte em Tapirapoan já estão sob cangalha, o que forçou-me a pedir um, para alimentação do meu pessoal, á tropa do João de Deus como já vos disse linhas atrás. Espero que seja possivel receber em Campos Novos alguns bois para o consumo de minha turma.

Como vêdes a nossa situação em relação a tropa é cada vez mais precaria, de modo que o nosso pessoal está sobrecarregado com as cargas que foi possivel distribuir-1hes como "dôbros " a accrescentar aos " costados" dos seus respectivos saccos de mala.

Estamos nos limites da estricção e antes que se rompa o equilibio espero que me mandeis soccorrer em Campos Novos.

Dos 40 burros cargueiros com que partimos de Tapirapoan, restam-nos i 5 (quinze). E' quasi uma 
reducção á expressão mais simples... Nas condições em que marcho, obrigado a fazer os homerıs carregar parte da nossa carga, com a necessidade combinada de conservar a vanguarda de uma turma em que vem o Coronel Rondon, espero que justificareis os remendos grosseiros que vou fazendo da estrada, por não ser possivel concertar melhor as pontes e estivados por onde deve transitar o Coronel Roosevelt e sua comitiva. Só se visseis o estado em que os encontro poderieis avaliar quanto nos temos esforçado para conseguir ao menos que fiquem transitaveis esses destroços de obras cuja construcção deveria ter consumido muita energia e muito trabalho.

Tenente Mello, Horta e Reinisch muito se vos recommendam como aos demais companheiros da I. $^{a}$ turma, o que tambem faz o vosso subordinado amigo e admirador

$$
\text { (Assignado) Amilcar Magalhães. }
$$





\title{
SUPPLEMENTO N. 19
}

\author{
Juruena, i I de Fevereiro de igi4.
}

Av. n. I 34-A.

\section{Capitão Amilcar.}

Chegámos aqui na occasião em que partias. Ficámos satisfeitos pela energia das tuas marchas que assignalarão uma nova era exploração do grande sertão.

Recebi tua carta e todos teus avisos me inteirando de tudo. Esclarecimentos sobre o procedimento desleal e antipatriotico dos retirantes telegraphei ao Ministro do Exterior pondo a par de tudo, mesmo para evitar-te desgostos.

O Coronel Roosevelt telegraphou ao ministro taxando de medrosos, desobedientes e insubordinados os retirantes.

Precisamos medir nossos recursos antes de chegarmos ao rio da Duvida. Convido-te para isso fazer um alto em Campos Novos lá nos esperar.

Affectuosas saudações.

(Assignado) Rondon. 



\section{SUPPLEMENTO N. 20}

Nhambiquaras, I 3 de Fevereiro de I9I4.

Av. n. 145 .

Coronel Rondon.

\section{Nhambiquaras.}

Tenho prazer de accusar vosso aviso n. 23 I de Io, transmittido de Juruena para esta estação por onde passei hoje afim de acampar em Campos Novos onde ha bom pasto para a nossa tropa. Darei vossas ordens ao arrieiro Joaquim Fagundes e procurarei verificar que as cumpra.

Unicamente o que me está preoccupando é esperar-vos quando é certo que, passado Nhambiquaras, teria eu dous dias de avanço sobre vossa turma pois tereis provavelmente de demorar ao menos um aqui em Nhambiquaras; e esses dous dias poderiam servir para eu ter tempo de concertar a ponte do "I 2 de Outubro " e, posteriormente a Vilhena, a do Festa da Bandeira - pontes muito estragadas, conforme informações do Tenente Julio e dos encarregados das estações, aos quaes pedi noticias estradas trechos conservação da linha sob 


\section{4}

sua responsabilidade. Saio daqui para Campos Noves reflectindo na possibilidade de combinar o cumprimento dessa vossa ordem rom o desejo de partir com toda pressa.

Se em todo caso outra providencia vos occorrer loger) yne aqui (hegardes, peco-vos mandal-a com ureencia, a ('ampos Novos, afim de poder eu seguir para a frente antes de vossa chegada ali.

Com us cumprimentos dos demais companhei ros de minha turma, pede-vos licença para abraçar vos com todo respeito e amizade vosso camarada, sulurdinado e amigo

(Assignado) .milcar A. B. Magalhães. 


\section{SUPPLEMENTO N. 21}

\section{José Bonifacio, 22 de Fevereiro de rgi4.}

Sr. Coronel Rondon.

José Bonifacio.

Tenente Jaguaribe a quem pedi interessar-se credito pedistes officio Caceres telegrapha-me solicitando-vos telegraphardes de José Bonifacio ao Sr. Ministro Exterior esse respeito afim poder tratar assumpto do conhecimento ministro. Aproveito ensejo lembrar-vos conveniencia prevenir hypothese rio Duvida cahir Tapajoz, solicitando Sr. Ministro providencias, semelhantes ás que suscitastes relação Amazonas, quanto governador Estado Pará.

Partecipo-vos que entreguei em Tres Buritys ao Sr. Miguel Lucas Evangelista i 3 burros frouxos da minha tropa sendo io a elle em pessôa na fazenda, um que ficou em Nicoláu Bueno e dous que deixei no primeiro corrego perto da fazenda, sendo um destes precisa ser tratado pisadura lombo, conforme communiquei; tomei ali 3 animaes de montaria um Tenente Mello, outro Horta, outro Reinisch; ficou com meu consentimento em Tres Buritys o vaqueiro Bernardino Varandas que declaroume ter vindo para ahi ficar com o Sr. Francisco Mascarenhas; deixo em José Bonifacio o tocador Antonio Matheus Pereira, a seu pedido, por não 


\section{6}

faze falta ao servico; pedi io bois carguciros em lore buritys porque li o aviso que passastes pedindo outron 10 c pondo os de mais á disposição do Tenente ('outinho: como Sr. Miguel não trouxe-os a tempo deivei P'edro Augusto recebel-os e fazer madrugada indo alcancar-me em 7 de Setembro.

( imprindo vossas ordens em aviso que hontem recebi c'm Tres Buritys fiz seguir João de Deus que hontem mesmo levantou acampamento continuando viagem para Pimenta Bueno; com elle seguiram 3 regionaes que se recolherão depois ao acampamento geral Calixto ou Carlos Palha, Antonio Vogado e João Benedicto de Carvalho; levou elle uma barraca que deve ser tambem entregue no acampamento geral e quatro bois cargueiros para conducção de suas cargas e alimentação; fiz tambem seguir afim recolher-se acampamento o Sr. Sant'Anna que leva uma barraca que deverá entregar no acampamento e um boi cargueiro com sua bagagem. Salvo ordens em contrario, como declarei José Izidoro, julgando interpretar vossas ordens e satisfazer ás exigencias do serviço, mandei-o entregar ao Sr. Miguel em 3 Buritys i 5 bois de cangalha frouxos e muitos pisados, incapazes proseguir viagem, alguns dos quaes talvez não escapem tal o estado de abatimento em que se encontram, permittindo a José Izidoro pôr cangalha em I 6 bois de carro que vinham com elle afim de poder conduzir as cargas para a frente; conforme vossas ordens, entregou elle ao Sr. Miguel os restantes i I bois da boiada de carro que trazia, toda em muito boas condições; com os bois magros mandei que ficasse o vaqueiro Severo Franco para delles tomar conta e tratar das pisadu- 


\section{7}

ras e feridas; tomei um boi de corte em Tres Buritys para matula do pessoal de José Izidoro; finalmente, apesar José Izidoro dizer-me que o havieis designado para ficar em Tres Buritys ajudando campeiros e verificando eu que para isso não fazia elle falta, resolvi que elle tomasse conta da tropa que era impossivel fazer seguir com o João de Deus (pela necessidade de aproveitar o curral afim de ensinar os bois de carro para servirem de cargueiros), determinando que elle hoje viesse o mais cedo possivel a José Bonifacio e amanhã se me apresentasse em Sete de Setembro. A necessidade de eu acampar nesse logar e despachar o Tenente Mello para o rio da Duvida com a urgencia que o caso requeria levou-me a dar esta ultima ordem ao José Izidoro, ao mesmo tempo que o deixava para trás.

Das cargas do rio da Duvida tres foram perdidas antes de José Izidoro tomar conta da tropa em Aldeia Queimada e quatro foram ali entregues para serem conduzidas pelos automoveis. Afim de completar a limpeza da picada a legua e meia daqui, ficam com o Sargento Satyro cinco foiceiros do meu contingente, os quaes terminado esse serviço se recolherão ao meu acampamento em Sete de Setembro. Apresento-vos por fim os cumprimentos de todo o pessoal superior da 2. ${ }^{a}$ turma aos illustres membros da I. ${ }^{a}$ turma especialmente ao Sr. Coronel Roosevelt por dever de gentileza e a vós como chefe e amigo que muito veneramos.

Vosso camarada, subordinado, amigo e admirador

(Assignado) Amilcar A. Botelho de Magalhães. 



\section{SUPPLEMENTO N. 22}

Acampamento n. 22 da 2. ${ }^{a}$ turma.

Cabeceira 7 de Setembro, 23 de Fevereiro de I9I 4. Sr. Coronel Rondon.

José Bonifacio.

Aproveitando a passagem do guarda fio Trindade que se recolhe a esse estação cumpro o dever de vos participar que o Tenente Vieira de Mello acompanhado de um inferior e I I praças desde hoje começou o trabalho de que o incumbistes no rio da Duvida.

Ao chegar ali não encontrara o regional Henrique, mas este appareceu hoje á tarde conduzindo em sua tropa de 7 burros os seguintes generos: 2 saccas de sal, I barrica de assucar, I/2 sacca de café, I caixa de feijão em vagens, 2 caixões de milho verde, I caixão de farinha de banana, I caixão com 30 latas de banha, I caixão com 25 latas de farinha Quaker, I caixa com 2 latas de assucar refinado, um encapado com 6 garrafas de succo de limão, 2 caixões de machados, 4 machados isolados - tudo conforme relação que mandou-me o Tenente Mello. 


\section{0}

Segundo informações que obtive uma das canôas é grande e bôa, as demais pequenas. Combinei com o Mello fazel-as tripular verificando a capacidade de cada uma, logo que elle termine o calafeto. Os generos a que me referi acima foram guardados pelo Tenente Mello no acampamento delle junto ao rio da Duvida e a tropa que os trouxe vein aqui para o meu acampamento afim de ser encostada com a minha, visto lá não haver pasto algum. Dos sete animaes o guarda Trindade conduzirá um para deixar ahi em José Bonifacio, pois é um animal doente e incapaz de prestar serviço.

Além das providencias que vos communiquei devo accrescentar que mandei deixar em Tres Buritys $\mathrm{I} 3$ bois cargueiros da minha tropa os quaes não estavam em condições de proseguir viagem, recebendo em troca ro outros em bôas condições.

Está acampado commigo a tropa do José Izidoro com todas as cargas do rio da Duvida, excepção de sete cujo destino já vos communiquei. Aguardo aqui a vossa chegada amanhã, tendo tido noticia de que deveis attingir hoje José Bonifacio.

O regional Marciano José dos Santos, aliás uma creança, abandonou o serviço em Tres Buritys, ficando ali sem nada me communicar, baseando-se infantilmente na concessão que fiz de dispensar o outro (Bernardino Varandas) e illudiu o Pedro Augusto, quando informou-o de que eu autorizara sua permanencia nesse logar.

Em relação ao serviço que o Mello tem a fazer nas canôas, devo adeantar-vos que, tendo só á tarde de hoje chegado ao rio da Duvida o Henrique, perdeu elle quasi todo o dia a procural-as em vão, 
estando afundadas as que deveria ter encontrado amarradas á ponte, segundo informações que me prestara o encarregado de José Bonifacio-Aquino. Não foram encontradas as canôas que ainda estavam em terra. Emquanto procurava as canôas, tratou elle de preparar a uns 500 metros do rio, um acampamento para a turma do Duvida, visto haver observado que o antigo acampamento ficava a meia legua de distancia.

Aqui tambem vou preparar uma area para o vosso acampamento "vis-à-vis " ao meu. Não conviria fazer seguir amanhã as cargas do rio da Duvida para lá?

Aguardando vossas ordens sempre desejoso de bem cumpril-as e apresentando respeitosas saudações a vós, ao Sr. Coronel Roosevelt e demais membros da I. ${ }^{a}$ turma, assigno-me vosso subordinado, amigo e admirador

(Assignado) Amilcar. 



\section{SUPPLEMENTO N. 23}

\section{Relação do pessoal que acompanhou a tropa do rio da Duvida e que foi aggregado á 2. ${ }^{a}$ turma até o acampamento da Commissão}

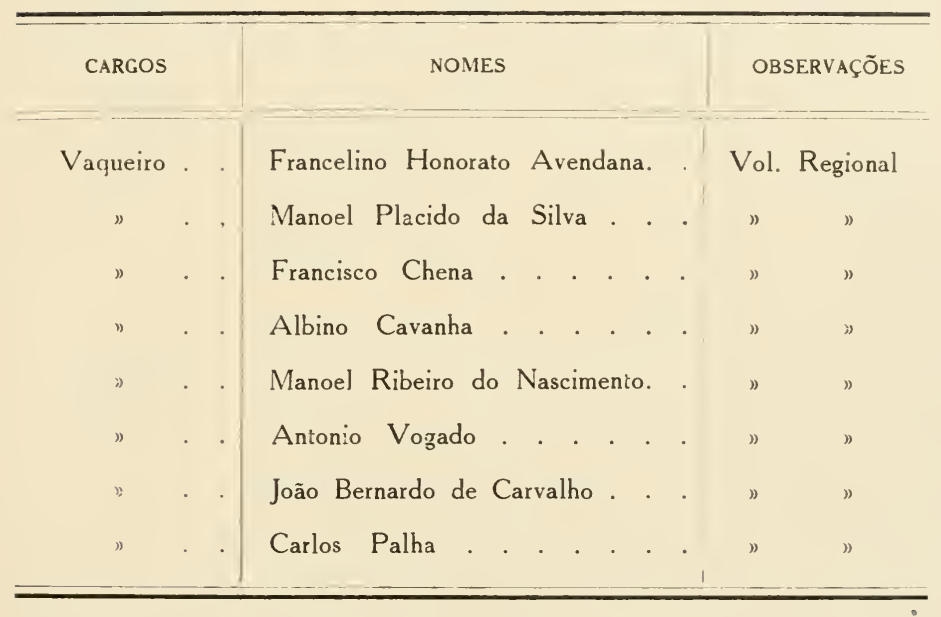





\section{SUPPLEMENTO N. 24}

\section{Relação do pessoal que acompanhou o}

contingente da $1 .^{\text {a }}$ turma e que foi transferido para a 2. ${ }^{a}$ turma em 27 de Fevereiro de 1914

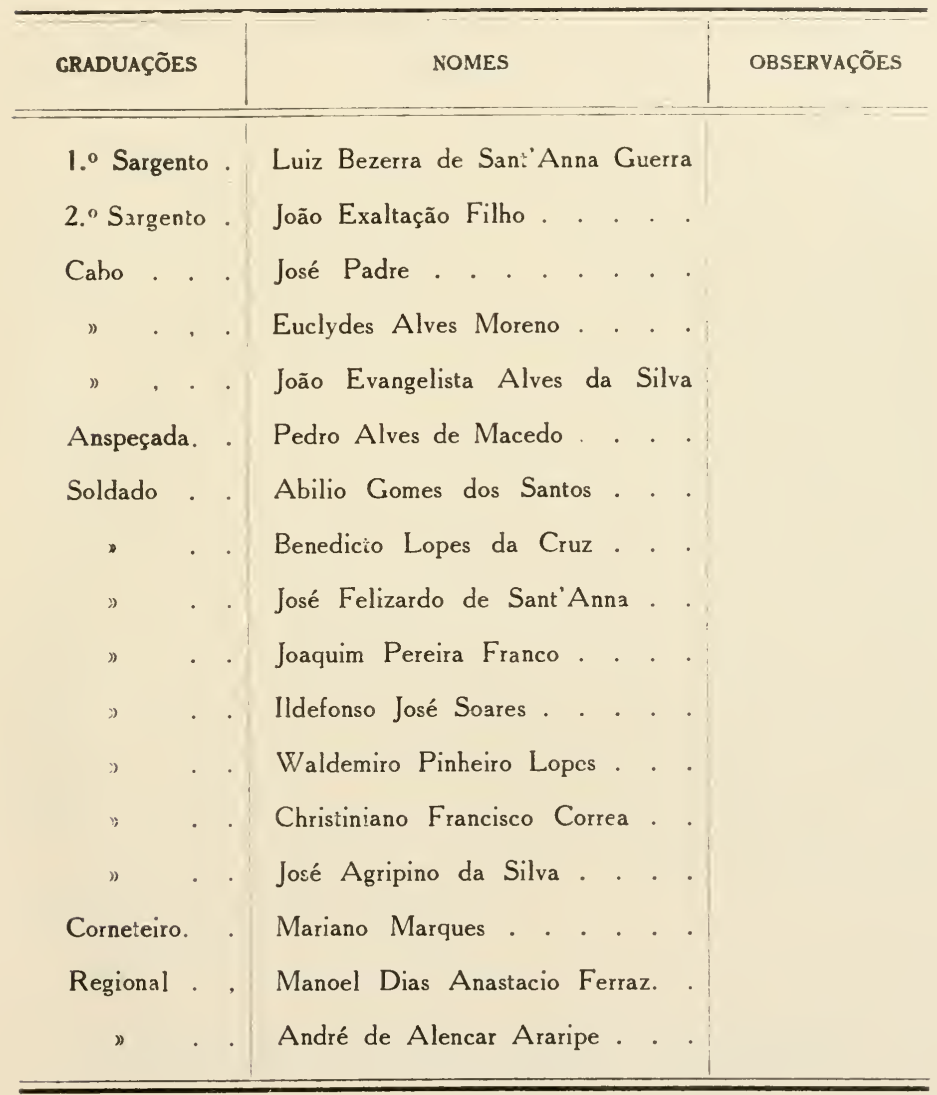





\section{SUPPLEMENTO N. 25}

Av. n. i 78 .

Barão de Melgaço.

Urgente.

$$
\begin{aligned}
& \text { Dr. Lauro Miuller. } \\
& \text { Ministro Exterior - Rio. }
\end{aligned}
$$

Participo V. Ex. chegada primeiro Março estação Barão de Melgaço segunda turma Expedição Roosevelt-Rondon da qual fazem parte actualmente naturalista americano Leo Miller e membros da commissão brasileira: Henrique Reinisch, geologo Dr. Euzebio Oliveira, Tenente Vieira de Mello commandante contigente. Demoramos aqui tempo necessario preparos descida embarcações rio Commemoração de Floriano e Gy-Paraná. Exploração rio Duvida iniciada dia 27 Fevereiro, descendo tres canôas e duas balsas Coronel Roosevelt, Coronel Rondon, Kermit Roosevelt, Capitão Medico Cajazeira, Tenente Lyra, naturalista Cherrie, além mais dezoito canoeiros conduzindo alimentação e bagagens reduzidas mais ou menos duas toneladas.

Estado sanitario ambas as turmas optimo ao iniciar respectivos serviços.

Respeitosas saudações

(Assignado) Capitão Amilcar Magalhães.

Chefe 2. ${ }^{a}$ turma. 



\title{
SUPPLEMENTO N. 26
}

\author{
Barão de Melgaço, i de Março de igi4. \\ Tenente Aureliano Coutinho. \\ Acampamento Jararaca.
}

Os companheiros da 2. ${ }^{a}$ turma da Expedição Roosevelt, eu, Tenente Vieira de Mello, Dr. Euzebio de Oliveira, naturtlista americano Leo Miller, taxidermista da Commissão Brasileira Henrique Reinisch e agrimensor Joaquim Horta (addido que vai tomar conta do pique ahi) enviamos os nossos saudares aos que tão stoicamente se batem neste sertão pelo progresso de nosso Paiz. - Aqui chegámos hoje á tarde e ficámos muito surprehendidos de não encontrarmos os batelões e canôas que nos devem servir para os serviços de levantamento do rio e transporte nosso ao Madeira pelo rio GyParaná. Mais ainda nos preoccupa esta falta porque estamos conduzindo um dos naturalistas americanos designado para o serviço zoologico no valle deste ultimo rio. O Sr. Coronel Rondon contava que aqui encontrassemos taes embarcações com os generos necessarios á nossa descida até o Madeira e levando em conta a demora nos levantamentos a fazer. De 
modo que resolvi mandar com urgencia um proprio até () Vosso acampamento afim de pedir-vos as mais urgentes providencias de tudo quanto estiver na alçada para que posamos deixar este paludoso logar onde estamos sem medico e com a responsabilidade da saude desse americano e dos soldados e regionaes que estão no nosso contigente sob o commando do l'enente Mello.

Caso nenhuma das providencias necessarias ao nosso serviço possa ser dada por vós, solicito o obsequio de fazer subir até aqui com a maxima urgencia pelo menos a canôa que costuma ficar aqui cm Barão de Melgaço, afim de que eu desça nella em busca dos batelões. Estes devem estar em Pimenta Bueno ha alguns dias, pois com muita antecedencia foram reclamados á firma Asensi pelo Sr. Coronel Rondon para aquelles fins.

Appello para a boa vontade do nosso companheiro para que, pela ultima vez agora, prepare no que for possivel o caminho por onde começaremos outra serie de viagens, agora fluviaes, tal como fez emquanto durou a nossa peregrinação, de Tapirapoan até aqui, por terra.

De ordem do Sr. Coronel Rondon deixaremos ahi no acampamento a maior parte desse pessoal, sendo que os regionaes para ahi vão muito legitimamente e as praças de linha, fazendo, parte do contigente officialmente posto á disposição da Expedição Roosevelt, ahi ficarão aguardando ordens do Sr. Coronel Rondon e prestarão serviços á Commissão de Linhas Telegraphicas até extincção d'aquella Expedição ou novas disposições do Chefe commum ás duas commissões. 


\section{1}

E sendo assim, se quizesse recebel-os immediatamente seria muito melhor para nós como para vós. - O Sr. Coronel Rondon autorizou tambem o Sr. Pedro Augusto de Figueiredo, encarregado da tropa de bois cargueiros que me acompanhou até aqui e nomeado encarregado de Campos Novos, para onde deve regressar com toda a urgencia, autorizou a receber dahi do acampamento os generos de que necessita, inclusive um pouco de feijão para plantar e os medicamentos que fôr possivel dar-lhe, tudo conforme as posses do deposito ahi ; e para despachal-o peço responder-me em que condições podeis attender a esse fornecimento, sendo que tenho meu ainda algum genero que poderia ceder se me garantisseis não ter de lamentar minha "franqueza ".

A ordem do Coronel é tambem fazel-o voltar (elle Pedro Augusto) com toda urgencia, afim de salvar a boiada e os burros de montaria que sem pasto aqui morreriam ou não aguentariam o regresso.

Peço-vos todas as informações que me puderdes dar em beneficio de nossa missão e a possivel urgencia na resposta.

Recado do vosso camarada e admirador

(Assignado) Capitão Amilcar Magalhães.

Chefe da 2. ${ }^{a}$ turma da Expedição Roosevelt. 



\section{SUPPLEMENTO N. 27}

Barão de Melgaço.

Av. n. I94.

Urgente.

Tenente Coutinho.

Acampamento Jararaca.

Não tendo sido possivel subir hoje o rio áfim de fazer levantamento desde o passo Parabens porque, inclusive, acabamos de naufragar pouco a montante deste logar, peço-vos com urgencia fazer subir immediatamente o batelão que ia descer d'ahi com o João de Deus, afim de nelle descermos para Pimenta Bueno.

A pressa com que vos escrevo não permitte ser mais extenso.

Abraços e agradecimentos do camarada e admirador

(Assignado) Amilcar. 



\title{
SUPPLEMENTO N. 28
}

\author{
IO de Março de I9I4. \\ Tenente Ficira de Mello.
}

Pimenta Bueno.

Meu distincto camarada. Escrevo-te antes de partir em busca dos recursos de que ha necessidade para que a nossa turma possa descer o Gy-Paraná. Infelizmente até hontem esperei aqui os batelões da casa Asensi e elles cá não appareceram. Espero que me faças a justiça de acreditar, assim como os demais companheiros da 2." turma da Expedição, especialmente o Sr. Miller, naturalista americano, que a minha descida na frente, em pessima canôa que aqui encontrei do Sr. Mascarenhas, representante da firma Asensi, descida essa, ainda mais, effectuada quando deixo para trás parte de minha bagagem, da qual muita cousa me tem feito já falta, não visa abandonar os meus companheiros mas ao contrario, apressar a vinda de recursos ao mesmo tempo que o meu avanço permittirá sem prejuizo da velocidade da descida - velocidade que todos nós desejamos que seja maxima - fazer senão todo, ao menos o maximo do serviço que me foi determinado pelo Coronel Rondon. 
Assim pensei, egualmente, quando resolvi deivar Barão de Melgaço, não demorando mais que algumas horas no acampamento de Jararaca, afim de vir apressar aqui a subida dos batelôes, que os devem trazer dahi até este logar.

Deves comprehender, e fazer com que os outros companheiros comprehendam, que seria um abuso de consequencias más para a Commissão Telegraphica, arrebatarmos do serviço qualquer desses dous batelóes que são a tropa que conduz tudo de um acampamento para outro, material de construcção e munição de bocca.

Ponhamo-nos no caso do Coutinho e reflictamos com os mesmos argumentos com que nos procuramos sempre prevenir contra qualquer falta de alimentação durante nossa marcha de Tapirapoan a Barão de Melgaço, e havemos todos de concordar que o que se vai fazer é o melhor, de accordo com as circumstancias do momento. Descerei na frente, farei esforços para que encontrem aqui os batelões para descer até o ponto em que ha lancha para transporte; em seguida irei fazendo os levantamentos que fôr possivel fazer de modo a não exceder a nossa chegada a Manáos dos 12 dias de Abril.

Lá em baixo antes de sahirem do Gy-Paraná provavelmente todos estaremos juntos novamente e se quizerem podem seguir na minha frente, invertendo-se ahi então a columna, proseguindo eu na retaguarda afim de concluir esse serviço e tocando vocês para Manáos sem mais demora.

Durante a descida deves permittir inteira liberdade ao Sr. Willer para elle fazer suas collecções e 
ter tempo de preparar seus animaes; todavia sempre que fôr possivel reunir o util ao agradavel, marcharás com a maxima velocidade e no batelão irá elle preparando os seus animaes. O mesmo em relação ao Reinisch, cuja collecção, na hypothese prevista de vocês passarem na minha frente, fica ao teu cuidado arrecadar e despachar para onde elle julgar mais conveniente, Museu ou Escriptorio da Commissão - no primeiro caso convindo avisares o Jaguaribe para que assista á abertura dos caixões e o relacionamento como representante do Chefe da Expedição, passando um telegramma quando fôr despachado tudo.

Por todos os barracões do Asensi encontrarás ordem franca para te supprires do que fôr necessario, deixando documento claro de que tirarás copia para o archivo da Expedição e conveniente escripturação.

Seguem commigo agora o João da Cruz, o cabo Joviniano e o soldado Paixão ; comtigo devem descer os demais cuja relação está em teu poder e mais os regionaes e pessoal aqui despachado da Commissão, a maior parte invalidos que vão fugindo da morte. Não os levo commigo porque a chalana em que vou descer os não comporta absolutamente.

A tua disposição para descer deves aqui encor.. trar, ao chegares cá, os dous grandes batelões, em um dos quaes accumularás todos os soldados, ficando para os officiaes o outro - o melhor delles.

$\mathrm{O}$ encarregado que vem com essas embarcações é de toda confiança da casa e receberá ordem de ficar á tua disposição ; assumirás o commando geral 


\section{8}

das tropas e recommendo-te a maxima prudencia e muta diplomacia e paciencia com o Miller, tendo sempre em vista a nossa funçãa aqui em relação á commisiño americana fazer o mais possivel a a contade delles. Tudo quanto elle ou o Reinisch julvarem util comprar para suas collecções ou para execução de seus serviços deves fazel-o, declarando sempre a importancia - por extenso nos documentos, ") animal, pelle ou lá o que fôr e reservando copia como disse linhas atrás.

Convem levares presentes daqui, como eu vou fazer. para deixar nos pontos em que os indios I'auatês, que agora começam a falar comnosco e trocar presentes, costumam fazel-o em giráos que construiram "ad-hoc ". Os objectos indigenas sempre que fôr possivel devem ser irmãmente divididos, pelo Miller e Reinisch, se este julgar uti1 ao nosso museu ou pelo Miller e você para deixares o teu quinhão em Manáos á disposição do Coronel Rondon, caso o Reinisch nada encontrar de interesse relativo á sua especialidade. Acredito que farás melhor viagem do que fiz de Barão de Melgaço até aqui e que melhor ainda será a que irás fazer daqui para o Madeira até o meu encontro.

Pelas informações que tenho colhido devo escolher uma das pontas do dilemma: levantar o resto do Gy-Paraná da Bôa Vista á fóz ou levantar os 3 affluentes Anary, Machadinho e Preto. Qualquer dos dous casos comporta um serviço de quasi um mez!

A exploração de qualquer destes 3 affluentes é mais com o objectivo do levantamento, porque em todos elles até muito acima existe já seringueiro 
collocado e trabalhando! Não seria pois uma verdadeira exploração, porque não se comprehende que se vá explorar um rio já habitado! Convem explicares isto ao Sr. Miller, pondo-me eu em todo caso á disposição delles para "fingirmos " de grandes exploradores em qualquer dos 3 rios, segundo o ponto em que nos encontrarmos: se nos encontrarmos antes do Anary, poderemos penetrar por qualauer dos tres, á escolha delle. Entretanto para a Expedição propriamente entendo de preferencia abandonar os affluentes e levantar a parte que falta do $\mathrm{Gy}$, completando assim a planta do percurso todo da $2 .^{a}$ turma : não te parece? Se me quizeres acompanhar e praticares nesse simples serviço, deixo inteiramente á tua vontade resolvel-o, sendo certo que dous operadores darão um rendimento superior. Se eu puder, farei o serviço completo, começando pelo Anary: depende isso dos recursos que a casa Asensi me entregar para tal fim. Do que fôr resolvendo á proporção que os casos se apresentarem dar-te-ei conhecimento por escripto para teu governo.

Estava eu neste ponto quando appareceram as luzes do primeiro batelão Asensi, ouvindo-se os 2 tiros com que costumam annunciar a sua chegada; em seguida veio outro, seriam umas I I horas da noite.

Seguirei amanhã em um delles com todo pessoal da Commissão que desce e aqui ficará o outro para vocês 5 e 8 praças nelle descerem, pois comporta elle todos perfeitamente.

O encarregado do batelão como te disse tem ordem de se apresentar e ficar ás tuas ordens; tudo quanto todos quizerem deve ser ordenado por ti, nada 


\section{0}

se fari sem o teu consentimento ou ordem expressa. Nu caso contrario dar-se-ia a anarchia e no nosso regimen de serviço militar o responsavel é sempre o " official " mais graduado, exceptuando a Guarda Nacional e os estrangeiros... E bôa viagem; até breve. Abraços ao Euzebio, recommendações ao Sr. Miller e ao Reinisch, como ao Adelino.

Abraça-te com toda camaradagem e sympathia o camarada amigo e admirador

(Assignado) Amilcar Magalhães. 


\section{SUPPLEMENTO N. 29}

Av. n. 2 I 6.

I 6 de Março de I9ı.

Sr. Coronel Rondon.

Manáos.

Barracão Monte-Christo, á margem esquerda do rio Gy-Paraná, i6 de Março de igI4.

Participo-vos que fiz entrega de cincoenta mil réis em dinheiro ao Sr. Eduardo Feliciano Alves, encarregado deste barracão afim de serem pagos como gratificação ao pessoal de uma canôa da casa Asensi que soccorreu-me assim como aos 4 homens da minha tripulação no naufragio que assignalou a minha passagem pelo estirão de Mareçal, sendo essa quantia retirada, por conta das despesas da Expedição, dos vencimentos de dous regionaes que por esquecimento deixei de entregar-lhes no acampamento da commissão, e cujo saldo entregarei em Manáos ao Capitão Marinho-se outro imprevisto não desfalcar mais essa quantia. Peço vossa approvação para esse meu acto. Aproveitando o ensejo participovos que com auxilio de uma chalana do serviço do acampamento e com uma canôa que retirei da bocca do rio Francisco Bueno, parti no dia 4 de Março pelo Commemoração acima, gastando 45 minutos para 


\section{2}

vencer o trecho do rio entre o arame que o atravessa defronte a Barão de Melģaço e o extremo da area roçada a montante, o que bem poderá dar ideia da velocidade quasi negativa com que iamos subindo. l) epois de varias ameaças a nossa canôa rodou sobre uma ramada e virou, sendo, arrojados á forte correnteza () Dr. Euzebio (que eu convidara para ir commigo ás cachoeiras, que são 8, incluindo a do passo Parabens, no duplo interesse de seu estudo geologicr e da rapidez com que seria feito o serviço com dous operadores quando eu descesse com o levantamento do Parabens para Barão de Melgaço) c 4 homens da tripulação os quaes, todos, á excepção de $u$ m. não sabiam nadar e valeram-se primeiro do proprio galho partido e depois, quando este quebrou-se com o peso delles, de um cipó grosso donde o Sr. Dr. Euzebio foi retirado já exhausto e tendo bebido muita agua. Para augmentar-lhes a angustia um dos soldados ao pegar-se ao tronco da arvore poz a mão sobre uma enorme cobra que ali estava enrolada e que ficou a pique de mordel-o, em lembrança do que dei a sua pelle ao Reinisch. Segundo a opinião do Tenente Mello essa cobra é egual á que victimou o Joaquim Parecis, segundo outras opiniões é jararaca, ou jararacussú. Deante do occorrido resolvi então que o Dr. Euzebio ficasse (estavamos a minutos por terra) em Barão de Melgaço e assim as bagagens todas, afim de aliviar as canôas, seguindo todos inclusive eu apenas com a roupa do corpo e generos para Io dias; ao tornar effectiva a minha resolução verifiquei que dispunhamos apenas de 3 remos, os demais tendo rolado pelo rio abaixo. Aliás estes remos haviam-me sido cedidos de um dos 


\section{3}

2 batelões da Commissão que trabalham ahi entre Barão de Melgaço e Pimenta Bueno. Era impossivel subir assim porque, além de tudo, o rio Commemoração, de Barão de Melgaço para montante até onde fui, é uma corredeira interminavel sem um remanso. A canôa pequena nos logares de correnteza mais forte só subia puxada pelos ramos da margem porque além de pesada e de não comportar mais que dous homens, estes só se mantinham nella movendo-se com cuidado, devido, á sua instabilidade: esta ubá "especial ", quando desci de Pimenta Bueno, deixei como presente, junto a uma outra que - Tenente Amarante deu aos indios Pauatês, defronte do "porto Amarante". (Entre parenthesis: deixei muitos presentes que trouxe de Pimenta Bueno na "fortaleza de Santa Cruz " e em outros giráos que os Pauatês tem construido para trocar brindes. Se ainda a não tivestes por melhor portavoz dou-vos a bôa nova, de que esses indios chegaram á fala no Gy-Paraná, vindo ao batelão da casa Asensi onde viajava o cabo Joviniano e pedindo tudo que viam). Mas, continuando a minha prolixa narrativa, reconhecendo a impossibilidade de subir com taes recursos, voltei a Barão de Melgaço, onde deixei o Dr. Euzebio com o resto do pessoal da turma, conservando os soldados indispensaveis ao nossỏ serviço e tendo recolhido no dia seguinte á minha chegada todos os outros ao acampamento da Commissão, almocei e parti com o levantamento rio abaixo, parando apenas um pouco no acampamento Jararaca, de onde parti no dia seguinte, mesmo pela necessidade de providenciar sobre a descida da turma, pois na hypothese de executar o levantamento 
desde Parabens fiz o inspectur João de Deus seguir no batelão que veio a meu pedido para Barão de Melgaço, visto que o outro deveria chegar dentro de uma semana - tendo em consideração tambem não perturbar o serviço de abastecimento do acampamento da Commissão de Linhas Telegraphicas. O Tenente Coutinho, que é uma energia varonil mettido em pallido e franzino arcabouço, prestou-me todo o auxilio com uma boa vontade e camaradagem dignas de nota, o que permittio-me uma serie de providencias e a effectuação do levantamento do rio Commemoração desde Barão de Melgaço até Pimenta Bueno. Concluido este serviço deixei um batelão Asensi em Pimenta Bueno e desci com outro até Bôa Vista onde o Sr. Mascarenhas, procurador e representante da firma Asensi, sempre com a maxima bôa vontade entregou-me 3 canôas para o levantamento do Gy e 8 homens seus, pois nem era bom pensar em tripular as canôas com o meu pessoal que nem remar sabia. Em Pimenta Bueno deixei instrucções ao 'Tenente Mello, a quem incumbira de chefiar interinamente a turma, providenciando de accordo com as vossas ordens, afim de descer ao meu encontro, seguindo eu na frente porque iria adeantando o serviço de levantamento do rio e providenciando para que tivessem elles sempre transporte ininterrupto até Calama. Communiquei nessa carta ao Tenente Mello que, tendo conhecimento de que nos 3 rios a levantar Anary, Machadinho e Preto a firma Asensi tem já seringueiros collocados e trabalhando, devia elle levar esse facto ao conhecimento do Sr. Miller que julgava fazer commigo a exploração desses riós ou pelo menos de um, deixando em 
todo caso que elle Miller decidisse se queria subir qualquer delles, para o que me punha á disposição delle, embora não se tratasse de zona desconhecida. Em todos os barracões irá o Tenente Mello encontrando ordem para requisitar o que for preciso. Desci com o levantamento no dia 12 ao meio dia do barracão Bôa Vista, onde, eu havia chegado ás 9 horas, am. desse mesmo dia, ahi almoçando e preparando as canôas de levantamento. Levantei o rio até aqui acima, em um tal estirão do Mereçal, onde como vos disse em começo, alagou-se a canôa em que eu vinha com os instrumentos, perdendo-se a canôa, o telemetro Fleuriai, a bussola prismatica, thermometro de maxima e minima, barometro, minha pistola Coltz, minha capa impermeavel, caderneta com observações meteorologicas de Tapirapoan edolorosa perda! - a caderneta do levantamento, onde havia um trecho do Commemoração com sondagem, calculos de descarga, secções transversaes delle e do Pimenta Bueno, velocidades determinadas com o fluctuador e o trecho todo do Gy-Paraná desde igarapé Bôa Vista até Mereçal. Felizmente, aproveitando as "horas vagas" eu vinha desenhando o croquis dos meus levantamentos, de modo que fiquei com a planta completa do Commemoração, planta digo mal, "croquis " desde Barão de Melgaço a Pimenta Bueno, sem comtudo registar nella as sondagens e qualidade do terreno no fundo (pedra em geral, muito poucas vezes barro vermelho).

Do levantamento feito no $\mathrm{Gy}$ eu tinha desenhado apenas I 4 I estações e estava aqui já com quatrocentas. Nestas condições, tendo perdido remos 


\section{6}

(c) uma canôa, assim como os instrumentos do serviço. desci, com todo o pessoal, pois que felizmente nenhum desastre pessoal houve a lamentar, apesar de só eu saber nadar, e vim para aqui (Monte(hristo) onde arranjei outra canôa e reforcei as guarnições. Requisitei outro piloto pois á impericia do meu é que se deveu o desastre, afim de retroceder amanhã até o igarapé Bôa Vista onde vou buscar novas ferramentas para o meu trabalho, refazendo o levantamento desde antes de Monte-Carlo até aqui, pois ao passar pelo barracão daquelle igarapé vi ahi um telemetro egual ao meu e uma bussola ao lado de um transito Gurley, todos instrumentos ahi deixados pelo Tenente Nicolau para guardar. Significa isto retardar de mais de oito dias a minha chegada a Manáos quando eu tinha os dias contados para attingir o Rio em epoca determinada. São as contingencias do serviço e me conforto contemplando os vossos actos, mas haveis de comprehender como me sinto constrangido com a perspectiva de não estar em meu lar em periodo em que a minha presença ali era indispensavel (fala aqui o amigo não o subordinado) quando me poderá pesar a responsabilidade de um grande mal. Neste sentido telegraphei para o Rio ao irmão de minha senhora para que empregasse todos os meios de occultar-lhe a minha demora mas que certamente excederia o prazo em que devia estar no Rio, por um imprevisto que preferi não communicar.

Este telegramma será levado pelo Capitão Jorge Tinoco por quem passei hontem com o levantamento e a cuja frente passarei antes de chegar ao igarapé Bôa Vista. No momento do naufragio o cabo 
Joviniano salvou a minha mala, dentro da qual estavam os croquis a que me referi acima; os 4 homens da canôa salvaram-se agarrando ao galho contra o qual foi bater a canôa e eu salvei-me nadando vestido para a margem onde, bastante cançado - pois a correnteza era muito forte ahi e eu não sou grande nadador-agarrei-me a um cipó e, puxando o relogio do bolso vi que estava andando e marcava duas horas e dez minutos da tarde. A's 2 e i 5 minutos pm. chegou a canôa que me colheu, quando estava descançando já e procurando um bom logar para subir á margem que eu via a poucas braçadas, mas, separada e defendida pela corredeira que no momento parecia ter Ioo metros de velocidade por segundo.

Regressarei pois amanhã e espero encontrar a turma descendo; pretendo continuar separado da turma, pois o Tenente Mello ficará com o Miller e dará todas as providencias necessarias, seguindo eu depois. Com as minhas respeitosas saudações abraço-vos como amigo, subordinado e admirador

(Assignado) tmilcar. 



\section{SUPPLEMENTO N. 30}

Av. n. $22 \mathrm{I}$.

2I. de Março de igi4.

Sr. Coronel Rondon.

\section{Manáos.}

Acampamento junto á barraca Monte Carlo á margem esquerda do rio Gy-Paraná, 2 I de Março de igi4.

Acabo de chegar ás 5 horas e 30 minutos pm.. de regresso do igarapé Bôa Vista até onde subi em busca de novos instrumentos para proseguir e refazer a parte perdida do levantamento do Gy-Paraná.

Infelizmente foi inutil o meu esforço pois ali não havia apparelhos com que eu pudesse fazer o serviço, na canôa que eu dispunha para esse fim. Eu não sabia os instrumentos que lá estavam ; olhara-os distrahidamente e abrira justamente a caixa do telemetro Fleuriai para mostrar que era egual áquelle com que eu trabalhava, por conhecel-o bastante. Havia um transito Gurley ao lado delle. mas onde eu suppunha encontrar uma bussola, egual a que levastes no rio da Duvida, estava uma stadia Gurley.

Além de tudo, não tendo nunca trabalhado com esse stadiometro e estando sem um livro para orien- 
tar-me, não havendo na caixa o livreto com indicacões relativas á pratica do apparelho, receei muito naturalmente que além da canôa o operador fizesse um máo serviço que não deveria merecer fé. E assim (heguei, vi e fui vencido... Foi uma grande decepção para mim e o meu maior desejo seria voltar do Rio e vir eu mesmo executar não só o levantamento do (iv-Paraná como dos affluentes que indicastes Anary, Machadinho e Preto, e de outros que ainda não foram levantados, até ás cabeceiras, ficando depois á vossa disposição para auxiliar-vos no serviço da Commissão de Linhas Telegraphicas. Entretanto, como tendes conhecimento pessoal, a minha situação especial obriga-me a nâo promettervos cousa alguma neste sentido, limitando-me a affirmar-vos que, baseando-me na primeira excepção aberta e não tendo sido possivel concluir agora o serviço que me havieis designado, por circumstancias independentes de minha vontade, affirmo-vos sob minha palavra, que empregarei todos os meus esforços para que mais uma vez possa eu vangloriar-me de voltar a servir sob vossas ordens.

E' a esperança que me resta nesta deploravel inactividade a que fico subordinado até terminar minha viagem. Em tempo opportuno vos tornarei a escrever. Augurando-vos toda a sorte de felicidades no vosso serviço actual e no da linha telegraphica, apresento-vos as mais respeitosas saudações como vosso subordinado, admirador e amigo

(Assignado) . milcar. 1. Botelho de Magalhães. 


\section{SUPPLEMENTO N. 31}

Av. n. 196.

$$
\text { Manáos, } 4 \text { de Abril de rol } 4 .
$$

Urgente.

$$
\begin{aligned}
& \text { Dr. Lauro Miuller. } \\
& \text { Ministro Exterior - Rio. }
\end{aligned}
$$

Participo V. Ex. segunda turma Expedição Roosevelt acaba chegar rio Madeira ficando nuturalista americano Miller e taxidermista Reinisch no porto Calama terminando preparo respectivas colleções zoologicas.

Geologo Dr. Euzebio acompanhado Tenente Mello seguiram Porto Velho objecto importante estudo cachoeira Guajará-mirim suas congeneres, regressarão Calama dia seis recolhendo-se então Manáos toda turma. Apesar toda travessia sem medico tornada mais penosa epoca chuvas, estado sanitario optimo.

Saudações cordiaes

(Assignado) Capitão Amilcar Magalhães.

Chefe da 2. " turma Expedição Roosevelt. 



\section{SUPPLEMENTO N. 32}

Av. n. 230.

6 de Abril de r 9 I 4.

Sr. Coronel Rondon.

Manáos.

Acabo de chegar a Manáos e cumpro o dever de communicar-vos que ficaram em Calama, gentilmente hospedados pelo Dr. Carlos Asensi o Sr. Miller e o taxidermista Reinisch, conforme desejos manifestados pelo primeiro, com o fim de preparar melhor as collecções zoologicas que já possuem e completal-as com alguns specimens que fazem questão de adquirir e ainda não haviam conseguido até minha partida dali no dia 2 do corrente a bordo do paquetinho "Rio Curuçá ". Seguiram para Porto Velho o Tenente Mello e o Dr. Euzebio que vai estudar Guajará-mirim conforme vossas ordens: ambos regressarão no proximo vapor que hoje ou amanhã deverá passar por Calama, onde embarcaram os dous outros membros da turma, recolhendo-se a Manáos com a unica praça que ali ficou para servir ao Sr. Miller, tendo o Tenente Mello enviado as demais praças para Manáos com carta ao Capitão Marinho e vindo commigo tres outras que mandei 


\section{4}

apresentar á Inspecção. Com este aviso deixo-vos aqui em Manáos os dous blocos de aviso e correspondencia minha desde que parti do rio da Duvida, sendo imprescindivel que tomeis o trabalho de ler tudo isto, porquanto ha varias providencias que dependem ainda de vossa approvação, outras que representam a prova de haver cumprido ordens que me destes verbalmente e outras finalmente referentes a recados verbaes que recebi por intermedio de terceiros e, cuja authenticidade, convem verificardes.

Aproveito o ensejo para communicar-vos que foi registada toda a correspondencia do Coronel Roosevelt, dos demais membros e da Commissão Americana, achando-se os recibos á disposição do Tenente Mello na casa Asensi \& C., nesta praça, firma que encarregou-se de tal serviço, fazendo uma despesa total de que deverá ser deduzida a importancia dos sellos que eu já havia applicado a diversos enveloppes desses, mas que não sei a quanto monta.

Deixo aqui uma carta de despedida que dirigi ao Sr. Coronel Roosevelt em máo francês, talvez mesmo orthographicamente errada á falta de um diccionario; outra que vos dirigi no mesmo sentido e uma ao Kermit, pedindo que apresente minhas despedidas aos demais membros da Commissão Americana. Todas estas cartas eu vos deixo abertas muito de proposito para que vos scientifiqueis de seu conteudo especialmente quanto á ultima cujos termos parecem uma contradicção com outra que vos dirigi de Monte Carlo e que colloquei no mesmo enveloppe da que aqui deixo tambem ao Lyra; mas que, o simples facto de chamar para o caso a vossa 


\section{5}

esclarecida attenção, dispensa-me de commental-a, reduzindo a zero a deslealdade apparente que o facto encerra, certo de que resolvereis o enygma com justiça para mim. Peço-vos não esquecerdes de communicar-me para o Rio o plano geral do vosso relatorio assim como a remessa de todos os documentos da despesa de vossa turma em Manáos e durante a viagem do Duvida até aqui, chamando minha attenção e a do Malheiros para alguma despesa que nos tenha escapado de assignalar. Seria favor tambem verificardes se não houve alguma omissão na lista do pessoal que desceu o rio da Duvida, pois que, a relação que o João Albano fez foi por mim corrigida da falta do nome do Antonio Parecis e como houve essa falha póde ter havido outras e neste caso será tambem necessario corrigir a ordem do dia correspondente. Pretendo deixar a copia das alterações vossas, minhas, do Lyra, do Cajazeira e do Mello até onde as conheço, convindo que, depois de assignadas e completadas por vós na parte referente ao rio da Duvida. sejam ellas remettidas em tres vias ao escriptorio da Commissão no Rio, onde o Tenente Jaguaribe as fará lançar no livro competente antes de passal-as ao Ministerio da Guerra. Salvo erro ou engano deixei no Acampamento de Jararaca 45 praças inclusive inferiores e regionaes, de todo 0 contingente com que afinal attingi Barão de Melgaço, fazendo-os acompanhar de uma relação nominal que foi assignada pelo Tenente Mello e por nós confeccionada com o devido cuidado, relação que foi entregue ao Tenente Coutinho. Taes são por ora as informações que julguei uteis e necessarias prestar-vos por esta vez, ao correr do lapis. 


\section{6}

A proporção, que me fôr lembrando outras, vol-as irei transmittindo.

Desejoso de saber do resultado de vossa exploração com o Coronel Roosevelt, faço votos de coração para que termineis com estrondoso exito mais este importante serviço que só a vós poderia ser confiado com segurança.

Vosso admirador, subordinado e amigo

(Assignado) Amilcar Armando Botelho de !) agalhães. 


\title{
SUPPLEMENTO N. 33
}

\author{
Manáos, le i I Avril igr4. \\ Mr. Le Colonel Theodore Roosevelt.
}

Je vous écris sans l'aide d'un dictionaire et je compte d'avance sur votre bienveillance pour excuser les fautes commises dans cette lettre.

Ayant une affaire d'urgence a Rio et, en profitant de la permission que vous m'avez accordée et d'après l'ordre reçu de Mr. le Colonel Rondon, je partirai demain vers cette ville.

Mais avant de "retourner a Madame ", c'est mon devoir laisser ici avec mon congé mes remerciements pour la façon si aimable dont vous m'avez distingué, au-dessus de mon propre mérite, pendant le service comme attaché a l'Expédition Scientifique Roosevelt-Rondon, service que m'a permis l'honneur de votre connaissance personelle.

En vous assurant ma très haute et sincère sympathie je resterai à votre service à Rio, rue Barroso 2 I 6.

Excusez les fautes du

Capitaine Amilcar Magalhães. 



\title{
SUPPLEMENTO N. 34
}

\author{
Manáos, Abril de i9i4.
}

Caro Chefe e amigo Coronel Rondon.

Com immenso pesar de partir antes de vossa chegada a Manáos, apesar da permissão que me concedestes para tal fim, apresento-vos por este meio as minhas despedidas, reiterando aqui os meus protestos de estima e consideração que cada vez mais se accentuam em meu espirito quanto mais observo os vossos actos, deixando ao mesmo tempo consagrados pela mesma forma o meu agradecimento sincero e o meu profundo reconhecimento pela honra que tive de servir sob vossas ordens, ainda que por curto espaço de tempo, pedindo-vos desculpa de alguma falta que haja commettido e da insufficiencia com que exerci o cargo que me confiastes por vossa bondade.

Infelizmente com o meu naufragio perdi varias notas e relações que devia aqui deixar-vos, em todo caso, procurarei transmittir-vos as informações de que podeis carecer e que eu vos puder dar quanto á 2. " turma e aguardo no Rio vossas ordens para fazer o relatorio da Expedição.

Vosso amigo, subordinado e admirador (Assignado) Amilcar A. B. de Magalhães. (Rua Barroso 2 I6 - Copacabana.) 



\title{
SUPPLEMENTO N. 35
}

\author{
Manáos, Abril de i9r4.
}

\section{Ilen caro Kermit.}

Partindo hoje para o Rio de Janeiro deixo-te aqui o meu abraço de despedida e peço-te transmittir o meu adeus a cada um dos membros da Commissão Americana. Por dever de gentileza que eu cumpriria com prazer pela sympathia que me despertou a pessoa do Sr. Coronel Roosevelt, eu tinha obrigação de esperal-o antes de partir para apresentar-1he pessoalmente as minhas despedidas, mas, chamado com insistencia e, tendo mesmo urgencia de chegar á minha casa aproveito a delicada permissão que elle me deu e retiro-me deixando por esta forma as minhas excusas.

Sei que te casarás breve em Madrid e quem sabe se não te irei ali visitar? Se eu conseguir a minha nomeação para membro da Commissão de Compras que o Brasil mantem na Europa para acquisição de material bellico do nosso Exercito, nomeação que vou solicitar agora quando chegar ao Rio, em Junho ou Julho espero estar em Paris e neste caso, se estiveres em Madrid, muita satisfação terei em rever o meu companheiro de Expedição. Tens agora no Rio a rua Barroso 2 I6 - Copacabana uma casa ás tuas ordens.

$E$ adeus! Abraça-te o amigo

(Assignado) Amilcar A. B. Magalhães. 



\section{SUPPLEMENTO N. 40}

\section{Quadro comparativo das rações por praça}

\begin{tabular}{|c|c|c|c|c|}
\hline \multirow[b]{2}{*}{ GENEROS } & \multicolumn{4}{|c|}{ TABELLAS } \\
\hline & $\begin{array}{c}\text { JACY- } \\
\text { PARANÁ } \\
\text { A }\end{array}$ & $\begin{array}{c}\text { COMMISSÃO } \\
\text { EM } \\
\text { TAPIRAPOAN } \\
\text { B }\end{array}$ & $\begin{array}{l}\text { EXPEDIÇÃO } \\
\text { SCIENTIFICA } \\
\text { KOOSEVELT- } \\
\text { RONDON } \\
\text { C }\end{array}$ & $\begin{array}{l}\text { COMMISSÃO } \\
\text { EM } \\
\text { PONTE DE } \\
\text { PEDRA } \\
\text { D }\end{array}$ \\
\hline Arroz . . & 0,16 & 0,16 & 0,20 & 0,20 \\
\hline Assucar . . & 0,050 & 0,040 & 0,050 & 0,100 \\
\hline Banha . . & 0,030 & 0,040 & 0,050 & 0,050 \\
\hline Café em grão. & 0,050 & 0,040 & 0,050 & 0.150 \\
\hline Carne secca. & 0,360 & - & 0,250 & 0,200 \\
\hline » fresca. & - & 0,300 & 0,500 & - \\
\hline Farinha. . & 0,33 & 0,40 & 0,50 & 0,40 \\
\hline Feijão . . . & 0,28 & 0,26 & 0,30 & 0.30 \\
\hline Mate . . & - & - & - & 0,016 \\
\hline Sal . . . & - & - & - & 0,01 \\
\hline
\end{tabular}

OBservações. - A Tabella da Expedição era a que conferia as rações mais elevadas em todos os generos, embora apparentemente seja ella inferior nas quantidades marcadas de assucar e café em relação á tabella $D$, como nas de carne secca em relação á tabella $A$, o que na realidade não se passava, pois que simultaneamente á carne secca consumia-se muita conserva em latas, ao lado do assucar das praças consumia-se para a meza dos officiaes assucar de beterraba em tablettes, e o consumo de café e chá para os officiaes não obedecia tão pouco a limitação de tabella alguma. 



\section{SUPPLEMENTO N. 41}

Tabellas de generos adoptadas pela Commissão de Linhas Telegraphicas Estrategicas de Matto=Grosso ao Amazonas, em Tapirapoan, e pela Expedição Scientifica Roosevelt=Rondon RAÇÃO DIARIA PARA CADA PRAÇA

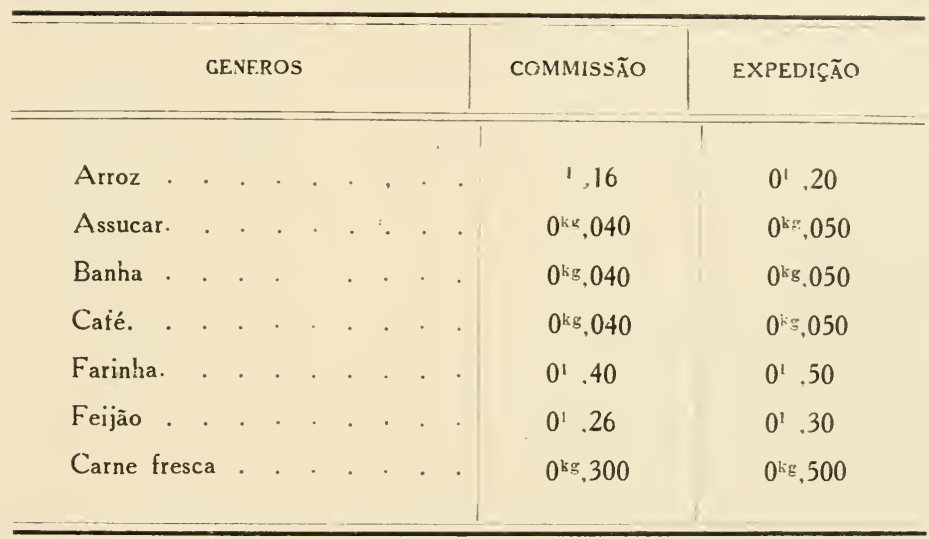

OBSERVAÇõEs. - Embora fiscalizando para que não houvesse desper. dicio, fornecia-se o sal á proporção das necessidades e independentemente de tabella.

- Além desses generos de primeira necessidade, fornecia-se ern cada domingo $0^{m}, 25$ de fumo em rolo e uma caixa de phosphoros. 



\section{SUPPLEMENTO N. 42}

TABELlA DE DISTRIBUIÇÃO DIARIA DE GENEROS PARA 6 PESSOAS

Farinha de mandioca. . . . . . $2^{1}, 4$ Feijão . . . . . . . . . . . $\mathrm{I}^{1}, 8$ Arroz . . . . . . . . . . . $\mathrm{I}^{1}, 2$ Assucar . . . . . . . . 600 grs Banha . . . . . . . . 300 " Café em grão . . . . . . . . I 50 " Mate . . . . . . . . . . I00 "

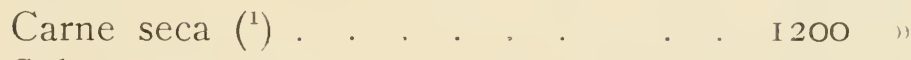
Sal . . . . . . . 0,05 "

Ponte de Pedra em I 3 de Janeiro de igiz. Matto-Grosso.

(1) Preparada no local pelo processo usarlo no Norte (carne de sol). 



\section{SUPPLEMENTO N. 43}

TABELLA DE DISTRIBUIÇÃO DE GENEROS ADOPTADA NO RIO JACY-PARANÁ PELA TURMA DE ExPLORAÇÃO

I) Ao clarear do dia um caneco (volume mais ou menos de 2 chicaras de chá) com café ou chá na falta daquelle, acompanhado de uma mão cheia de bolachas nacionaes d'agua e sal ; sendo o café temperado de assucar, na cozinha, logo depois de coado (regula um pires bem cheio de assucar para cada 8 homens).

2) Almoço á hora em que começa a aquecer o sol (entre I i horas e 30 minutos e I 2 horas e 30 minutos commummente) constando de arroz, feijão, farinha e carne secca (esta é logo picada em tantos pedaços quantas as " etapas a pagar " $\left({ }^{1}\right)$ e cozinha no proprio feijão); quantidades: de feijão uma concha commum bem cheia, arroz concha e meia, de farinha uma chicara de chá rasa.

3) Jantar, á hora que fica sempre em funcção do serviço diario (ao cahir da noite, geralmente), constando dos mesmos generos e quantidades do almoço e mais uma chicara de chá adoçado. militar.

(1) Etapas a pagar ou rações a distribuir, conforme a technologia 


\section{0}

CONSUMO DIARIO

Na turma, quando reduzida a + officiaes e 8 praças, consumia-se diariamente :

600 grammas de assucar.

2 litros de arroz.

+ litros de farinha.

2,5 litros de feijão.

1200 grammas de bolachas.

300 a 400 grammas de banha.

3,75 a 5 kilos de carne seca em lata.

N. B. - A caça substituia muitas vezes a carne seca. 


\section{INDICE}

Introduç̧ão . . $\quad$ • . . . . . . . . . . . . . . 5

Capitulo 1 - Sob a vossa chefia immediata. . . . . . . . 7

Capitulo II - Chefiando uma turma . . . . . . . . . . 16

Capitulo 111 - Serviços de levantamento . . . . . . . . . 53

Capitulo IV - Observações meteorologicas . . . . . . . . 54

Capitulo V-Serviços de geologia e zoolog̣ia . . . . . . . . 57

Capitulo VI-Do contingente . . . . . . . . . . . . . 58

Capitulo VIl - Das tropas e dos tropeiros. . . . . . . . . . 64

Tropa de bois. . . . . . . . . . . . . 74

Capitulo VIll - Ligeira notic a sobre os indios da zona percorrida. . 77

Capitulo IX - Ligeiras notas sobre a vida dos seringaes, por onde passou a $2 .^{\text {a }}$ turma. . . . . . . . . . . 83

Capitulo X--Conclusão . . . . . . . . . . . . . . 88

\section{SUPPLEMENTOS}

N. 1 - Carte dirigida ao Sr. Coronel Rondon em 25-1-1914. . 89

N. ${ }^{\circ} 2$ - Carta dos demissicnarios. . . . . . . . . . . . . 95

N. ${ }^{\circ} 3$-Relação do pessoal superior e alieraç̃̃es duranie a marcha. 97

N. ${ }^{\circ} 4$-Relaçĩo do pessoal de que se compunhá o contingente da $2{ }^{\text {a }}$ turma . . . . . . . . . . . . . . . 99

N. ${ }^{\circ} 5$-Relação do pæssoal da tropa de bois que acompanhou a $2{ }^{3}$ turma da Expedição . . . . . . . . . . 101

N. ${ }^{\circ} 6$-Relação do pessoal da tropa de muares que acompanhou a

$2{ }^{a}$ turma . . . . . . . . . . . . . 103

N. ${ }^{\circ} 7$ - Relaz̃ão do pessoal que acompanhou a tropa de bois do rio da Duvida . . . . . . . . . . . . . . 105

N." 8-Carga e descarga de animaes da 1.a turma . . . . . 107

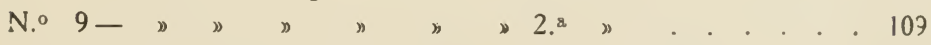

N. ${ }^{\circ} 10-$ Carta do Sr. Coronel Rondon, de 24-1-1914. . . . . 111 
N,o 11 - Marcha do contingente que acompanhou a $2 .^{a}$ turma

N.o 16 - Carta dirigida ao Sr. Coronel Rondon, en 8-2-19/4. . 123

N. ${ }^{\circ} 17$ - Idem ao Tenente Lyra, em 13-2-1914. . . . . . 125

N." 18 -Idem ao Sr. Coronel Rondon, na mesma data. . . . . 127

N." 19 - Idem do Sr. Coronel Rondon, de 11-2-1914. . . . . 131

N. ${ }^{\circ} 20$ - Idem dirigida ao Sr. Coronel Rondon, ainda em !3-2-1914. 133

V.॰ 21 -Idem idem, em 22-2-1914. . . . . . . . . . 135

No 22 - Idem idem, em 23-2-1914. . . . . . . . . . . 139

V.. 23 - Relaşão do pessoal que acompanhou a troba do rio da Duvida e que foi aggregado á 2. ${ }^{\text {a }}$ turma até o acampamenio da Commissão .

Y. 24 - Relação do pessoal que acompanhou o contingente da $1 .{ }^{a}$ turma, e que foi transferido para a $2 .^{a}$ turma, em 27 de Fevereiro de 1914.

N. ${ }^{2} 25$ - Telegramma ao Dr. Lauro Müller, Ministro do Exterior.

N. 26 - Carta ao Tenente Aureliano Coutinho, em 1-3-1914.

N. 27 - Ideni idem . . . . . . . . . . . . . . . . 153

N. ${ }^{\circ} 28$ - Idem ao Tenente Vieira de Mello, em 10-3-1914. . . 155

N. 29 - Idem ao Coronel Rondon, em 16-3-1914. . . . . . 161

N. ${ }^{\circ} 30$-- Idem idem, em 21-3-1914. . . . . . . . . . 169

N.? 31 - Telegramma ao Dr. Lauro Müller, Ministro do Exterior, em 4-4-1914.

N. 32 - Carta ao Coronel Rondon, em 6-4-1914 . . . . . . 173

N. ${ }^{\circ 3}$ - - Idem ao Coronel Theodoro Roosevelt, em 11-4-1914. . 177

N.o 34 - Idem ao Coronel Rondon, em Abril de 1914 . . . . . 179

N.॰ 35-Idem ao Sr. Kermit, em Abril de 1914. . . . . . . 181

N. 0836 a 39 - Mappas ( ${ }^{1}$ ).

N. ${ }^{4} 40$ - Quadro comparativo das rações por praça.

N. ${ }^{\circ} 41$ - Tabellas de generos adoptadas pela Commissão de Linhas

Telegraphicas Estrategicas de Matto-Grosso ao Amazonas. em Tapirapoan, e pela Expedição Scientifica RooseveltRondon .

N. 42 -.- Tabella de distribuição diaria de generos para 6 pessoas.

N. 43 - Idem de distribuição de generos, adoptada no rio Jacy-

Paraná pela turma de exploração

(1) Por nào e-tarem concluidos os desenhos, seráo mais tarde distribuidos os annexus we ns. 36 a 39. 





